Nang Hseng Hom

Pollen Genotype Effects on Seed Quality and Selection of Single Seeds by Near-Infrared Reflectance Spectroscopy (NIRS) in Winter Oilseed Rape

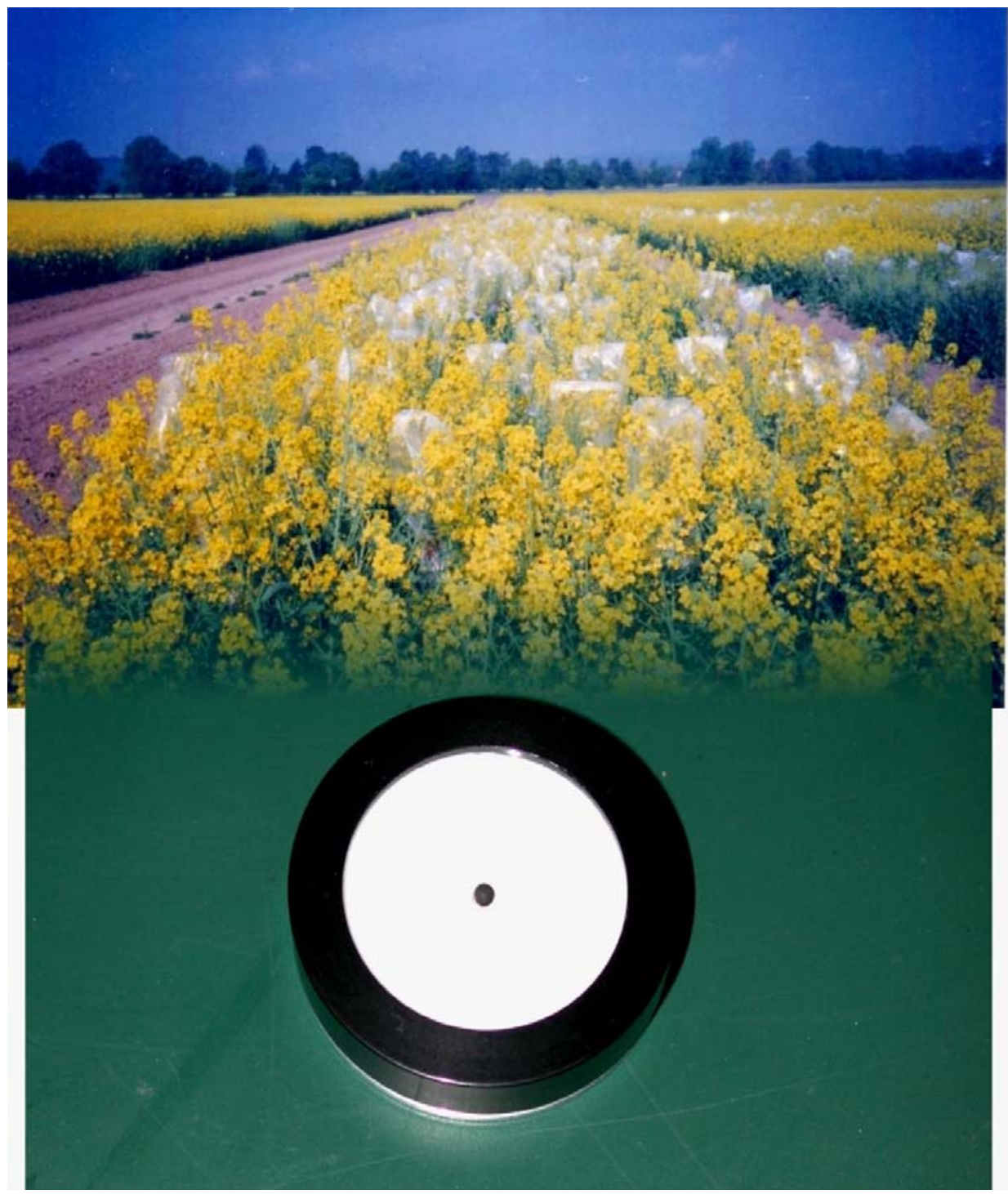




\title{
Pollen Genotype Effects on Seed Quality and Selection of Single Seeds by Near-Infrared Reflectance Spectroscopy (NIRS) in Winter Oilseed Rape
}

\author{
Doctoral Dissertation \\ Submitted for the degree of Doctor of Agricultural Sciences \\ of the Faculty of Agricultural Sciences \\ Georg-August University of Göttingen \\ Germany
}

by

Nang Hseng Hom

Born in Kyaukme, Myanmar

Göttingen, July 2004 
D 7

Referee:

Prof. Dr. Heiko C. Becker

Co-referee:

Prof. Dr. Elke Pawelzik

Date of oral examination:

15 July 2004

„Gedruckt mit Unterstützung des Deutschen Akademischen Austauschdienstes“ (Printed with the support of the German Academic Exchange Service) 


\section{Table of Contents}

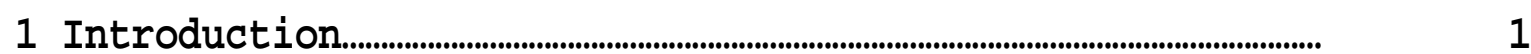

2 Literature Review.............................................................................

2.1 Biochemistry of oilseed rape quality......................................... 3

2.1.1 Lipids and fatty acids......................................................................

2.1.2 Protein ................................................................................................................

2.1.3 Glucosinolates...............................................................................

2.1.4 Sinapic acid esters..............................................................................

2.1.5 Tocopherols....................................................................................................... 11

2.2 Genetics of oilseed rape quality .................................................. 14

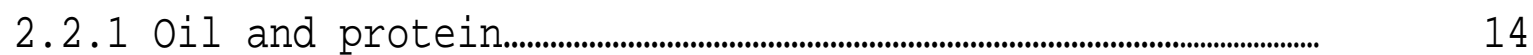

2.2.2 Fatty acids....................................................................................

2.2.3 Glucosinolates...............................................................................................

2.2.4 Sinapic acid esters.............................................................................. 21

2.2 .5 Tocopherols.................................................................................................

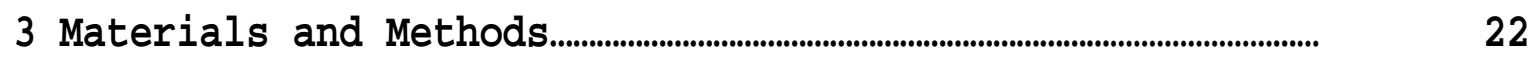

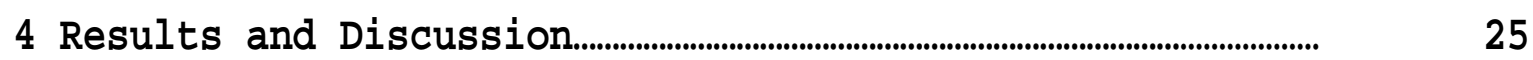

4.1 which seed quality traits are influenced by pollen genotype effects?............................................................................... 25

4.2 Is increased oil content related with high erucic acid content?........................................................................................... 28

4.3 Is it possible to select for quality of individual $F_{2}$ seeds by using near-infrared reflectance spectroscopy (NIRS)?

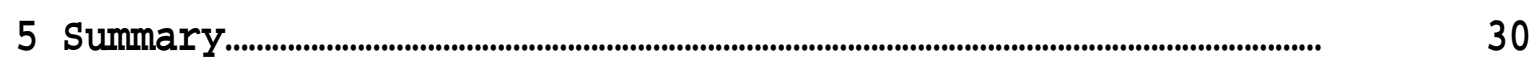

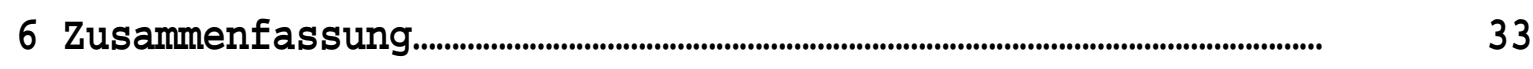

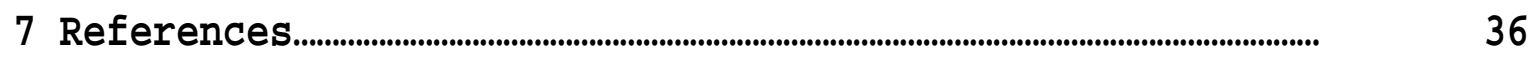

The following manuscripts in the appendix are part of this thesis:

I. Pollen genotype effects on seed quality traits in winter oilseed rape

II. Non-destructive analysis of oil, protein and glucosinolate content in single seeds of oilseed rape by near-infrared reflectance spectroscopy(NIRS)

III. Selection for oil, protein and glucosinolate content of individual $F_{2}$ seeds in winter oilseed rape 


\section{Introduction}

Oilseed rape is the most important source of vegetable oil in Europe and the second most important oilseed crop on the international oilseed market after soybean. Genetic improvement of the seed quality made oilseed rape a source for a high quality, edible oil for human consumption and high quality protein meal for feeding animals. Present "double-low" or "canola" cultivars contain less than $2 \%$ erucic acid and less than $25 \mu \mathrm{mol} / \mathrm{g}$ glucosinolates in air dry seed. Even though, the improving of the quality is still going on. Different quality characteristics are required for the use of the seed for non-edible products, such as detergents, lubricants, cosmetics, hydraulic oils, or biodiesel (Shahidi, 1990; Kimber and McGregor, 1995). To fulfil all future requirements, improvement of the seed quality is one of the most important objectives in rapeseed breeding (Becker et al., 1999).

The functional and nutritional values of different vegetable oils are dependent on the nature of the different fatty acids which are incorporated into the oil (triacylglycerols). The "double-low" oilseed rape has a perfect fatty acid composition as salad oil, high in oleic acid and in essential polyunsaturated fatty acids. Further oil quality improvements include the development of very high oleic/low linolenic acid cultivars for use in frying applications, and the selection for low and very low (zero) content in saturated fatty acids for certain markets (Rakow and Raney, 2003).

On the other hand, high erucic acid oilseed rape cultivars are regaining interest for industrial purposes. Moreover, vitamin E and antioxidant properties of $\alpha$-tocopherol and $\gamma$-tocopherol in oilseed rape also play an important role. After oil extraction, the remaining meal contains different nutritional and antinutritional compounds. Among them, glucosinolates and sinapic acid esters are the most important antinutritional compounds. The glucosinolates are nitrogen and sulphur containing natural plant products that have become increasingly important as flavour precursors, cancerprevention agents, and crop protectants (Graser et al., 2000). If the content of sinapic acid esters is more than $1 \%$ in seeds, it is believed to limit use of oilseed rape meal as a source of high-quality protein for food production (Zum Felde et al., 2003). Genetics and inheritance of seed quality traits such as oil, protein, fatty acids, antinutrient glucosinolate and sinapic acid esters, and vitamin $E$ and natural 
antioxidant tocopherols ( $\alpha$-tocopherol and $\gamma$-tocopherol) must be well understood for an efficient selection of seed quality improvement.

The fatty acid composition is well-known to be determined by the genotype of the embryo. It is often assumed, that most other oilseed rape quality traits like oil, protein and glucosinolate contents are only determined by the genotype of the mother plant and not influenced by the genotype of the pollinator. However, experimental knowledge on the pollen influence on other seed quality traits is very limited.

If the pollinator genotype is of influence on the individual seed quality, this could allow to select already among individual $F_{2}$ seeds by applying single seed nearinfrared reflectance spectroscopy (NIRS).

The overall aim of the present study is to analyse the influence of pollen effects on seed quality traits and to investigate the possibility of using NIRS for selection among single seeds. The specific objectives are

-to determine the pollen genotype effect on seed quality

-to evaluate the seed genetic effects (direct seed or dominance seed effects) controlled by diploid embryo nuclear genes, cytoplasmic effects controlled by cytoplasmic genes which showed the maternal gene in embryo and maternal genetic effects (maternal additive or dominance effects) on seed quality

-to study the possibility of using NIRS to predict the oil, protein, and glucosinolate contents of single seeds

-to test whether a selection of single seeds in $F_{2}$ is efficient, and -to determine whether increasing oil content is related with high erucic acid content. 
2 Literature Review

\subsection{Biochemistry of oilseed rape quality}

\subsubsection{Lipids and fatty acids}

A plant stores reserve material (oil, protein, and carbohydrate) in its seed to allow growth of the next generation. Lipids are the major form of carbon storage in the seeds of many plants species. The chemical form in which oil stored in seed is a triacylglycerol (TAG), which has a three carbon glycerol backbone and fatty acids esterified at each of the three positions.

In the mature seed, TAG is stored in densely packed lipid bodies that are roughly spherical in shape and possess diameters ranging from 0.5 to $2.5 \mu \mathrm{m}$ (Huang, 1992; Murphy 1993; Herman, 1995). The size does not change during seed development, and accumulation of oil is accompanied by an increase in the number of lipid bodies (Ohlrogge and Browse, 1995). Oil bodies are degraded during germination and cotyledon senescence to mobilise stored TAG (Thompson et al., 1998). Lipases are synthesized and may associate with oil bodies during germination (Huang, 1992). It has therefore been suggested that oleosin may contain a binding site for lipases or be a lipase activator (Huang, 1992; Murphy and Vance, 1999).

The reactions for de novo fatty acid synthesis (FAS) are located in plastids (Ohlrogge et al., 1979), which are plant-specific organelles bound by an envelope double membrane, and uses acyl -ACPs ( acyl carrier protein) as substrates. In addition, the further modifications (desaturation, hydroxylation, elongation and esterfication of oleate to complex lipids ) occur in the cytosol, mainly in the endoplasmic reticulum (ER) while acyl chains are esterified to glycerolipid or CoA.

The enzymatic pathways of fatty acids are as follows: first, sucrose is broken down to acetyl-CoA, which enters the acyl carrier protein (ACP) track and is converted to palmitate (C16:0) by fatty acid synthase. Fatty acids are built from 2-C units derived from acetyl-CoA and acetate units are activated for transfer to growing fatty acids chain by conversion to malonyl-CoA. Then, six molecules of malonyl CoA and one molecule of acetyl CoA interact sequentially with fatty acid synthase to yield the final product, palmitate $(\mathrm{C} 16: 0)$. The palmitate is elongated to stearate $(\mathrm{C} 18: 0)$ by soluble elongase and stearate is desaturated to oleate $(C 18: 1)$ by a soluble $\delta-9$ desaturase. 
This de novo synthesis of fatty acids occurs in the soluble portion of plastids. The elongation of fatty acids in the plastids is terminated when the acyl group is removed from acyl carrier protein (ACP) (Ohlrogge and Browse, 1995).

After that the desaturation and esterification of oleate to complex lipids occurs in the endoplasmic reticulum. In Arabidopsis as well as in oilseed rape, C18:1 is further desaturated by a $\delta$-12-desaturase to form $\mathrm{C} 18: 2$ and the presence of $\delta$-15-desaturate is needed to desaturase C18:2 to C18:3 (Okuley et al., 1994). Furthermore, the oleic acid in form of $\mathrm{C} 18: 1-\mathrm{CoA}$ might also be sequentially elongated first to eicosenoic acid (C20:1) and then to erucic acid (C22:1).

\subsubsection{Protein}

Only two proteins associated with oil bodies have been described, oleosin and caleosin (Frandsen et al. 2001). Oleosin is thought to be important for oil body stabilisation in the cytosol, although neither the structure nor the function of oleosin has been fully elucidated. The early stage of oilseed rape embryo development is characterised by starch accumulation. With the onset of oil and storage protein deposition, this starch is degraded (Da Silva et al., 1997). The starch accumulation and energy supply alter oil content in rape seeds (Martini et al. 1999).

The storage proteins are of particular importance because they determine not only the total protein content of the seed but also its quality for various end uses. All storage proteins have a number of common properties. First, they are synthesized at high level in specific tissues and at certain stages of development. Their synthesis is depending on nutrient availability, and they act as a sink for surplus nitrogen. A second common property of seed storage proteins is their presence in the mature seed in discrete protein bodies. All storage protein fractions are mixtures of components that exhibit polymorphism both within single genotypes and among genotypes of the same species (Shewry et al., 1995).

The endoplasmic reticulum (ER) is the gateway to the secretory pathway, and the proteins that are made and assembled in the ER can have a variety of cellular destinations (Vitale and Denecke, 1999). In most instances proteins move directly to the Golgi system within minutes after being synthesized, but some proteins and other molecules can apparently be stored for shorter or longer periods of time in ER- 
derived compartments. In some cases these ER-derived compartments are transported to and are incorporated into vacuoles. Plant cells appear to have flexibility in using the ER to assemble storage organelles. A role for the ER in vacuole ontogeny in storage tissues of young seedlings by forming small "second vacuoles" (precursor protease vesicles, PPVs) that are involved in the mobilization of proteins in the protein storage vacuoles (PSVs) was described by Chrispeels and Herman (2000).

To date, there have been no large-scale studies on the timing of expression of multiple genes from different biosynthetic pathways in developing seeds. During early embryogenesis, when the tissues and organelles are established, carbon and other nutrients are used mainly for rapid cell division and embryo growth. After the cessation of cell division, during the maturation phase, resources are allocated to synthesize storage compounds. In Arabidopsis, this maturation phase is characterized by a transient accumulation of starch, followed by major increases in the oil and protein contents. During the subsequent late maturation and desiccation phases, the overall biosynthetic activity decreases as the seed prepares for dormancy (Mansfield and Briarty, 1991; Harada, 1994).

\subsubsection{Glucosinolates}

Glucosinolates are a large group of plant secondary metabolites found mainly in the order Capparales, which includes a large number of economically important Brassica crops and the model plant Arabidopsis. They are characterised by having a thioglucose moiety, a sulfonated oxime, and a side chain $\mathrm{R}$ derived from aliphatic, aromatic, and indole amino acids (Mikkelsen et al., 2000). The general structure of glucosinolates is shown in Figure 1.

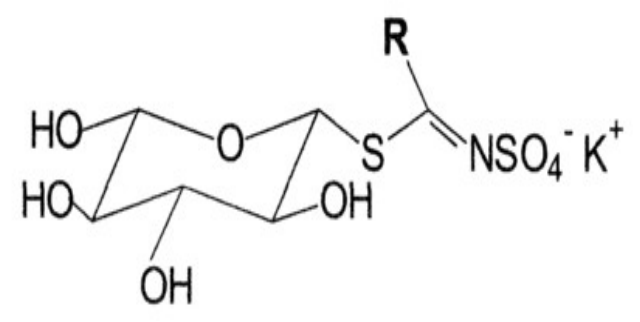

Figure 1. General structure of glucosinolate $(R=$ functional group) (adopted from Linsinger et al., 2001). 
The structure of the side chain $\mathrm{R}$ of the major glucosinolates occurring in the Brassicaceae is described in Table 1. There are many types of side chain, $\mathrm{R}$, ranging from simple alkyl chains to heterocyclic side chains. The seeds of Brassica napus primarily stores progoitrin (Röbbelen and Thies, 1980). Over 100 side chains, and thus glucosinolates, have been identified (Sørensen, 1991). They are found in all plant parts, but their quantities may vary considerably among organs (Kjaer, 1976). Glucosinolates are localized in the vacuole within the cell (Halkier and Du, 1997).

Table 1. Structure of the side chain $R$ of the major glucosinolates occuring in the Brassicaceae (adopted from Bjerg and Sørensen, 1987).

\section{Structure of $\mathbf{R}$}

Aliphatic glucosinolates

$\mathrm{CH}_{2}=\mathrm{CH}-\mathrm{CH}_{2}-$

$\mathrm{CH}_{2}=\mathrm{CH}-\mathrm{CH}_{2}-\mathrm{CH}_{2}-$

$\mathrm{CH}_{2}=\mathrm{CH}-\mathrm{CH}_{2}-\mathrm{CH}_{2}-\mathrm{CH}_{2}-$<smiles>C=CC([CH2-])O</smiles>

$\mathrm{CH}_{2}=\mathrm{CH}-\mathrm{CH}_{2}-\mathrm{CH}-\mathrm{CH}_{2}-$

$\mathrm{CH}_{3}-\mathrm{SO}-\mathrm{CH}_{2}-\mathrm{CH}_{2}-\mathrm{CH}_{2}-$

$\mathrm{CH}_{3}-\mathrm{SO}-\mathrm{CH}_{2}-\mathrm{CH}_{2}-\mathrm{CH}_{2}-\mathrm{CH}_{2}-$

Aromatic glucosinolates $\left(\mathrm{C}_{6} \mathrm{H}_{5}\right)-\mathrm{CH}_{2}-\mathrm{CH}_{2}-$

Indole glucosinolates<smiles>[R4]c1cccc2c1c(CC)cn2[R]</smiles>

Chemical name

2-propenyl-or allyl glucosinolate

but-3-enyl glucosinolate

pent-4-enyl glucosinolate

2-hydroxybut-3-enyl glucosinolate

2-hydroxypent-4-enyl glucosinolate

3-methylsulfinylpropyl glucosinolate

4-methylsulfinylbutyl glucosinolate

2-phenethyl glucosinolate

indol-3-ylmethyl glucosinolate

$\left(R_{1}=R_{4}=H\right)$

1-methoxyindol-3-ylmethyl glucosinolate $\left(\mathrm{R}_{1}=\mathrm{OCH}_{3} ; \mathrm{R}_{4}=\mathrm{H}\right)$

4-hydroxyindol-3-ylmethyl glucosinolate $\left(\mathrm{R}_{1}=\mathrm{H} ; \mathrm{R}_{4}=\mathrm{OH}\right)$

4-methoxyindol-3-ylmethyl glucosinolate $\left(\mathrm{R}_{1}=\mathrm{H} ; \mathrm{R}_{4}=\mathrm{OCH}_{3}\right)$

\section{Trivial name}

Sinigrin

Gluconapin

Glucobrassicanapin

Progoitrin

Gluconapoleiferin

Glucoiberin

Glucoraphanin

Gluconasturtiin

Glucobrassicin

Neoglucobrassicin

4-Hydroxyglucobrassicin

4-Methoxyglucobrassicin 
Hydrolysis of the glucosinolates occurs when the seeds are crushed and when moisture is present, myrosinases catalyse the hydrolytic cleavage of the thioglucosidic bond, giving D-glucose and an unstable thiohydroximate-O-sulphate which on release of sulphate (via a Lossen rearrangement) can result in the production of isothiocyanates, nitriles and elementary sulphur (Bones and Rossiter, 1996) (Figure 2).

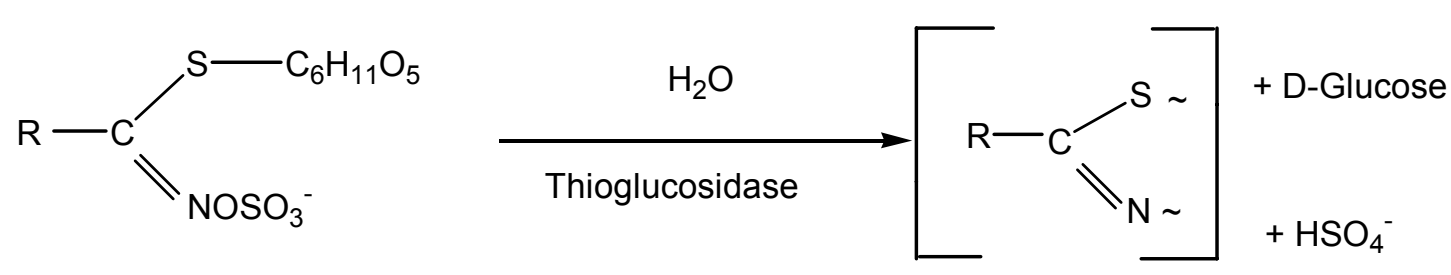

Alkenyl glucosinolate

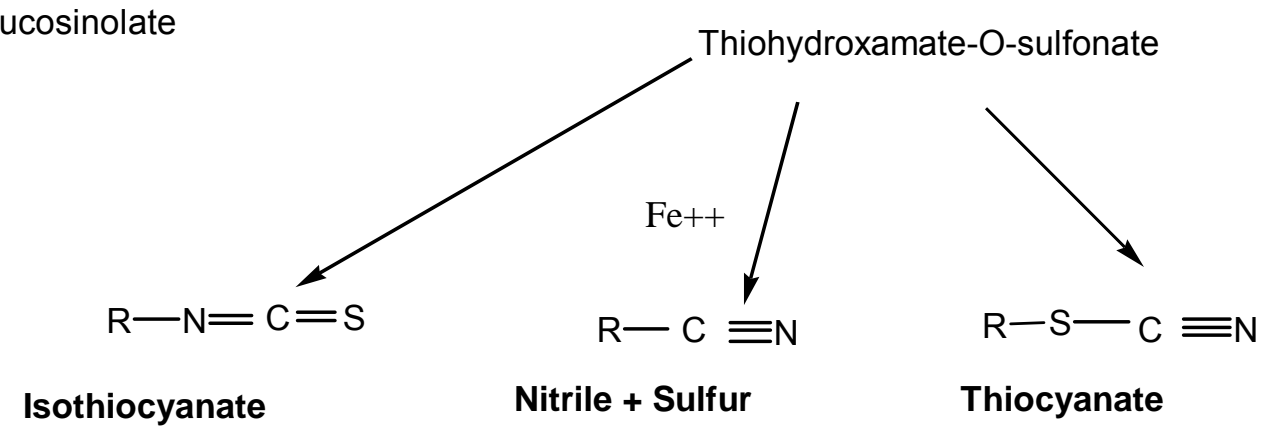

Figure 2. Hydrolysis of alkenyl glucosinolates (adopted from Rosa, 1999).

The predominant product is dependent on several variables such as the $\mathrm{pH}$; temperature, concentration of $\mathrm{H}^{+}$, nature of the glucosinolate side chain and presence of certain cofactors such as ferrous iron (MacLeod and Rossiter, 1987; Uda et al., 1986; Bones et al., 1994).

The $\mathrm{pH}$ 5-7 aliphatic side chains tend to produce isothiocyanates, whereas at more acidic $\mathrm{pH}$, nitriles rather than isothiocyanates are formed. Since isothiocyanates have more significant organoleptic, biological and plant protective roles it is clear that the $\mathrm{pH}$ at which hydrolysis occurs is important (Rosa, 1999).

The products of glucosinolate hydrolysis include isothiocyanates, thiocyanates and nitriles (Chubb, 1982). These compounds often contribute to a bitter, "hot" taste to condiments and may exhibit goitrogenic or antithyroid activity. Isothiocyanates have a strong antitumourogenic effect, and help protect against cancers of the lungs and alimentary tract in humans (Johnson, 2002). Glucosinolates are also natural products 
that function in the defence toward herbivores and pathogens (Mikkelsen et al., 2003).

The isothiocyanates also give rise to the most actively goitrogenic compounds by being cyclized to form oxazolidone-2-thiones (Chubb, 1982). The most goitrogenic compound is 5-vinyl-oxazolidone-2-thione, commonly known as goitrin. The glucosinolate that gives rise to goitrin is 2-hydroxy-3-butenyl glucosinolate or progoitrin (Chubb, 1982). This is the predominant glucosinolate in oilseed rape, representing between 50 and $70 \%$ of the total glucosinolate concentration (Zhao et al., 1994).

Glucosinolates with an aliphatic side chain substituted at carbon 2 with a hydroxyl group produce unstable isothiocyanates which cyclize spontaneously to form oxyzolidine-2-thiones, compounds with irreversible goitrogenic or antithyroid activity (Rosa, 1999). Compounds with indolic or substituted indolic side chains also produce unstable isothiocyanates which in turn give rise to the corresponding indole-3carbinol and thiocyanate ion (Searle et al., 1982).

Under acidic conditions the production of nitriles is favoured and during autolysis nitriles tend to be produced even at unfavourable $\mathrm{pH}$, probably due to the inhibitory effect of ferrous iron isothiocyanate formation (Uda et al., 1986).

Moreover, when the $\mathrm{R}$ side chain has a terminal unsaturated group, the presence of ferrous iron together with epithiospecifier protein, results in the formation of episulphides (MacLeod and Rossiter, 1985; Petroski and Kwolek, 1985).

There are three different stages characterising the biosynthesis of glucosinolates:

1. The synthesis of chain-elongated amino acids: the amino acid may enter the chain elongation pathway, in which the condensing enzymes MAM1 and MAM-L have recently been identified (De Quiros et al., 2000; Kroymann et al., 2001);

2. The core glucosinolate structure is formed: the aldoxime-metabolizing enzymes are cytochromes P450 belonging to the CYP83 family (Bak et al., 2001; Hansen et al., 2001). CYP83 A1 is metabolising the aliphatic aldoximes, where CYP83B1 metabolises the indole and aromatic aldoximes (Bak and Feyereisen, 2001). The 
least well understood step in the glucosinolate pathway is the conversion of oxime to thiohydroximate. Thiohydroximate is S-glucosylated to desulfoglucosinolate via an uridine-diphospho-glucose (UDPG) thiohydroximate glucosyltransferase, an enzyme that has been isolated from oilseed rape (Brassica napus) (Reed et al., 1993). Moreover, the candidate Arabidopsis UDP-Glc:S-thiohydroximic acid glucosyl transferase (S-GT) has been identified (Petersen et al., 2002) based on homology to a putative Brassica sp. S-GT (Marillia et al., 2001).

3. The side chain modifications: the initially formed glucosinolate can undergo a variety of subsequent transformations that modify the side chain. These side-chain modifications are specific for the precursor amino acid utilized in the formation of the chain-elongated Met-derived glucosinolates, which are the major glucosinolates in Arabidopsis and many other Brassicaceae species (Kliebenstein et al., 2001).

\subsubsection{Sinapic acid esters}

Sinapic acid esters are important antinutritional factor compounds of the seeds of oilseed rape and related Brassica species. Among them, the choline ester of sinapic acid which is sinapoylcholine or sinapine (Figure 3 ) is the most abundant. The sinapoylglucose and sinapoylmalate are also the components of sinapic acid esters (Figure 4). The total content of sinapic acid esters in oilseed rape meal ranges from 6.2 to $12.8 \mathrm{~g} \mathrm{~kg}^{-1}$ dry weight (Shahidi and Naczk, 1992).<smiles>COc1cc(/C=C/C(=O)O)cc(OC)c1O</smiles>

C00482

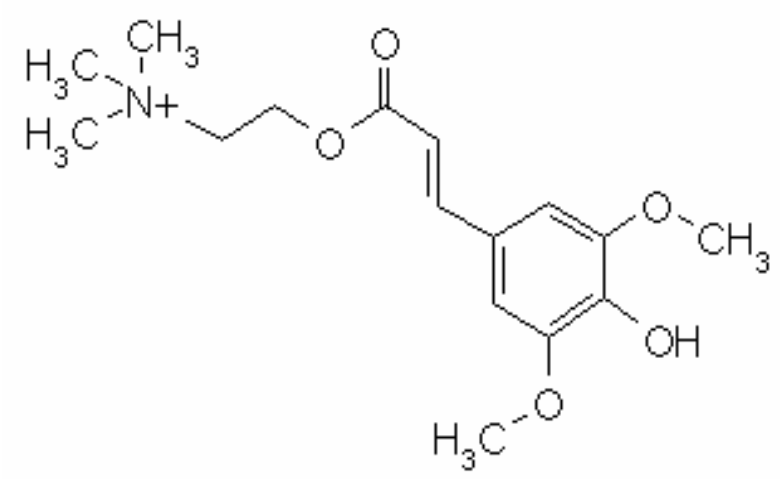

C00933

Sinapic acid (sinapate)

Sinapoylcholine or sinapine

Figure 3. The structures of sinapic acid and the choline ester of sinapic acid (sinapoylcholine or sinapine). 
<smiles>COc1cc(/C=C/C(=O)O)cc(OC)c1O[C@@H]1O[C@H](CO)[C@@H](O)[C@H](O)[C@H]1O</smiles>

C02919

Sinapoylglucose<smiles>COc1cc(/C=C/C(=O)O)cc(OC)c1OC(=O)[C@@H](O)CC(=O)O</smiles>

C02887

Figure 4. The structures of sinapoylglucose and sinapoylmalate.

Sinapine is generally only an issue for feeding poultry because it is fermented by bacteria in the ceca to trimethylamine. This is absorbed and converted to trimethylamine oxide, which is excreted in the eggs. The result is a fishy odour in egg (Fenwick et al., 1981). Sinapic acid (sinapate) and sinapine are derived from the general phenylpropanoid pathway (Whetten et al., 1998). Arabidopsis and some other members of the Brassicaceae accumulate three major sinapic acid esters.

In the biosynthetic pathway leading to these compounds, sinapoylglucose is the immediate precursor of sinapoylcholine or sinapine and sinapoylmalate, which accumulate in seeds and leaves, respectively. The enzymes required for the conversion of phenylalanine to sinapic acid are phenylalanine ammonia-lyase (PAL), cinnamate 4-hydroxylase $(\mathrm{C} 4 \mathrm{H}), p$-coumarate 3 -hydroxylase $(\mathrm{C} 3 \mathrm{H})$, caffeic acid/5hydroxyferulic acid O-methyltransferase (OMT), and ferulate 5-hydroxylase (F5H). The enzymes unique to sinapate ester biosynthesis are UDP-glucose: sinapic acid glucosyltransferase (SGT), sinapoylglucose:malate sinapoyltransferase (SMT), sinapoylglucose:choline sinapoyltransferase (SCT), and sinapoylcholinesterase (SCE) (Figure 5). 
Phenylalanine

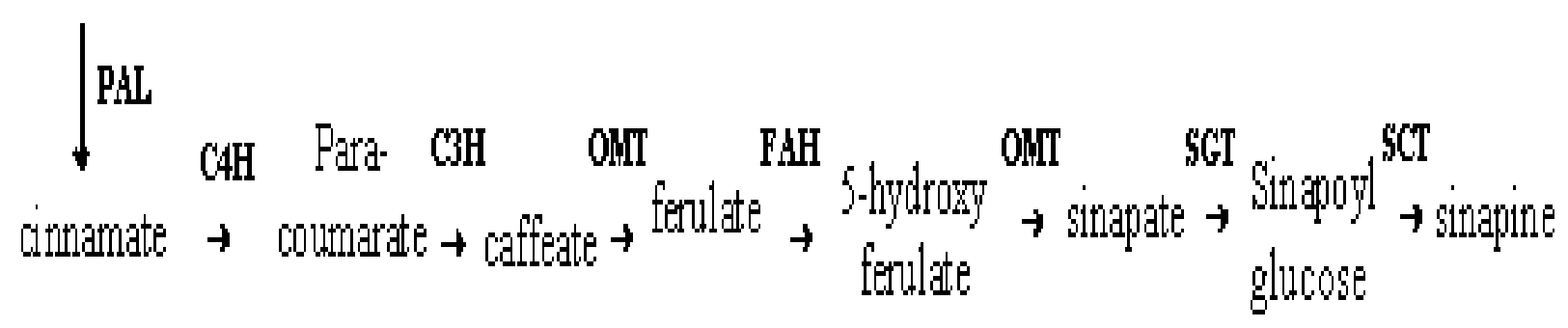

Figure 5. The biosynthetic pathway of sinapic acid esters (adopted from Selvaraj et al., 1999).

During seed maturation, however, sinapoylglucose is converted to sinapoylcholine by sinapoylglucose: choline sinapoyltransferase (SCT) (Strack et al., 1983). The identification of an Arabidopsis mutant, sng 1 (sinapoylglucose accumulator 1 ), that is defective in synthesis of sinapolymalate, one of the major phenylpropanoid secondary metabolities accumulated by Arabidopsis and some other members of the Brassicaceae was reported (Lehfeldt et al., 2000).

\subsubsection{Tocopherols}

Tocopherols are the most powerful natural fat-soluble antioxidants in vegetable oils. They are synthesized by photosynthetic organisms, which include plants and certain eukaryotic algae where they are synthsized in the plastids, as well as photosynthetic prokaryotes such as blue-green algae (Savidge et al., 2002).

Four types of tocopherols ( $\alpha, \beta, \gamma$, and $\delta$ tocopherols) differ only in the position and number of methyl groups (Figure 6 ). Natural tocopherols and all have three chiral centers, and each has an R-configuration (e.g., natural $\alpha$-tocopherol is $2 \mathrm{R}, 4^{\prime} \mathrm{R}, 8^{\prime} \mathrm{R}$ $\alpha$-tocopherol) (Stone and Papas, 1997). Among the tocopherol components, $\alpha-$ tocopherol has an important role as vitamin $\mathrm{E}$ and $\gamma$-tocopherol has an antioxidant effect during storage.

The predominant form in the leaves of higher plants is $\alpha$-tocopherol, whereas in seeds $\gamma$-tocopherol is often the major isoform (Tan, 1989; Demurin et al., 1996). Plant oils, the main dietary source of tocopherols, typically contain $\alpha$-tocopherol as a minor component and high levels of its biosynthetic precursor, $\gamma$-tocopherol (Shintani and DellaPenna, 1998). 
In oilseed rape, total tocopherol content ranges from 300 to $800 \mathrm{mg} \mathrm{kg}^{-1}$ oil (Goffman and Becker, 2001) and total tocopherol contents as plot mean values showed a broad range from about $350-1000 \mathrm{ppm}$ in oil and $\alpha / \gamma$ tocopherol ratio varied from 0.53 to 1.70 (Marwede et al., 2003).<smiles>[R]c1c([R])c2c(c([R])c1O)CC[C@@](C)(CCC[C@H](C)CCC[C@H](C)CCCC(C)C)O2</smiles>

\begin{tabular}{cccc}
\hline & $\mathrm{R}_{1}$ & $\mathrm{R}_{2}$ & $\mathrm{R}_{3}$ \\
\hline Tocol & $\mathrm{H}$ & $\mathrm{H}$ & $\mathrm{H}$ \\
\hline$\delta$-Tocopherol & $\mathrm{H}$ & $\mathrm{H}$ & $\mathrm{CH}_{3}$ \\
$\gamma$-Tocopherol & $\mathrm{H}$ & $\mathrm{CH}_{3}$ & $\mathrm{CH}_{3}$ \\
$\beta$-Tocopherol & $\mathrm{CH}_{3}$ & $\mathrm{H}$ & $\mathrm{CH}_{3}$ \\
$\alpha$-Tocopherol & $\mathrm{CH}_{3}$ & $\mathrm{CH}_{3}$ & $\mathrm{CH}_{3}$ \\
\hline
\end{tabular}

Figure 6. The structure of natural RRR-tocopherols (adopted from Savidge et al., 2002).

Epidemiological and experimental studies suggest that antioxidants like vitamin $E$ ( $\alpha$ tocopherol) may play an important role in prevention of chronic disease. Several observational surveys have linked populations with a large intake of vitamin E with reduced incidence of heart disease. These observations have been strengthened by the demonstration of strong antioxidant activity by vitamin $\mathrm{E}$ in cellular, molecular and animal experiments. These results have highlighted a potential role for vitamin $\mathrm{E}$ supplementation in the prevention of chronic disease in humans (Dutta and Dutta, 2003). Nowadays, the focus on $\gamma$-tocopherol is because of its potential role in reducing the risk of prostate cancer (Huang et al., 2003). 
Tocopherols are generated from the condensation of phytylpyrophosphate and homogentisic acid (HGA), followed by cyclization and methylation reactions. The first step in biosynthesis is a prenyltransferase reaction, which is performed by a homogentisate phytyltransferase (HPT) and subsequent cyclization and methylation reactions result in the formation of the four major tocopherols (Figure 7) (Savidge et al., 2002).

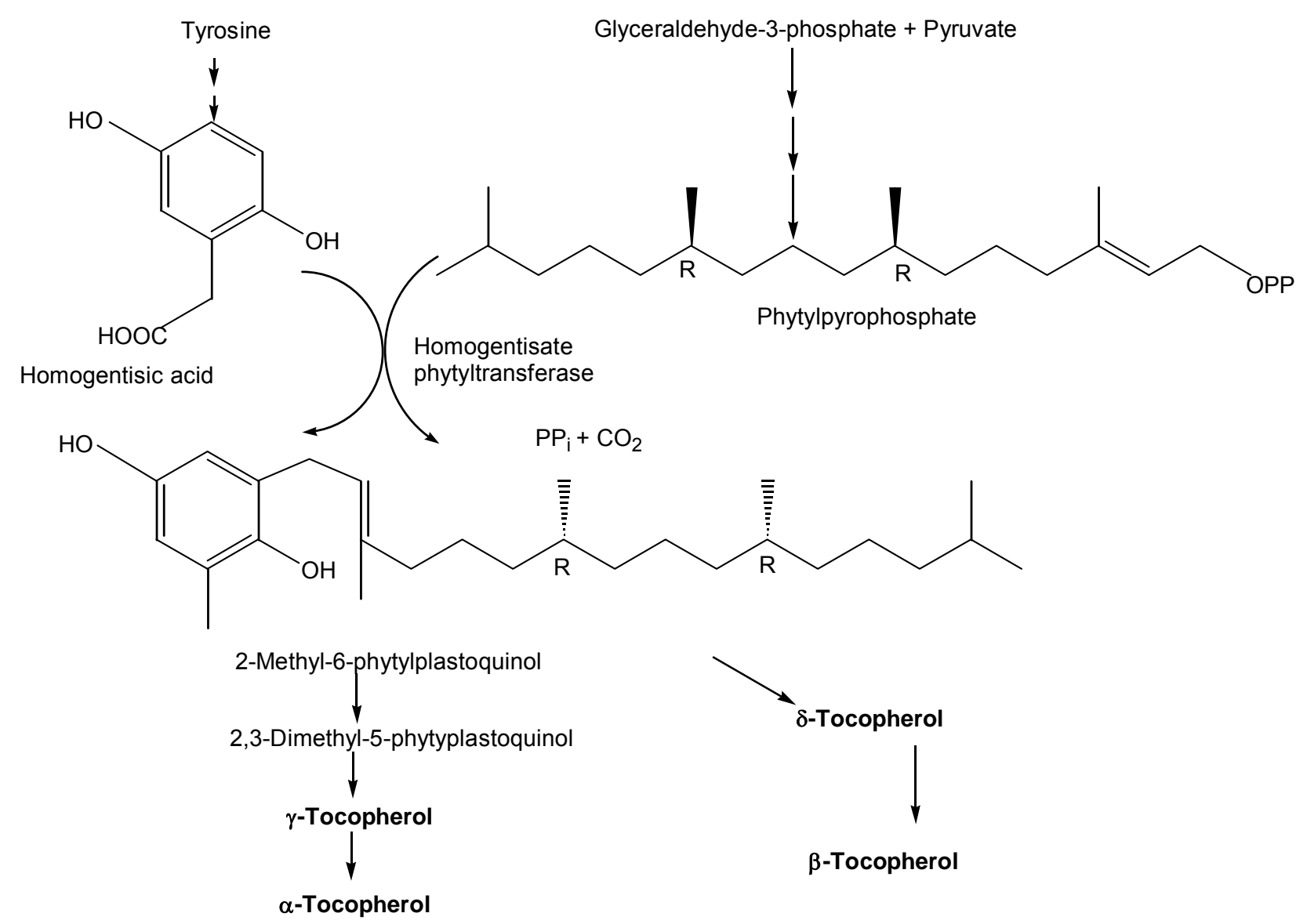

Figure 7. Tocopherol biosynthesis pathway (adopted from Savidge et al., 2002).

Tocopherol biosynthesis takes place in the plastid and the enzymes are associated with the chloroplast envelope (Soll et al., 1980, 1985). The first enzymes cloned in the tocopherol pathway, $\gamma$-tocopherol methyl transferase $(\gamma$-TMT), was identified in Synechocystis sp. PCC 6803 and Arabidopsis (Shintani and DellaPenna, 1998). 


\subsection{Genetics of oilseed rape quality}

\subsubsection{Oil and protein}

Genetic control of oil, protein, and sum of oil and protein contents as a percentage of the seed was investigated in two spring oil seed rape (Brassica napus L.) cultivars, 'Midas' and 'Tower', and their $F_{1}, F_{2}$ and backcross generations. All three traits were shown to be governed by additive gene action, dominance and epistasis were not significant (Grami et al., 1977).

Paternal and maternal effects on oil and protein contents in spring oilseed rape were compared among self and cross pollinated seeds from the same cultivars suggesting that oil and protein contents of seed were determined by the genotype of the mother plant, but pollen source also appeared to have a slight effect on oil content. Comparisons among seed samples produced by the $F_{1}$ and $F_{2}$ progenies, derived from reciprocal crosses, indicated that those traits were controlled by nuclear genes and not by extranuclear factors (Grami and Stefansson, 1977a). Moreover, regression and correlation coefficients between oil content (\%) and protein content (\%) were all negative and highly significant for all populations (parents, $F_{1}, F_{2}$ and backcrosses) (Grami and Stefansson, 1977b).

Some reports mentioned that additive effects are more important genetic factors and additive by environment interaction is significant for oil content (Röbbelen and Thies, 1980; Engqvist and Becker, 1991; Zhao, 2002). In spite of several environmental factors like temperature and mineral fertilisation, oil content is a relatively stable quality trait with high heritability (Becker et al. 1999).

To better understand the genetic basis of oil content in B. napus, QTLs with additive and epistatic effects as well as their interactions with environments were estimated using a mixed model approach (Zhao, 2002). A total of 282 doubled haploid (DH) lines were developed from the $F_{1}$ between the old German cultivar 'Sollux' and the Chinese landrace 'Gaoyou' and a linkage map including 125 SSR marker loci was constructed. The $\mathrm{DH}$ lines were grown in 4 environments, two each in Germany and two in China. It was reported that oil and protein contents in the seed share large part of their genetic basis. However, it is possible to combine high content of seed oil with high meal protein content. Four of seven additive QTLs and two of six pairs of 
epistatic loci for meal protein were not affected by oil content and thus seed oil and meal protein showed much less genetic overlapping that seed oil and seed protein.

In maize, Letchworth and Lambert, 1998 reported the effects of male and female parents on kernel oil, protein, and starch concentration. Twelve maize hybrids were evaluated during 1992 and 1993 in a randomized complete block design with a factorial treatment arrangement ( 2 pollination treatments $\times 12$ hybrids) with two replications grown at each of three locations. The hybrids were grown under openpollinated (OP) and self-pollinated (SP) conditions to determine the pollen source effects on kernel oil, protein and starch contents, SP kernels were higher in protein content than OP kernels but hybrid rank did not change within pollination treatments. Evaluation of reciprocal crosses indicated a strong maternal effect for protein concentration and no pollen effect. Oil concentration was significantly higher in OP kernels than in SP kernels. Significant differences among hybrids for oil concentration indicated a maternal effect, and data from reciprocal crosses indicated a pollen effect. Open-pollinated kernels were higher in starch concentration than SP kernels. Reciprocal crosses indicated a maternal effect for starch concentration and no pollen effect.

In indica rice, analysis of genetic effects on nutrient quality traits indicated that protein content and protein index were mainly affected by seed direct effects. Additive genetic effects were much more important than dominance effects for all traits studied, so that selection could be applied for these traits in early generations (Shi et al., 1996).

\subsubsection{Fatty acids}

Since oilseed rape is an allotetraploid (amphidiploid, $2 n=38$ ) hybrid derived from two species (B. rapa and B. oleracea), the erucic acid (C22:1) content in it is controlled by at least two genes. For erucic acid content up to $30 \%$ the alleles showed additive effect, while at higher concentration partial dominance was common (Jönsson, 1977).

Downey and Craig (1964) and Harvey and Downey (1964) concluded that the fatty acid composition in oilseed rape (B. napus) is conditioned by the genotype of the seed and not by that of the mother plant and that the erucic acid (C22:1) content was 
controlled by two additive genes without dominance. The findings were verified by Kondra and Stefansson (1970) who found that the synthesis of both erucic acid and eicosenoic acid (C20:1) is controlled by the same genes and that these have additive effects with regard to the erucic acid content but dominance effects with regard to the eicosenoic acid content. That the erucic acid (C22:1) content in $B$. napus is inherited by two genes which act in additive gene action was also reported by other authors (Stefansson and Hougen, 1964; Ecke et al., 1995; Lühs and Friedt, 1995). At least five alleles governed the erucic acid level in Brassica, including $e, E^{a}, E^{b}, E^{c}, E^{d}$ which account for $<1 \%, 10 \%, 15 \%, 30 \%$ and $35 \%$ erucic acid respectively (Siebels and Pauls, 1989). Thus, erucic acid can be fixed at a large number of values ranging from $<1 \%$ to $>60 \%$ (Jönsson, 1977).

Environmental factors, especially temperature and photoperiod during the ripening phase of the seeds, affect the synthesis of the fatty acids (Diepenbrock, 1984). Some researches showed that linolenic acid (C18:3) content was determined mainly by the genotype of the embryo, involving maternal effects and the interaction of two or three loci with some influence from environmental factors (Diepenbrock and Wilson, 1987; Chen and Beversdorf, 1990). Chen and Gertsson (1988) reported more than 80\% oleic acid $(\mathrm{C} 18: 1)$ in $\mathrm{F}_{2}$ seeds which derived from a crossing of breeding line of oilseed (about $60 \%$ oleic acid) and one of resynthesized lines.

Three microspore-derived populations of spring rapeseed (B. napus) were derived from crosses between parental lines with contrasting fatty acid composition differing in amounts of erucic acid (C22:1, o to 42.3\%), oleic acid (C18:1, 20.2 to 69.1\%), linoleic acid (C18:2, 11.1 to 22.8\%) and linolenic acid (C18:3, 2.6 to $11.3 \%$ ) (Chen and Beversdorf, 1990). The same two loci influenced the accumulation of erucic acid and oleic acid, controlling the chain elongation step between oleic acid and erucic acid. Erucic acid was confirmed to be controlled by two major loci, each with two alleles with additive effects. At least two additional loci involving the control of the desaturation step from oleic acid to linoleic acid influenced the amount of oleic acid although to a lesser degree than the genes controlling the chain elongation step of oleic acid to erucic acid. In zero-erucic acid populations, linoleic acid (C18:2) was determined to be under two gene control while the accumulation of linolenic acid (C18:3) was determined to be influenced by three gene loci with additive gene action. 
The inheritance of the low linolenic acid (C18:3) content (derived from mutant lines) in oilseed rape was investigated and gene mapping through RAPD markers was applied on a microspore-derived progeny from a high $\mathrm{x}$ low linolenic acid $\mathrm{F}_{1}$ hybrid. Two linkage groups of 6 makers were determined and it was confirmed that two independent genes were implied in the low linolenic acid (C18:3) content (Jourdren et al. 1996).

An 8-by-8 diallel of different mutants and two crosses between high oleic (HO) mutants and a normal type culitvar with their segregating $F_{2}$ and $B C$ generations were used by Schierholt et al. (2001). The results suggested that the variation in oleic acid (C18:1) can be explained by two mutation events. One mutated locus (HO1) was expressed mainly in the seeds and all mutants were assumed to be allelic at this locus. A second mutated locus ( $\mathrm{HO} 2)$, which increased the oleic acid content not only in the seed but also in leaves and roots, was identified in one mutant line. Both loci showed mainly additive effects: for $\mathrm{HO} 1 \mathrm{a}=8.0 \pm 1.5$ and for $\mathrm{HO} 1+\mathrm{HO} 2 \mathrm{a}=9.25 \pm 1.5$ (in percent oleic acid in the seed oil). Non-significant dominance effects and no epistatic or maternal effects were observed. Moreover, there were environmental effects on seed oleic acid (C18:1), linoleic acid (C18:2) and linolenic acid (C18:3) contents.

Estimation of minimum number of genes affecting seed oleic acid (C18:1) content in the winter oilseed mutant lines 19661 and 19517/7507 were calculated from generation means of the populations Lisabeth $\times 19661$ and Lisabeth $\times 19517 / 7507$. The results suggested that one gene in mutant line 19661 and two genes in mutant line 19517/7507 were controlling seed C18:1 contents. Since 19661, and other mutants 19508, 19517/19566, 19646, and 19684 were allelic in the HO1 locus, it could be concluded that those six mutants showed a monogenic inheritance of the HO traits (Schierholt et al., 2001).

High erucic acid cv. Maplus was crossed to four different doubled haploid high oleic acid winter oilseed rape lines (sister lines; 82-86\%) and single $F_{2}$ seeds were analysed for erucic acid (C22:1) content by gaschromatography (Sasongko, 2003). The $F_{2}$ seeds derived from one of these crosses showed a segregation pattern of $1: 4: 6: 4: 1$, as expected for a digenically inherited trait with additive effects. This segregation pattern was not disturbed by the additional genes for high oleic acid 
(C18:1) segregating in that population and there was no indication that an enhanced oleic acid (C18:1) content leads to improved synthesis of erucic acid (C22:1).

Ecke et al. (1995) mapped the erucic acid (C22:1) genes to linkage groups 6 and 12, and Schierholt et al. (2000) mapped the oleic acid mutation to linkage group 15 using the same molecular marker map. Partial maternal and cytoplasmic effects for oleic acid (C18:1) concentration were observed in the analysis of $F_{1}$ seeds and $F_{1}$ plants from reciprocal crosses of high-erucic acid Ethiopian mustard (B. carinata A. Braun) mutant N2-3591 with the high-erucic acid line C-101, with the standard composition of $C 18$ fatty acids (Velasco et al., 2003). Oleic acid (C18:1) concentration of $F_{2}$ seeds following a 3:1 (standard-intermediate: increased) ratio, suggesting monogenenic inheritance which was confirmed in the $\mathrm{BC}_{1}$ to $\mathrm{N} 2-3591$, which segregation followed a 1:1 (intermediate: increased).

Möllers and Schierholt (2002) reported in seeds from 60 doubled haploid oilseed rape lines evaluated in five environments, a small but significant $D H$ lines $x$ environment interaction for all traits with exception of $\mathrm{C} 16: 0$ and $\mathrm{C} 16: 1$, and a significant environmental effect except for C16:1. Estimated heritabilities were high to very high, and ranged from 0.70 to 0.99 for $\mathrm{C} 16: 2$ and $\mathrm{C} 18: 1$, respectively.

\subsubsection{Glucosinolates}

Inheritance studies indicated that the recessive alleles of at least three genes condition the low glucosinolate characteristic in B. napus. The 'Bronowski' cultivar has been used world-wide in back cross programs to incorporate the low glucosinolate characteristic into adapted cultivars of both $B$. napus and $B$. campestris (Downey and Röbbelen, 1989). The inheritance of glucosinolates is complex being controlled by three partially recessive, unliked genes (Lein, 1972). The presence of several major seed glucosinolates within the pollen grains of Brassica species was first reported in both oilseed rape and Indian mustard. It could be targeted in pollen selection for low glucosinolate varieties (Dungey et al., 1988).

In rapeseed, six QTL for glucosinolate content have been reported by using a segregating doubled haploid population derived from a cross between the old cultivar 'Mansholts' and the canola quality winter cultivar 'Samourai' (Gül, 2002). In this case, three of these QTL have been reported to have major effects while the remaining 3 
showed only minor effects. A similar report was given by Cermakova et al. (1999) using the cross between double low quality winter oilseed rape cultivars 'Tapidor' with the winter variety 'Bienvenu'. A marker assisted backcrossing was carried out using the "TapDH1" (double haploid lines from 'Tapidor') as the recurrent parent and RFLP markers. In this study, three loci influencing the amount of seed glucosinolates have been mapped by QTL analysis to linkage groups $\mathrm{N} 9, \mathrm{~N} 12$ and $\mathrm{N} 19$, controlling together $90 \%$ of the variation of glucosinolates. Other studies using different crosses in $B$. napus also confirmed that at least three important QTL control the glucosinolate content (Howell et al., 2002).

$\mathrm{A} \mathrm{BC}_{2}$ population derived from 'Mansholts' $\mathrm{x}$ 'Samourai' with 'Samourai' as recurrent parent was genetically characterized using markers (Marschalek, 2003). Based on the marker information of $\mathrm{BC}_{2}$ plants, $\mathrm{BC}_{3}$ families segregating for only one of six QTL were selected and grown in field trails and seed glucosinolate content was evaluated. It was reported that the two major QTL on linkage groups 16 and 18 clearly segregated 1:1 into two phenotypic classes. In the $\mathrm{BC}_{3}$ families the QTL effect estimated was the sum of additive and dominance effects, and even epistatic effects were not excluded. But dominance effects were stronger than additive effects. For the QTL on linkage group 18 additive and dominance effects were nearly equal. For the other major QTL the dominance effects were larger than the additive effects. Epistatic effects could also be found in $\mathrm{BC}_{3}$ families segregating for two QTL.

Magrath and Mithen (1993) used reciprocal crosses in Brassica napus to show that the profile of seed aliphatic glucosinolates was identical to that of the maternal plant, and concluded that a de novo synthesis did not occur in the embryo. In contrast, the embryo can sulphonate glucosinolate (Toroser et al., 1995). However no hydroxylation of indole-or alkenyl-glucosinolates occurred in the embryo and no hydroxylated desulphoglucosinolate was found in the pod walls. The heritability for most traits is high, with leaf total aliphatic glucosinolates being the highest with 0.81 . This suggests that genetic factors segregating between the lines control $-80 \%$ of the variation. In contrast, seed total aliphatic glucosinolates had a heritability of only 0.40 . This indicates that genetics contributes $=40 \%$ of the variation while environmental and experimental factors contribute $60 \%$ of the variation. 
The content of seed glucosinolate is controlled by multiple genes and is complexly regulated in the cell (Fenwick et al., 1983; Uzunova et al., 1995). Six loci were identified to determine the aliphatic glucosinolate synthesis and two loci were involved in the hydroxylation of both butenyl and pentenyl glucosinolates in Brassica napus (Magrath et al., 1993). The latter two loci were mapped onto two separate linkage groups (Magrath et al., 1994).

Profile of the seed aliphatic glucosinolates was identical to the maternal parent suggesting the absence of glucosinolate biosynthesis and glucosinolate interconversion within the embryo (Magrath and Mithen, 1993). It was already reported earlier that the total aliphatic glucosinolate content of the seed of Brassica napus and Arabidopsis thaliana were determined by the genotype of the maternal parent rather than the genotype of the zygote (Kondra and Stefansson, 1970; Haughn et al., 1991).

There may be no biosynthesis of glucosinolates within cotyledon tissue and the glucosinolate levels in it are reflecting those of the maternal parent (Glen et al., 1990). However, Rossiter et al. (1990) demonstrated that the enzyme responsible for the hydroxylation of butenyl glucosinolates was active in cotyledons suggesting that some components of glucosinolate biosynthesis occur within this tissue.

Additive effects and most likely positions of four mapped quantitative trait loci (QTLs) controlling seed glucosinolate content in oilseed rape were located at separate linkage groups (2, 9, 16, and 18) (Uzunova et al., 1995). The dominance effects of the mapped QTLs could not be estimated due to the double-haploid nature of the mapping population, but the $F_{1}$ of a cross "Mansholt $x$ Samourai" showed that significant dominance was involved in the expression of that trait. However, the inheritance of the indolyl and aromatic glucosinolates still remains unknown. Marker loci associated with glucosinolate content are expected to be used in marker-assisted selection in order to manipulate the glucosinolate content and to improve the nutritional value of the crops.

The inheritance of three glucosinolate components (goitrin, volatile isothiocyanates and the thiocyanate ion) was studied in cabbage (Brassica oleracea var. capitata). Results indicated that all three components showed a strong heterosis towards lower 
concentrations, the maternal effect in inheritance was observed for goitrin only, lower concentrations of goitrin and volatile isothiocyanates were controlled by four to six genes, and the inheritance of thiocyanate was governed by two to three loci (Chiang et al., 1989).

Result of Lein (1972) showed that biosynthesis of glucosinolates for seed filling takes place partly in the siliqua. The concentration in dry seeds is about five to ten times higher than in vegetative parts and they are storage compounds in seeds.

\subsubsection{Sinapic acid esters}

Sinapic acid esters are antinutritional compounds with amounts of more than $1 \%$ in seeds believed to limit the use of meal for feed. To reduce its amount in oilseed rape, knowledge of inheritance for sinapic esters is required. Field experiments for sinapic acid esters showed high heritabilities for sinapine (0.78), for sinapoylglucose (0.95), and for total content of sinapic acid esters (0.86), respectively (Zum Felde et al., 2003). Moreover, high significant interaction between lines and environments was also reported for all components of sinapic acid esters.

\subsubsection{Tocopherols}

Tocopherol content in oilseed rape is medium to low compared with other oil seed crops. Generally, oilseed rape contains, 64\% $\gamma$-tocopherol, 35\% $\alpha$-tocopherol, and a very low amount $(<1 \%$ ) of $\delta$-tocopherol (Appelqvist, 1972; Goffman and Becker, 2001). Two diallel mating designs with six parents each were used to determine the inheritance of $\alpha, \gamma$, and total tocopherolcontent and $\alpha / \gamma$ tocopherol ratio in oilseed rape by Goffman and Becker (2001). They reported that the $F_{1}$ hybrids showed a significantly higher $\gamma$-tocopherol content in both mating designs. Moreover, general combining ability (GCA) effects were highly significant and much larger than specific combing ability (SCA) effects for all traits studied. Reciprocal effects were not statistically significant. Therefore, tocopherol content and composition are strongly associated with additive gene action in oilseed rape. The ratio of $\alpha$ - to $\gamma$-tocopherol can be used to describe the tocopherol composition in oilseed rape and the ratio varied from 0.31 to 1.40 . Interactions of $F_{1}$ hybrids and GCA effects with the environment were only significant for tocopherol content but not for tocopherol composition. No correlation between $\gamma$-tocopherol and $\alpha$-tocopherol was observed. 


\section{Materials and Methods}

\subsection{Materials}

Two experiments were performed in 2003 at three locations (Göttingen, Einbeck, Teendorf) with two replications. In the first experiment ten different pollen parents of winter oilseed rape were chosen and crossed with two male sterile (MS) lines (Falcon and Express).For each pollen parent a block with seven plots was grown containing three plots of each parent and two plots of each $F_{1}$. In the center, ten single plants of the two female MS parents were transplanted before winter in 2002. With this design, the following generations were produced: parents, $F_{1}, F_{2}$. For details see manuscript I.

For the second experiment six parents were used to produce four crosses. Single $F_{2}$ seeds were analysed and for each cross four bulks were tested: high oil, low oil, high glucosinolates and low glucosinolate, respectively. For details see manuscript III.

\subsection{Methods}

In the first experiment, oil, protein and sinapic acid esters were analysed by nearinfrared reflectance spectroscopy (NIRS), glucosinolate and tocopherol were analysed by high-performance liquid chromatography (HPLC), and fatty acids were analysed by gas liquid chromatography (GLC). In the second experiment NIRS was used for analysing the seed quality of oil, protein, glucosinolates and erucic acid content. The reference methods used in the first experiment are as follows:

\section{Glucosinolate (GSL) analysis by HPLC}

About $200 \mathrm{mg}$ of seeds from the samples were homogenised in a mill and then filled in polypropylene 70/12 tubes. The dry weight was determined and the polypropylene tubes containing the homogenised materials were placed in a water bath heated to $78^{\circ} \mathrm{C}$ for $1 \mathrm{~min}$. For the first glucosinolates extraction, $2 \mathrm{ml} 70 \%$ methanol was added and $200 \mu \mathrm{l}$ of internal standard solution (6 mmol glucotropaeolin / I water) (Thies, 1988) was added. The preparation was mixed twice on a Vortex- mixer during $10 \mathrm{~min}$ extraction. Following extraction, they were centrifuged (Heraeus Varifuge F) for $4 \mathrm{~min}$ at $2400 \mathrm{~g}$. The supernatant was decanted into a polypropylene tube and the pellet once again extracted with $2 \mathrm{ml}$ of $10 \%$ methanol to the sediment and followed again 
as described before. From both GSLs extraction, the supernatants were pooled and $500 \mu \mathrm{l}$ of the extraction sample was pipetted on the top of a small ion-exchanged column (Pasteur pipette) containing $10 \mathrm{mg}$ of Sephadex DEAE-A 25 in the formiate form. The column was washed twice with $1 \mathrm{ml}$ of deionized water. The GSLs were desulfated by adding $100 \mu \mathrm{l}$ sulfatase type H-1 (Sigma S-9626) diluted 1:2.5 water and incubated overnight for $16 \mathrm{~h}$ at $39^{\circ} \mathrm{C}$.

Desulfated glucosinolates were eluted with $500 \mu \mathrm{l} \times 3$ times water, filtered, in $3 \mathrm{ml} P S$ (Polystyrol) tube, then mixed on the VORTEX mixer, and transferred into $1 \mathrm{ml}$ sample vials. From the filtrate, 30-70 $\mu \mathrm{l}$ was injected into the high-performance liquid chromatography (HPLC) analyser equipped with an ultraviolet detector. GSLs were determined by the HPLC gradient method.

The alkenyl/aliphatic glucosinolates determined by HPLC were progoitrin (PRO), sinigrin (SIN), gluconapoleiferin (GNL), gluconapin (GNA), glucobrassicanapin (GBN) and glucoerucin (ERU), the indole GSLs were glucobrassicin (GBC), 4hydroxyglucobrassicin (4OH), neoglucobrassicin (NEO) and 4-methoxyglucobrassicin (4Me), and the aromatic glucosinolate gluconasturtiin (NAS). All GSLs values were converted to $\mu \mathrm{mol} \mathrm{g}^{-1}$ dry weight.

\section{Fatty acid analysis by GLC}

The fatty acids composition of the samples was determined by gas liquid chromatography analyses of fatty acid esters. According to the reference of analysis specifications of the Institute of Agronomy and Plant Breeding, University Göttingen, Germany, the first step was taking about $200 \mathrm{mg}$ homogeneous milled seed from the samples, placed in each $3 \mathrm{ml}-\mathrm{PS}$ (Polystyrol) tube, and added $500 \mu \mathrm{l}$ Na-methylate in methanol $(0.5 \mathrm{~mol} / \mathrm{l})$ ( $9 \mathrm{ml} 5.56 \mathrm{~mol}$ sodium methylate in 1 I methanol-FLUKA 71 748-+ $10 \mathrm{ml}$ isooctane and $100 \mathrm{ml}$ with methanol p.a., $+100 \mu \mathrm{l} 1 \%$ bromocresol green in methanol) and following shaking until the solution was clear and stayed for further $15 \mathrm{~min}$.

Adding $200 \mu \mathrm{l}$ of $5 \% \mathrm{NaHSO}_{4}$ in water and $300 \mu \mathrm{l}$ isooctane, shaking (salt precipitates) them on the VORTEX, and centrifugation at 150xg (1000 rpm). The next step was pipetting ca. $200 \mu \mathrm{l}$ of the upper phase, transfer into each septum vial, and following injection (ca. $2 \mu \mathrm{l}$ ) into the gas chromatography. 
The gas chromatography condition was equipped with a fused silicone capillary column FFAP (Macherey \& Nagel GmbH + Co. Kg, Düren , Germany) 25 m x 0.25 $\mathrm{mm}$ i.d. (0.25 $\mu \mathrm{m}$ film thickness). The column temperature was $210^{\circ} \mathrm{C}$ and the carrier gas was $150 \mathrm{kPa} \mathrm{H}_{2}$ at the split rate of 1:70, and injection/detector temperature was $230^{\circ} \mathrm{C}$. Individual fatty acids, such as palmitic, stearic, oleic, linoleic, linolenic, eicosenoic, erucic acid were determined by GLC and expressed as \% of total fatty acids.

\section{Tocopherol analysis by HPLC}

Oilseed rape samples were homogenised in a mill, and about $50 \mathrm{mg}$ weight was added in polypropylene 70/12 tubes. Oils were obtained by extraction from seed samples by adding $1.5 \mathrm{ml}$ isooctane and then $0.5 \mathrm{ml}$ inner standard $(0.01 \mu \mathrm{g} \beta$ Tocopherol (MERCK 115 496) was diluted with $1 \mu$ isooctane). They were mixed on a VORTEX-mixer and their extraction was allowed over night in darkness. After mixing on the VORTEX again, they were centrifuged. About $1000 \mu$ l supernatant was transferred into $1 \mathrm{ml}$ sample vials. Tocopherol (TOC) was analysed by HPLC with fluorescence detection (Thies, 1997). Tocopherol content is reported as $\mathrm{mg} \mathrm{kg}^{-1}$ air dried seed.

For analysis of variance the software PLABSTAT (Utz, 1997) was used. For genetic analysis a model for diploid seeds proposed by Zhu and Weir (1994) was used. For details see manuscript I. 


\section{Results and Discussion}

\subsection{Which seed quality traits are influenced by pollen genotypes?}

\section{(Manuscripts I and III)}

There are four slightly different approaches used to investigate the influence of pollen parents on seed quality:

1. Correlation between pollen parents and their $F_{1} s$ mean (Figure $1 / 2-1 / 5$ )

2. Analysis of variance of $F_{1}$ seeds with different pollen parents (Table $1 / 4-1 / 8$ )

3. Estimation of genetic effects according to Zhu and Weir (1994) (Table I/9 and 1/10)

4. Response to selection among segregating $F_{2}$ seeds (Table III/5 and III/6)

These results are summarized in Table 2 .

\section{Oil and protein}

For oil content highly significant differences in the analysis of variance for male effects were found and also additive seed effects were significant. The male effects agreed with results from Letchworth and Lambert (1998) on oil content of maize. Moreover, the selection among segregating $F_{2}$ seeds showed significant response. Highly significant effects of seed dominant effects and response to selection among segregating $F_{2}$ seeds were found for protein content.

\section{Fatty acids}

All fatty acids except linolenic acid showed significant correlations between pollen parents and $F_{1}$. Direct seed effects were observed for C18:1, C18:2, C20:1 and C22:1 contents.

\section{Glucosinolates}

Based on the results of correlation between pollen parents and their $F_{1} s$ mean, a significant influence of pollen parents on the next generation was shown for sinigrin $\left(r=0.61^{+}\right)$, gluconapoleiferin $\left(r=0.85^{* *}\right)$, 4-hydroxyglucobrassicin $\left(r=0.76^{*}\right)$, indole glucosinolates $\left(r=0.74^{*}\right)$, indole/aliphatic glucosinolates $\left(r=0.74^{*}\right)$. The total glucosinolate (GSL) content is mainly determined by aliphatic GSL and was not significantly influence by the pollen genotype. The result for the analysis of variance showed significant effects of pollen male parents for indole glucosinolate and the 
ratio indole/aliphatic glucosinolate. Both indole and aliphatic glucosinolate contents showed direct seed effects in estimation of genetic effects. Significant response to selection was found for total glucosinolate content.

\section{$\underline{\text { Sinapic acid esters }}$}

Among sinapic acid esters, sinapoylglucose $\left(r=0.63^{*}\right)$, rest of unknown sinapic acid esters $\left(r=0.82^{* *}\right)$ and total sinapic acid esters $\left(r=0.62^{+}\right)$showed significant correlations between pollen parents and their $F_{1} s$ mean. Direct seed effects were observed for sinapoylglucose and the rest of unknown sinapic acid esters.

\section{Tocopherols}

For tocopherols, only four parents and their $F_{1} s$ were analysed. The pollen parents showed significant effects for $\gamma$-tocopherol and $\alpha / \gamma$-tocopherol .

In conclusion, not only the fatty acids, but also oil, protein, sinigrin, gluconapoleiferin, indole glucosinolate, 4-hydroxyglucobrassicin, indole/aliphatic glucosinolate, sinapoylglucose, sinapine, rest of unknown sinapic acid ester, total sinapic acid ester, $\alpha / \gamma$-tocopherol, and $\gamma$-tocopherol contents were influenced by the pollen parent genotype. 
Table 2. Results of different approaches for influence of pollen genotype effects.

\begin{tabular}{|c|c|c|c|c|c|}
\hline \multirow{2}{*}{ Seed quality traits } & \multirow{2}{*}{$\begin{array}{l}\text { Correlation } \\
(\mathrm{r}) \text { between } \\
\text { pollen } \\
\text { parents } \\
\text { and } \mathrm{F}_{1}\end{array}$} & \multirow{2}{*}{$\begin{array}{l}\text { Male } \\
\text { effects in } \\
\text { analysis of } \\
\text { variance }\end{array}$} & \multicolumn{2}{|c|}{$\begin{array}{c}\text { Genetic effects for } \\
\text { seed }\end{array}$} & \multirow{2}{*}{$\begin{array}{l}\text { Significance } \\
\text { of selection } \\
\text { of single } \\
\text { seeds }\end{array}$} \\
\hline & & & $\begin{array}{l}\text { Direct } \\
\text { seed } \\
\text { effects }\end{array}$ & $\begin{array}{l}\text { Dominant } \\
\text { seed } \\
\text { effects }\end{array}$ & \\
\hline Oil & 0.35 & $* *$ & $10.25^{\star *}$ & ns & + \\
\hline Protein & 0.43 & ns & ns & $0.68^{* *}$ & ** \\
\hline \multicolumn{6}{|l|}{ Fatty acids } \\
\hline$-C 18: 1$ & $0.94^{* *}$ & ** & $201.30^{* *}$ & ns & - \\
\hline$-C 18: 2$ & $0.80^{* *}$ & ** & $6.87^{* *}$ & ns & - \\
\hline$-C 18: 3$ & 0.46 & * & ns & ns & - \\
\hline$-C 20: 1$ & $0.95^{\star *}$ & ** & $32.46^{* *}$ & $0.71^{* *}$ & - \\
\hline$-C 22: 1$ & $0.97^{* *}$ & ** & $46.48^{* *}$ & $0.85^{\star *}$ & - \\
\hline \multicolumn{6}{|l|}{ Glucosinolates (GSLs) } \\
\hline Indole glucosinolates & $0.74^{*}$ & ** & $1.08^{* *}$ & ns & - \\
\hline -4-hydroxyglucobrassicin & $0.76^{* *}$ & - & - & - & - \\
\hline Aliphatic glucosinolates & 0.21 & - & $16.81^{\star *}$ & ns & - \\
\hline -Sinigrin & $0.61^{+}$ & - & - & - & - \\
\hline -Gluconapoleiferin & $0.85^{* *}$ & ns & - & - & - \\
\hline Total & 0.18 & ns & $11.91^{* *}$ & ns & + \\
\hline \multicolumn{6}{|l|}{$\begin{array}{l}\text { Sinapic acid esters } \\
\text { (SAEs) }\end{array}$} \\
\hline -Sinapoylglucose & $0.63^{*}$ & * & $0.25^{* *}$ & $0.04^{* *}$ & - \\
\hline -Sinapine & 0.51 & ns & ns & $0.14^{* *}$ & - \\
\hline -Rest & $0.82^{* *}$ & ns & $0.06^{* *}$ & $0.01^{* *}$ & - \\
\hline Total & $0.62^{*}$ & ns & ns & $26.09^{* *}$ & - \\
\hline \multicolumn{6}{|l|}{ Tocopherols } \\
\hline - $\alpha$-tocopherol & - & ns & - & - & - \\
\hline$-\gamma$-tocopherol & - & + & - & - & - \\
\hline$-\alpha / \gamma$-tocopherol & - & * & - & - & - \\
\hline Total & - & ns & - & - & - \\
\hline
\end{tabular}

$+,{ }^{*},{ }^{*}=$ significantly difference at $P=0.10, P=0.05$ and $P=0.01$, respectively; ns $=$ not significant and $-=$ not analysed. 
The content in all three seed quality traits showed significant differences after selection. Therefore, it can be suggested that it is possible to select for oil, protein and glucosinolate content among segregating $F_{2}$ seeds by near-infrared reflectance spectroscopy (NIRS). 


\section{Summary}

\section{Pollen genotype effects on seed quality and selection of single seeds by near- infrared reflectance spectroscopy (NIRS) in winter oilseed rape}

Oilseed rape is one of the most important oilseed crops of the world. Because of the success in quality breeding, the growing area of oilseed rape is gradually increasing. Although the seed quality is a very important breeding objective, the inheritance of the seed quality is not yet completely understood. It is often assumed, that most seed quality traits like oil, protein and glucosinolate (GSL) content are only determined by the maternal plant on which the seeds is grown and not influenced by the genotype of the pollinator. Therefore, the main objective of this study is to determine the effects of the pollen genotype on the important seed quality traits oil, protein, glucosinolate, tocopherol and sinapic acid content.

Two separate experiments were conducted to meet this objective. In the first experiment ten pollen parents and two male sterile females (Falcon and Express) were used. For each pollen parent blocks with seven plots were grown containing three plots of the parent between two plots of each $F_{1}$. Ten single plants of the two male sterile parents were transplanted into the center of the pollinator plots by hand before winter. The experiment was performed with two replications in a randomized complete block design at three locations (Göttingen, Einbeck, and Teendorf) in the season 2002/2003. With this experimental design, the seeds of the following generations were produced: pollen parents (harvesting plants from the center of the pollen parent plots), $F_{1} s$ (harvesting the transplanted male sterile plants), and $F_{2} S$ (harvesting plants in the center of the $F_{1}$ plots). The seed quality traits oil, protein and sinapic acid ester content were analysed by near-infrared reflectance spectroscopy (NIRS), glucosinolate and tocopherol contents were analysed by high performance liquid spectroscopy (HPLC), and the fatty acids were analysed by gas liquid chromatography (GLC).

In the second experiment single $F_{2}$ seeds from four crosses were analysed by NIRS for protein and glucosinolate content. In each cross four bulks were selected: high and low in protein and in glucosinolate, respectively. In the season 2002/2003 the four bulks from each cross were grown in a randomized complete block design with two replications in three locations (Göttingen, Einbeck, Teendorf). Six parental lines 
were also included in the experiment. The seed quality traits oil, protein and glucosinolate content were analysed by near-infrared reflectance spectroscopy (NIRS). Different approaches were used to analyse the results of both experiments: correlation between pollen parents and $F_{1} S$, analysis of variance, analysis of genetic effects, and single seed selection among segregating $F_{2}$ seeds. The data of the first experiment was analysed by an analysis of variance and by the method of Zhu and Weir (1994).

In the first experiment, the results have revealed that highly significant correlations between pollen parents and $F_{1} s$ were observed for indole GSL, sinapoylglucose and total sinapic acid ester. In the analysis of variance, significant effects for pollen genotype were observed for oil, indole GSL, indole/aliphatic GSL, fatty acids, sinapoylglucose, $\gamma$-tocopherol and $\alpha / \gamma$-tocopherol. Aliphatic GSL and total GSL contents were influenced by seed direct effects which express additive gene action in embryo, and sinapine and sinapic acid esters were influenced by the seed dominant effects which express dominant gene action in embryo, respectively. In the second experiment the response to selection of $F_{2}$ single seeds from individual plants was investigated. First reliable NIRS calibration equations for the single seeds were developed with a wide-range of oil, protein, and glucosinolate content. High correlations of $R^{2}=0.98, R^{2}=0.99$ and $R^{2}=0.97$ were found between the reference methods and the NIRS predictions for the contents of oil, protein and glucosinolate, respectively. When comparing the seed quality between selfed and open pollinated plants of the parents, higher oil content $(+2.2 \%)$, lower protein content $(-2 \%)$ and lower glucosinolate content $(-3.9 \mu \mathrm{mol} / \mathrm{g})$ was observed in the open pollinated plants. The selection of single seeds resulted in significant responses to selection for oil, protein and glucosinolate content.

Based on these results, it can be concluded that not only the fatty acid contents were influenced by the pollen genotype, but also contents of oil, sinigrin, gluconapoleiferin, 4-hydroxyglucobrassicin, indole glucosinolate, indole/aliphatic glucosinolate, sinapoylglucose, total sinapic acid esters, $\gamma$-tocopherol and $\alpha / \gamma$-tocopherol. In some cases pollen influences were also observed for aliphatic glucosinolate, total glucosinolate, protein and sinapine contents. 
Therefore the pollen genotype has to be considered as disturbing factor when harvesting open pollinated plants and selection of single seeds in the segregating $F_{2}$ generation is possible. 


\section{Zusammenfassung}

\section{Einfluss des Pollen-Genotyps auf die wertbestimmenden Inhaltsstoffe und} Selektion von Einzelsamen mit Hilfe der Nah-Infrarot-ReflektionsSpektroskopie (NIRS) bei Winterraps

Raps ist eine der wichtigsten Ölpflanzen auf der Welt. Die grosse Anbaubedeutung von Raps beruht ganz wesentlich auf züchterischen Veränderungen der Inhaltsstoffe des Samens. Trotz der grossen praktischen Bedeutung der wertbestimmenden Inhaltsstoffe des Samens ist deren Vererbung noch nicht vollständig bekannt. Bisher wird oft vereinfachend angenommen, dass Samenmerkmale wie z.B. der Ölgehalt nur von der Mutterpflanze und nicht vom Pollen-Genotyp abhängen. Diese Annahme ist jedoch nicht durch experimentelle Befunde gestützt. Grundsätzlich können die Inhaltsstoffe des Samens sowohl von der mütterlichen Pflanze, auf der die Samen geerntet werden, als auch von dem väterlichen Elter, also der Pollenquelle, beeinflusst werden. Gesamtziel des Projektes ist es daher, für wichtige wertbestimmende Inhaltsstoffe des Rapssamens (Gehalte an Öl, Protein, Glucosinolaten, Tocopherole und Sinapin) einen möglichen Einfluss des PollenGenotyps systematisch zu untersuchen und zu quantifizieren.

Zur Klärung dieser Frage wurden zwei Experimente durchgeführt. Für das erste Experiment wurden 10 Pollen-Eltern und 2 pollensterile Testerlinien (Falcon und Express) verwendet. Für jeden der Bestäuber wurde in jeder Wiederholung ein Block von 7 Parzellen angelegt (3 Parzellen des Bestäubers und je 2 Parzellen für die beiden $\mathrm{F}_{1}$ en mit den beiden Testern). In die Mitte der drei Bestäuberparzellen wurden Einzelpflanzen der beiden pollensterilen Tester umgepflanzt. Der Versuch wurde an drei Orten (Göttingen, Einbeck, Teendorf) mit zwei Wiederholungen 2002/2003 angelegt. Auf diese Weise konnte im selben Versuch Saatgut von drei Generationen geerntet wurden: Eltern (Einzelpflanzen im Kern der Bestäuberparzellen), $F_{1}$ (auf den umgepflanzten pollensterilen Pflanzen) und $F_{2}$ (Einzelpflanzen im Kern der $F_{1^{-}}$ Parzellen). Inhaltsstoffe der Rapssamen (Öl, Protein und Sinapinsäureester) wurden mit Hilfe der Nah-Infrarot-Reflektions-Spektroskopie (NIRS) analysiert. Die Fettsäureanalyse wurde mit Gaschromatographie (GC) vorgenommen. Zur Analyse des Glucosinolatgehaltes wurde das Verfahren der Hochdruck-FlüssigkeitsChromatographie (HPLC) verwendet. 
In dem zweiten Experiment wurde an Einzelsamen innerhalb der spaltenden $\mathrm{F}_{2^{-}}$ Generation von vier Kreuzungen mit Hilfe von NIRS auf Protein- und Glucosinolatgehalt selektiert. Bei jeder dieser vier Kreuzungen wurden vier Ramsche (Hoch/Niedrig Proteingehalt und Hoch/Niedrig Glucosinolatgehalt) gebildet. Im Jahr 2002/2003 wurden die vier Ramsche je Kreuzung mit zwei Wiederholungen an drei Standorten (Göttingen, Einbeck, Teendorf) angebaut. Die sechs Elternlinien wurden ebenfalls geprüft.

Es werde eine varianzanalytische Verrechnung und eine genetische Analyse nach Zhu und Weir (1994) durchgeführt. Mit verschiedenen Methoden (Grad des Korrelation zwischen Pollen-Eltern und $\mathrm{F}_{1}$-Generation, Varianzanalyse, genetische Analyse und Selektion von Einzelsamen innerhalb der spaltenden $\mathrm{F}_{2}$-Generation) wurde der Einfluss des Pollen-Genotyps untersucht.

Im ersten Experiment zeigten sich signifikante Korrelationen zwischen den PollenEltern und den $\mathrm{F}_{1}$-Generationen im Gehalt an Indol-Glucosinolaten, Sinapoylglucose und Total-Sinapinsäureester. Bei der statistischen Analyse wurden signifikante Polleneinflüsse bei den Merkmalen Öl, Indol-Glucosinolate, Indol/AliphatischeGlucosinolate, Fettsäuren (außer Linolensäure), Sinapoylglucose, $\gamma$-Tocopherol und $\alpha / \gamma$-Tocopherol festgestellt. Für aliphatische Glucosinolate und Total-Glucosinolate zeigten sich Additiveffekte der Gene des Embryos, und für Sinapin, und TotalSinapinsäureester zeigten sich Dominanzeffekte der Gene des Embryos.

Im zweiten Experiment wurde der Erfolg einer Selektion von Einzelsamen innerhalb der spaltenden $\mathrm{F}_{2}$-Generation untersucht. Zunächst wurden NIRS Kalibrierungen für den Öl-, Protein- und Glucosinolatgehalt in Einzelsamen entwickelt. Die Kalibrierungsstatistiken zeigten eine hohe Korrelationen für Ölgehalt $\left(R^{2}=0.98\right)$, Proteingehalt $\left(R^{2}=0.99\right)$ und Glucosinolate $\left(R^{2}=0.97\right)$ zwischen den Referenzmethoden und den NIRS-Werten. Die Variation zwischen den auf hohe beziehungsweise auf niedrige Gehalte an Öl, Protein und Glucosinolate selektierten Populationen war signifikant. Der Ölgehalt der Samen von offen abgeblühten Pflanzen war höher $(+2.2 \%)$ als der von Samen aus Selbstbefruchtung der ElternLinien. Im allgemeinen waren der Proteingehalt (-2\%) und der Glucosinolatgehalt $(-3.9 \mu \mathrm{mol} / \mathrm{g})$ niedriger bei offen abgeblühten Pflanzen als bei Samen aus Selbstbefruchtung. 
Aufgrund der Ergebnisse der Untersuchungen ergab sich ein Einfluss des PollenGenotyps nicht nur auf den Fettsäuregehalt, sondern auch auf die Gehalte an Öl, Sinigrin, Gluconapoleiferin, 4-Hydroxyglucobrassicin, Indol-Glucosinolate, Aliphatische-Glucosinolate, Indol/Aliphatische-Glucosinolate, Total-Glucosinolate, Sinapoylglucose, Sinapinsäureester, $\gamma$-Tocopherol und $\alpha / \gamma$-Tocopherol. Additiveffekte der Kerngene des Embryos zeigten sich für aliphatische Glucosinolate und TotalGlucosinolate. Für den Protein und Sinapingehalt zeigten sich Dominanzeffekte der Gene des Embryos.

Daher muß damit gerechnet werden, daß der Pollen-Genotyp die Inhaltsstoffe der Samen von offen abgeblühten Pflanzen beeinflussen kann. Anderseits ist es möglich, bereits an Einzelsamen von $\mathrm{F}_{2}$ Pflanzen erfolgreich zu selektieren. 


\section{References}

Appelqvist, L. A. 1972. Other lipids. In Rapeseed, Cultivation, Composition, Processing and Utilization, Elsevier, Amsterdam, pp.145-147.

Bak, S., and R. Feyereisen. 2001. The involvement of two cytochrome P450 enzymes, CYP83B1 and CYP83A1, in auxin homeostasis and glucosinolate biosynthesis. Plant Physiology 127:108-118.

Bak, S., F.E. Tax, K.A. Feldmann, D.W. Galbraith, and R. Feyereisen. 2001. CYP83B1, a cytochrome P450 at the metabolic branch point in auxin and indole glucosinolate biosynthesis in Arabidopsis. Plant Cell 13:101-111.

Becker H.C., H. Löptien, and G. Röbbelen. 1999. Breeding: An overview. In: GòmezCampo, C. (eds): Biology of Brassica Coenospecies. Elsevier, Amsterdam, pp.413-460.

Bjerg, B., and H. Sørensen. 1987. Isolation of intact glucosinolates by column chromatography and determination of their purity. In: Wathelet J.P. (eds): World Crops: Production, Utilization, Description; Glucosinolates in Rapeseeds: Analytical Aspects. Martinus Nijhoff, Boston, pp.59-75.

Bones, A.M., S. Visvalingam, and O.P. Thangstad. 1994. Sulphate can induce differential expression of thioglucoside glucohydrolase (myrosinases). Planta 193:558-566.

Bones, A.M., and J.T. Rossiter. 1996. The myrosinase-glucosinolate system, its organisation and biochemistry. Plant Physiology 97:184-208.

Brown, P.D., and M.J. Morra. 1997. Control of soil-borne plant pests using glucosinolate-containing plants. Advances in Agronomy 61:167-231.

Cermakova, L., A. Sharpe, M. Trick, M. Bechyne and D. Lydiate. 1999. Genetic analysis of quantitative traits in brassica napus using substitution lines [CDROM]. Proceedings of the $10^{\text {th }}$ International Rapeseed Congress, Canberra, Australia. 
Chen, B.Y., and B. Gertsson. 1988. Genotypes for high oleicacid content (about $80 \%$ ) in the oil of rapeseed (Brassica napus L.). EUCARPIA Cruciferae News Letter 13:46-47.

Chen, J.L., and W.D. Beversdorf. 1990. Fatty acid inheritance in microspore-derived populations of spring rapeseed (Brassica napus L.). Theoretical and Applied Genetics 80:465-469.

Chiang, M.S., C. Chong, G. Chevrier, and R. Crete. 1989. Glucosinolates in clubrootresistant and-susceptible selections of Broccoli. Horticulture Science 24:665666.

Chrispeels, M.J., and E. M. Herman. 2000. Endoplasmic reticulum-derived compartments function in storage and as mediators of vacuolar remodeling via a new type of organelle, precursor protease vesicles. Plant Physiology 123:1227-1234.

Chubb, L.G. 1982. Anti-nutritive factors in animal foodstuffs. In: Haresign, W. (eds): Recent Advances in Animal Nutrition. Butterworths, London, pp.21-37.

Da Silva, J., B. Pierrat , J. Mary, and W. Lesslauer. 1997. Blockade of p38 mitogenactivated protein kinase pathway inhibits inducible nitric-oxide synthase expression in mouse astrocytes. Journal of Biological Chemistry 272: 2837338380 .

De Quiros, H.C., R. Magrath, D. McCallum, J. Kroymann, D. Schnabelrauch, T, Mitchell-Olds, and R. Mithen. 2000. $\leftleftarrows-K e t o$ acid elongation and glucosinolate biosynthesis in Arabidopsis thaliana. Theoretical and Applied Genetics 101:429-437.

Demurin, Y., D. Skoric, and D. Karlovic. 1996. Genetic variability of tocopherol composition in sunflower seeds as a basis of breeding for improved oil quality. Plant Breeding 115:33-36.

Diepenbrock, W. 1984. Einfluß der Temperatur auf die Fettsäurezusammensetzung von Triglyceriden und Galactolipiden aus Rapssamen (Brassica napus L.). Zeitschfrift für Acker und Pflanzenbau 153:208-215. 
Diepenbrock, W., and R.F. Wilson. 1987. Genetic regulation of linolenic acid concentration in rapeseed. Crop Science 27:75-77.

Downey, R.K., and B.M. Craig. 1964. Genetic control of fatty acid biosynthesis in rapeseed (Brassica napus L.). Journal of American Oil Chemistry Society 41:475-478.

Downey, R.K., and G. Röbbelen. 1989. Brassica Species. In: Downey, R.K., G. Röbbelen, and A. Ashri (eds): Oil Crops of the World, McGraw-Hill, New York. pp.339-362.

Dungey, S.G., J.P. Sang, N.E. Rothnie, M.V. Palmer, D.G. Burke, R.B. Knox, E.G. Williams, E.P. Hiliard, and P.A. Salisbury. 1988. Glucosinolates in the pollen of rapedeed and Indian mustard. Phytochemistry 27:815-817.

Dutta, A., and S.K. Dutta. 2003. Vitamin E and its role in the prevention of atherosclerosis and carcinogenesis. Journal of the American College Nutrition 22:258-268.

Ecke, W., M. Uzunova, and K. Weißleder. 1995. Mapping the genome of rapeseed (Brassica napus L.). II. Localisation of genes controlling erucic acid synthesis and seed oil content. Theoretical and Applied Genetics 91:972-977.

Engqvist, G.M., and H.C. Becker. 1991. Relative importance of parameters for selecting between oilseed rape crosses. Hereditas 115:25-30.

Fenwick, G.R., R.K. Heaney, and W.J. Mullin. 1983. Glucosinolates and their breakdown products in food and food plants. Critical Review in Food Science and Nutrition 18:123-201.

Frandsen, G.I., J. Mundy, and J.T.C. Tzen. 2001. Oil bodies and their associated proteins, oleosin and caleosin. Plant Physiology 112:301-307.

Glen, D.M., H. Jones and J.K. Fieldsend. 1990. Damage to oilseed rape seedlings by the field slug Deroceras reticulatum in relation to glucosinolate concentration. Annuals of Applied Biology 117:197-207. 
Goffman, F. D., and H.C. Becker. 2001. Diallel analysis for tocopherol contents in seeds of rapeseed. Crop Science 41:1072-1079.

Grami, B., and B.R. Stefansson. 1977a. Paternal and maternal effects on protein and oil content in summer rape. Canadian Journal of Plant Science 57:945-949.

Grami, B., and B.R. Stefansson. 1977b. Gene action for protein and oil content in summer rape. Canadian Journal of Plant Science 57:625-631.

Grami, B., R.J. Baker, and B.R. Stefansson. 1977. Genetics of protein and oil content in summer rape: Heritability, number of effective factors, and correlations. Canadian Journal of Plant Science 57:939-943.

Graser, G., B. Schneider, N.J. Oldham, and J. Gershenzon. 2000. The methionine chain elongation pathway in the biosynthesis of glucosinolates in Eruca sativa (Brassicaceae). Archives of Biochemistry and Biophysics 378:411-419

Gül, M.K. 2002. QTL-Kartierung und Analyse von QTL x Stickstoff Interaktion beim Winterraps (Brassica napus L.) Doctoral Dissertation, Georg-AugustUniversity Göttingen.

Halkier B.A., and L. Du. 1997. The biosynthesis of glucosinolates. Trends in Plant Science 2:425-431.

Hansen, C.H., U. Wittstock, C.E. Olsen, A.J. Hick, J.A. Pickett, and B.A. Halkier. 2001. Cytochrome P450 CYP79F1 from Arabidopsis catalyzes the conversion of dihomomethionine and trihomomethionine to the corresponding aldoximes in the biosynthesis of aliphatic glucosinolates. Journal of Biological Chemistry 276:11078-11085.

Harada, J. 1994. Seed maturation and control of dormancy. In: Larkins, B.A., (eds): Cellular and Molecular Biology of Plant Seed Development. Kluwer Academic Publishers, Dordrecht, pp.545-592.

Harvey, B.L., and R.K. Downey. 1964. The inheritance of erucic acid content in rapeseed (Brassica napus). Canadian Journal of Plant Science 44:104-111. 
Haughn G.W., L. Davin, M. Giblin, and E.W. Underhill. 1991. Biochemical genetics of plant secondary metabolites in Arabidopsis thaliana: the glucosinolates. Plant Physiology 97:217-226.

Herman, E.M. 1995. Cell and molecular biology of seed oil bodies. In: Kigel, J., G. Gallili, and M. Dekker (eds): Seed Development and Germination. Marcel Dekker, New York, pp.195-214.

Howell, E., C.G.C. Barker, G.H. Jones, M.J. Kearsey, and G.J. King. 2002. Integration of the cytogenetic and genetic linkage maps of Brassica oleracea. Genetics 161:1225-1234.

Huang, A.H.C. 1992. Oil bodies and oleosins in seeds. Annual Review in Plant Physiology and Plant Molecular Biology 43:177-200.

Huang, H.Y., A.J. Alberg, E.P. Norkus, S.C. Hoffman, G.W. Comstock, and K.J. Helzlsouer. 2003. Prospective study of antioxidant micronutrients in the blood and the risk of developing prostate cancer. American Journal of Epidemiology 157:335-344.

Johnson, I.T. 2002. Glucosinolates: Bioavailability and importance to health. International Journal of Vitamin and Nutrient Research 72:26-31.

Jönsson, R. 1977. Erucic-acid heredity in rapeseed (Brassica napus L. and Brassica campestris L.). Hereditas 86:159-170.

Jourdren, C., P. Barret, R. Horvais, D. Brunel.,R. Delourme, and M. Renard. 1996. Identification specific molecular marker of the genes controlling linolenic acid content in rapeseed. Theoretical and Applied Genetics 93:512-518.

Kjaer, A. 1976. Glucosinolates in the Cruciferae. In: Vaughan, J.G., A.J. Macleod, and B.M.G. Jones (eds): The Biology and Chemistry of the Cruciferae. Academic Press, London, pp.207-219. 
Kimber, D.S., and D.I. McGregor. 1995. The Species and Their Origin, Cultivation and World Production. In: Kimber, D.S., and D.I. McGregor (eds): Brassica Oilseed; Production and Utilization. Centre for Agriculture and Biosciences International, University Press, Cambridge, pp.1-7.

Kliebenstein, D.J., J. Kroymann, P. Brawn, A. Figuth, D. Pedersen, J. Gershenzon, and T. Mitchell-Olds. 2001. Genetic contorol of natural variation in Arabidopsis glucosinolate accumulation. Plant Physiology 126:811-825.

Kondra, Z.P., and B.R. Stefansson. 1970. Inheritance of the major glucosinolates of rapeseed (B. napus) meal. Canandian Journal of Plant Science 50:643-647.

Kroymann, J., S. Textor, J.G. Tokuhisa, K.L. Falk, S. Bartram, J. Gershenzon, and T. Mitchell-Olds. 2001. A gene controlling variation in Arabidopsis glucosinolate composition is part of the methionine chain elongation pathway. Plant Physiology 127:1077-1088.

Lehfeldt, C., A.M. Shirley, K. Meyer, M.O. Ruegger, J.C. Cusumano, P.V. Viitanen, D. Strack and C. Chapple. 2000. Cloning of the SNG1 gene of Arabidopsis reveals a role for a serine carboxypeptidase-like protein as an acyltransferase in secondary metabolism. Plant Cell 12:1295-1306.

Lein, K. 1972. Genetische und physiologische Untersuchungen zur Bildung von Glucosinolaten in Rapssamen. I: Zur Vererbung der Glucosinolatarmut. Zeitschrift für Pflanzenzüchtung 67:243-256.

Letchworth, M.B., and R.J. Lambert. 1998. Pollen parent effects on oil, protein, and starch concentration in maize kernels. Crop Science 38:363-367.

Linsinger, T., N. Kristiansen, N. Beloufa, H. Schimmel., and J. Pauwels. 2001. The certification of the total glucosinolate and sulphur contents of three rapeseed (colza) materials: BCR information reference material. Report 19764 EN (European Commissin), Geel, Belgium, 33 p.

Lühs, W., and W. Friedt. 1995. Breeding high-erucic acid rapeseed by means of Brassica napus resynthesis. Proceedings of the $9^{\text {th }}$ International Rapeseed Congress (GCIRC), Cambridge, United Kingdom, pp.449-451. 
MacLeod, A.J., and J.T. Rossiter. 1985. The occurrence of activity of epithiospecifier protein in some Cruciferae seeds. Phytochemistry 24:18951898.

MacLeod, A.J., and J.T. Rossiter. 1987. Degradation of 2-hydroxybut-3enylglucosinolate (progoitrin). Phytochemistry 26:669-673.

Magrath, R., and R. Mithen. 1993. Maternal effects on the expression of individual aliphatic glucosinolates in seeds and seedlings of Brassica napus. Plant Breeding 111:249-252.

Magrath, R., C. Herron, A. Giamoustaris, and R, Mithen. 1993. The inheritance of aliphatic glucosinolates in Brassica napus. Plant Breeding 111:55-72.

Magrath, R., F. Bano, M. Morgner, I. Parkin, A. Sharpe, C. Lister, C. Dean, J. Turner, D. Lydiate, and R. Mithen.1994. Genetics of aliphatic glucosinolates. I. Side chain elongation in Brassica napus and Arabidopsis thaliana. Heredity 72:290-299.

Mansfield, S.G., and L.G. Briarty. 1991. Early embryogenesis in Arabidopsis thaliana. II. The developing embryo. Canadian Journal of Botany 69:461-476.

Marillia, E-F., J.M. MacPherson, E.W.T. Tsang, K.V. Audenhove, W.A. Keller, and J.W.D. GrootWassink. 2001. Molecular cloning of a Brassica napus thiohydroximate S-glucosyltransferase and its expression in Escherichia coli. Physiologia Plantarum 113:176-184.

Marschalek, R. 2003. Marker Assisted Selection for the development of intervarietal substitution for the develoment of QTL effects for glucosinolate content. Doctoral Dissertation, Georg-August-University Göttingen.

Martini, N., T. Möhlmann, J. Schell, and H.E. Neuhaus. 1999. Modulation of starch accumulation and energy supply may alter oil content in rape seeds [CDROM]. Proceedings of the $10^{\text {th }}$ International Rapeseed Congress, Canberra, Australia. 
Marwede, V., C. Möllers, J. Olenjniczak, and H.C. Becker. 2003. Genetic variation, genotype $x$ environment interactions and heritabilities of tocopherol content in winter oilseed rape (Brassica napus L.). Proceedings of the $11^{\text {th }}$ International Rapeseed Congress, Copenhagen, Denmark, pp.212-214.

Mikkelsen, M.D., C.H. Hansen, U. Wittstock, and B.A. Halkier. 2000. Cytochrome P450 CYP79B2 from Arabidopsis catalyzes the conversion of tryptophan to indole-3-acetaldoxime, a precursor of indole glucosinolates and indole-3acetic acid. Journal of Biological Chemistry 275:33712-33717.

Mikkelsen, M.D., B.L. Peterson, E. Glawischnig, A.B. Jensen, E. Andreason, and B.A. Halkier. 2003. Modulation of CYP79 genes and glucosinolate profiles in Arabidopsis by defense signaling pathways. Plant Physiology 131:298-308.

Möllers, C., and A. Schierholt. 2002. Genetic variation of palmitate and oil content in a winter oilseed rape doubled haploid population segregating for oleate content. Crop Science 42:379-384.

Murphy, D.J. 1993. Structure, function and biogenesis of storage lipid bodies and oleosins in plants. Progress in Lipid Research 32:247-280.

Murphy, D.J., and J. Vance. 1999. Mechanisms of lipid-body formation. Trends in Biochemical Science 24:109-115.

Ohlrogge, J., and J. Browse. 1995. Lipids Biosynthesis. American Society of Plant Physiologists. Plant Cell 7:957-970.

Ohlrogge, J.B., D.N. Kuhn, and P.K. Stumpf. 1979. Subcellular localization of acyl carrier protein in leaf protoplasts of Spinacia oleracea. Proceedings of the National Academy of Sciences of the United States of America, 78:11941198.

Okuley, J., J. Lightner, K. Feldmann, N. Yadav, E. Lark, and J. Browse. 1994. Arabidopsis FAD2 gene encodes the enzyme that is essential for polyunsaturated lipid synthesis. Plant Cell 6:147-158. 
Petersen, B.L., S. Chen, C.H. Hansen, C.E. Olsen, and B.A. Halkier. 2002. Composition and content of glucosinolates in developing Arabidopsis thaliana. Planta 214:562-571.

Petroski, R.J., and W.F. Kwolek. 1985. Interactions of a fungal thioglucoside glucohydrolase and cruciferous plant epithiospecifier protein to form 1cyanoepithio-alkanes; implications of an allosteric mechanism. Phytochemistry 24:213-216.

Perarson, A., E.J. Butler, and G. R. Fenwich. 1989. Rapeseed meal and egg taint: the role of sinapine. Journal of the Science of Food and Agriculture 31:898904.

Rakow, R., and J.P. Raney. 2003. Present status and future perspectives of breeding for seed quality in Brassica oilseed crops. Proceedings of the $11^{\text {th }}$ International Rapeseed Congress, Copenhangen, Denmark, pp.181-185.

Reed, D.W., L. Davin, J.C. Jain, V. Deluca, L. Nelson, and E.W. Underhill. 1993. Purification and properties of udp-glucose-thiohydroximate glucosyltransferase from brassica-napus 1 seedlings. Archives of Biochemistry and Biophysics 305:526-532.

Röbbelen, G., and W. Thies. 1980. Biosynthesis of seed oil and breeding for improved meal quality. In: Tsunoda, S., K. Hinata, and C. Gòmez-Campo (eds): Brassica Crops and Wild Allies: Biology and Breeding. Japan Scientific Societies Press, Tokyo, pp.285-299.

Rosa, E.A.S. 1999. Chemical composition. In: Gòmez-Campo, C. (eds): Biology of Brassica Coenospcies, Elsevier, Amsterdam, pp.315-357.

Rossiter, J. T., D.C. James, and N. Atkins, 1990 Biosynthesis of 2-hydroxy-3butenylglucosinolate and 3-butenylglucosinolate in Brassica napus. Phytochemistry 29:2509-2512.

Sasongko, N.D. 2003. Increase of erucic acid content in oilseed rape (Brassica napus L.) through the combination with genes for oleic acid. Doctoral Dissertation, Georg-August-University Göttingen. 
Savidge, B., J.D. Weiss, Y.H. Wong, M.W. Lassner, T.A. Mitsky, C.K. Shewmaker, D. Post-Beittenmiller, and H.E. Valentin. 2002. Isolation and characterization of homogentisate phytyltransferase genes from Synechocystis sp. PCC 6803 and Arabidopsis. Plant Physiolology 129:321332.

Schierholt. A., B. Rücker, and H.C. Becker. 2001. Inheritance of high oleic acid mutations in winter oilseed rape (Brassica napus L.). Crop Science 41:14441449.

Schierholt. A., H.C. Becker, and W. Ecke. 2000. Mapping a high oleic acid mutation in winter oilseed rape (Brassica napus L.). Theoretical and Applied Genetics 101:897-901.

Searle, L.M., K. Chamberlain, T. Rausch, and D.N. Butcher. 1982. The conversion of 3-indolemethylglucosinolate to 3-indoleacetonitrile by myrosinase and its relevance to the clubroot disease of the Cruciferae. Journal of Experimental Botany 33:935-942.

Selvaraj, G., R.B. Nair, R.W. Joy, J. Schnaider, X. Shi, R.S.S. Datla, and W.A. Keller. 1999. Metabolic engineering of the sinapine content of Brassica napus seeds [CD-ROM]. Proceedings of the $10^{\text {th }}$ International Rapeseed Congress, Canberra, Australia.

Shahidi, F. 1990. Canola and Rapeseed: Production, Chemistry, Nutrition and Processing technology. Van Nostrand Reinhold: New York, 355 p.

Shahidi, F., and M. Naczk. 1992. An overview of the phenolics of canola and rapeseed: chemical, sensory and nutritional implications. Journal of the American Oil Chemist's Society 69:917-924.

Shewry, P.R., J.A. Napier, and A.S. Tatham.1995. Seed Storage Protein: Structures and biosynthesis. Plant Cell 7:945-956.

Shi, C.H., J.M. Xue., Y.G.Yu., X.E. Yang, and J. Zhu. 1996. Analysis of genetic effects on nutrient quality traits in indica rice. Theoretical and Applied Genetics 92:1099-1102. 
Shintani, D., and D. DellaPenna. 1998. Elevating the vitamin E content of plants through metabolic engineering. Science 282:2098-2100.

Soll, J., G. Schultz, J. Joyard, R. Douce, and M. Block. 1985. Localization and synthesis of prenylquinones in isolated outer and inner envelope membranes from spinach chloroplasts. Archives of Biochemistry and Biophysics 238:290-299.

Soll, J., M. Kemmerling, and G. Schultz. 1980. Tocopherol and plastoquinone synthesis in spinach chloroplast subfractions. Archives of Biochemisty and Biophysics 204:544-550.

Sørensen, H. 1991. Glucosinolates: structure-properties-function. In: Shahidi. F. (eds): Canola and Rapeseed. Van Nostrand Rheinhold, New York, pp.149172.

Stefansson, B.R., and F.W. Hougen. 1964. Selection of rape plants (B. napus) with seed oil practically free from erucic acid. Canadian Journal of Plant Science 44:359-364.

Stone, W.L., and A.M. Papas. 1997. Tocopherols and the etiology of colon cancer. Journal of the National cancer institute 89:1006-1014.

Strack, D., W. Knogge, and B. Dahlbender. 1983. Enzymatic synthesis of sinapine from 1-O-sinapoyl- $\beta$-D-glucose and choline by a cell-free system from developing seeds of red radish (Raphanus sativus L. var. sativus). Zeitschrift für Naturforschung Teil C. 38:21-27.

Tan, B. 1989. Palm carotenoids, tocopherols and tocotrienols. Journal of American Oil Chemists Society 66:770-776.

Thies, W. 1988. Isolation of sinigrin and glucotropaeolin from cruciferous seeds. Fat Science and Technology 8:311-314. 
Thies, W. 1997. Entwicklung von Ausgangsmaterial mit erhöhten alpha-oder gamma-Tocopherol-Gehalten im Samenöl für die Körnerraps-Züchtung. I. Quantitative Bestimmung der Tocopherole durch HPLC. Angewandte Botanik 71: 62-67.

Thompson, J.E., C.D. Froese, E. Madey, M.D. Smith, and Y. Hong. 1998. Lipid metabolism during plant senescence. Progress in Lipid Research 37:119141.

Toroser, D., C. Thormann, T. Osborn, and R. Mithen. 1995. RFLP mapping of quantitative trait loci controlling seed aliphatic glucosinolate content in oilseed rape (Brassica napus L.). Theoretical and Applied Genetics 91:802808.

Uda, Y., T. Kurata, and N. Arakawa. 1986. Effects of $\mathrm{pH}$ and ferrous ion on the degradation of glucosinolates by myrosinase. Agricultural and Biological Chemistry 50:2735-2740.

Utz, H.F. 1997. Plabstat-Ein Computerprogramm zur statistischen Analyse von pflanzenzüchterischen Experimenten. Version 2N. Institute für Pflanzenzüchtung, Saatgutforschung und Populationsgenetik, Universität Stuttgart-Hohenheim. (http:/www.uni-hohenheim.de/-ipspwww/soft.html)

Uzunova, M., W. Ecke, K. Weissleder, and G. Röbbelen. 1995 Mapping the genome of rapeseed (Brassica napus L.) Construction of an RFLP linkage map and localization of QTLs for seed glucosinolate content. Theoretical and Applied Genetics 90:194-204.

Velasco, L., J.M. Fernández-Martínez, and A. De Haro. 2003. Inheritance of increased oleic acid concentration in high-erucic acid Ethiopian Mustard. Crop Science 43:106-109.

Vitale, A., and J. Denecke. 1999. The endoplasmic reticulum-Gateway of the secretory pathway. Plant Cell 11:615-628 
Whetten, R.W., J.J. MacKay, and R.R. Sederoff. 1998. Recent advances in understanding lignin biosynthesis. Annual Review of Plant Physiology and Plant Molecular Biolology 49:585-609.

Zhao, F., S.P. McGrath, and A.R. Crosland. 1994. Comparison of three wet digestion methods for the determination of plant sulphur by inductively coupled plasma atomic emission spectrometry (ICP-AES). Community in Soil Science and Plant Analysis 25:407-418.

Zhao, J. 2002. QTLs for oil content and their relationship to other agronomic traits in an European x Chinese population. Doctoral Dissertation, Georg-AugustUniversity Göttingen.

Zhu, J., and B.S. Weir. 1994. Analysis of cytoplasmic and maternal effects: A genetic model for diploid plant seeds and animals. Theoretical and Applied Genetics 89:153-159.

Zum Felde, T., A. Baumert, H.C. Becker, and C. Möllers. 2003. Genetic variation, inheritance and development of NIRS-calibrations for sinapic acid esters in oilseed rape (Brassica napus L.). Proceedings of the $11^{\text {th }}$ International Rapeseed Congress, Copenhagen, Denmark, pp. 271-273. 
Appendix

Manuscript I 


\section{Pollen genotype effects on seed quality traits in winter oilseed rape}

\section{Abstract}

If the pollinator genotype is of influence, this would allow to select already among individual $F_{2}$ seeds by applying single seed near-infrared reflectance spectroscopy (NIRS). The objective of this study is to determine the pollen effects on seed quality traits. Two male sterile lines (Falcon and Express) were crossed with 10 pollen parents which largely differed in seed quality. Field experiments were performed at three locations (Göttingen, Einbeck and Teendorf) in Northern Germany with two replications in the season 2002/2003. The parents were drilled in plots with normal plant density and single male sterile plants were planted by hand into the center of these plots before winter. Moreover, plots with $F_{1}$ plants were also grown to produce $F_{2}$ seed. Seeds from the parental lines, $F_{1}$ seed harvested on the interplanted male sterile plants, and $F_{2}$ seeds were analysed for of oil, protein, and sinapic acid esters contents by near-infrared reflectance spectroscopy (NIRS), for glucosinolate and tocopherol content by high-performance liquid chromatography (HPLC), and for fatty acid content by gas liquid chromatography (GLC). Results indicated that the pollinator genotype significantly influenced the $F_{1}$ seed quality for oil, indole glucosinolate, fatty acids (except linolenic acid), sinapoylglucose, sinapic acid esters, and $\gamma$-tocopherol contents. The $F_{1}$ seed quality was always positively correlated with the pollinator seed quality. Significant additive genetic effects of pollen genotype were found for indole glucosinolates, indole/aliphatic glucosinolates, fatty acids (except linolenic acid), sinapoylglucose, and sinapic acid esters. Protein, eicosenoic acid, erucic acid, sinapolyglucose, sinapine, and sinapic acid esters contents were also influenced by seed dominant effects. In conclusion, not only the fatty acids pattern, but also other quality traits are not only determined by the maternal genotype, but may be influenced by the genotype of the pollinator. This has to be considered when analysing open pollinated plants. 


\section{Introduction}

Seeds of Brassica species consist of the embryo, the endosperm and the testa or seed coat (Diepenbrock and Grosse, 1995). In the mature seed a small endosperm remains as a well-formed aleurone layer which is closely connected with the seed coat. Therefore, seed quality deferring compounds are located mainly in diploid seed cotyledons, rather than in the endosperm as typical for many monocotyledonous plants.

The knowledge of the pollen effects on seed quality traits are very limited in oilseed rape, except for the fatty acids composition. For fatty acids like erucic acid (C22:1) and oleic acid (C18:1), it is well-known that their content is determined by the genotype of the embryo (Downey and Craig, 1964; Scarth and McVetty, 1999; Schierholt et al., 2001). However, experimental knowledge on the pollen influence on other seed quality traits is very limited. It is often assumed, that most oilseed rape quality traits like oil, protein and glucosinolate content are only determined by the genotype of the maternal plant on which the seeds are grown and not influenced by the genotype of the pollinator. If the pollinator genotype is of influence, this would allow to select already among individual $F_{2}$ seeds by applying single seed nearinfrared reflectance spectroscopy (NIRS). On the other hand, a pollinator influence would confound the results when analysing seeds from open pollinated plants. The main objective of this study is to determine the pollen effects on seed quality traits. $A$ more specific objective is to investigate whether there is a relationship between increasing oil content and high erucic acid.

\section{Materials and Methods}

\section{Plant materials and field experiments}

Ten different pollen genotypes of winter oilseed rape were chosen and crossed with two male sterile (MS) females (Falcon and Express) (Table 1). Each pollen parent and the two MS lines were grown together under isolation and pollinated by help of honey bees to produce $F_{1} s$ in the field at Reinshof, Göttingen in the season $2001 / 2002$. 
Table 1. Pollen parents used.

\begin{tabular}{cll}
\hline Line no. & Genotype & Type of quality \\
\hline 1 & DH-7 (Apex x Mohican) & Low oil \\
2 & H-48 & Low oil, High GSL \\
3 & Express & Standard \\
4 & DH-1 (Apex x Mohican) & High oil \\
5 & DH-09 (Mansholts x Samourai) & High GSL, High C22:1 \\
6 & H-10 & High GSL, High C22:1 \\
7 & $1636-3$ & Very low GSL \\
8 & $1684-2$ & Very low GSL \\
9 & 5297 & High C18:1 \\
10 & Falcon & Standard \\
\hline
\end{tabular}

In the season 2002/2003 a field experiment was performed at three locations with two replications. For each pollen parent a block with seven plots was grown containing three plots of at least $10.5 \mathrm{~m}^{2}$ plot size (Figure 1). Ten single plants of each of the two female MS parents were transplanted into the center of these plots before winter. With this design, seed of the following generations were produced: pollen parents (harvesting plants in the center of the parental plots), $F_{1}$ (harvesting the female MS plants), and $F_{2}$ (harvesting plants in the center of the $F_{1}$ plots) (Table 2). At maturity, seeds were harvested separately from 5 plants each of pollen parents and $F_{1}$ and 10 plants of $F_{2}$.

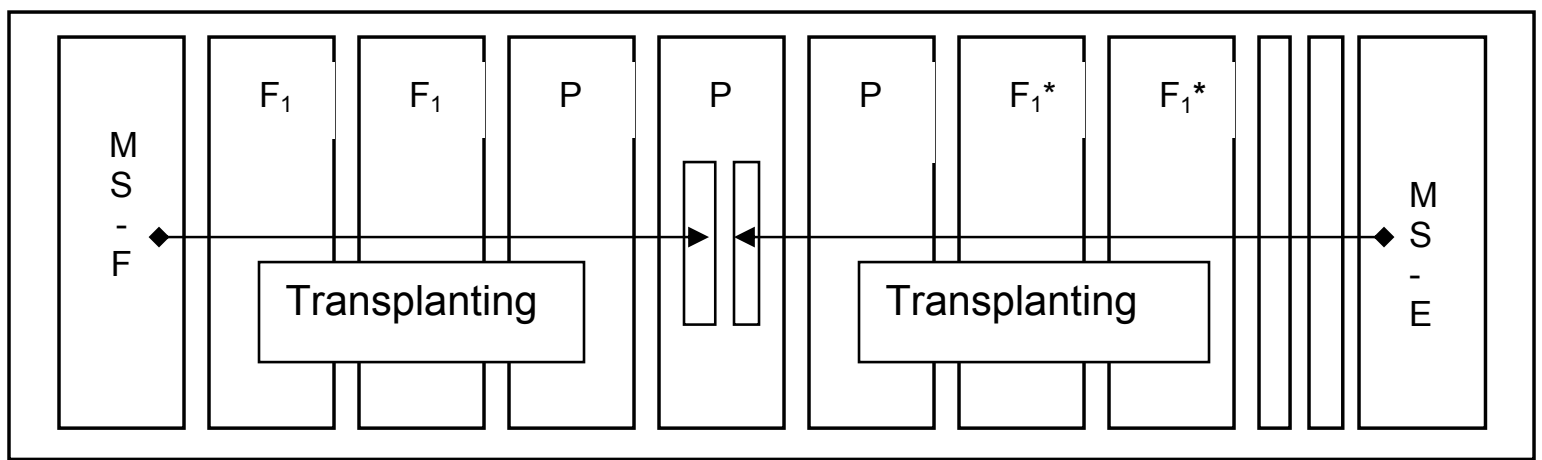

Figure 1. Crossing block design (MS - F and MS - E = Male sterile Falcon and Express). 
Table 2. Seed generations produced from each pollen parent in the crossing block.

\begin{tabular}{ccc}
\hline Female & Male & Seeds \\
\hline P & $\mathrm{P}$ & $\mathrm{P}$ \\
MS Falcon & $\mathrm{P}$ & $\mathrm{F} 1$ \\
MS Express & $\mathrm{P}$ & $\mathrm{F} 1^{*}$ \\
$\mathrm{~F} 1$ & $\mathrm{~F} 1$ & $\mathrm{~F} 2$ \\
$\mathrm{~F}^{*}$ & $\mathrm{~F} 1^{*}$ & $\mathrm{~F} 2^{*}$ \\
\hline
\end{tabular}

\section{Observed traits and analytical methods for seed quality}

The parental, $F_{1}$ and $F_{2}$ seeds were scanned with NIRS monochromator model Foss 6500 using Raps2001.eqa (Tillmann, 2004) for oil and protein contents, and sin03n65.eqa (Zum Felde, University of Göttingen) for sinapic acid esters (sinapoylglucose, sinapine, rest of sinapic acid esters, and total of sinapic acid esters).

High-performance liquid chromatography (HPLC) method, which involved the adsorption of glucosinolate onto small columns of anion-exchange material and washing with water followed by treatment with the enzyme sulphatase for analysing of each constituent glucosinolate was adopted as an official method of the European Commission (EC, 1990) (Spinks, et al., 1984; Rosa, 1999). The glucosinolate (GSL) content and the components of GSL were analysed by HPLC method by using the internal standard solution which was isolated according to Thies (1988). Tocopherols were analysed by HPLC standard reference methods (Thies, 1997). For tocopherols only four parents, the two highest (parents 4 and 5, Table 1) and the two lowest (parents 6 and 9 ) in $\alpha / \gamma$-tocopherol content and their $F_{1} s$ with the two male sterile females were analysed. Fatty acid composition of the samples was determined by Gas Liquid Chromatography (GLC) (Thies, 1971). 


\section{Statistical analysis}

\section{Analysis of variance}

The analysis of variance was performed by PLABSTAT, version 2N (Utz, 1997) using the following model:

$Y_{i j k l}=\mu+m_{i}+f_{j}+e_{k}+(m f)_{i j}+(m e)_{i k}+(f e)_{j k}+(m f e)_{i j k}+r_{k l}+\varepsilon_{i j k l}$

$\mathrm{Y}_{\mathrm{ijkl}}=$ the observation of male genotype $\mathrm{i}$ and female genotype $\mathrm{j}$ in environment $\mathrm{k}$ and replication $\mathrm{I} ; \mu=$ the over all mean; $\mathrm{m}_{\mathrm{i}}=$ the effect of male pollen parent $\mathrm{i}=1, \ldots, M ; \mathrm{f}_{\mathrm{j}}$ is the effect of female parent $\mathrm{j}=1, \ldots, \mathrm{F} ; \mathrm{e}_{\mathrm{k}}=$ effect of environment $\mathrm{k}=1, \ldots, \mathrm{E} ;(\mathrm{mf})_{\mathrm{ij}}$ $=$ interaction effect of male pollen parent $\mathrm{i}$ and female parent $\mathrm{j} ;(\mathrm{me})_{\mathrm{ik}}=$ interaction effect of male pollen parent $\mathrm{i}$ and environment $\mathrm{k}$; $(\mathrm{fe})_{\mathrm{jk}}=$ interaction effect of female $\mathrm{j}$ and environment $\mathrm{k} ;(\mathrm{mfe})_{\mathrm{ijk}}=$ interaction effect of male pollen parent $\mathrm{i}$, female parent $\mathrm{j}$, and environment $\mathrm{k} ; \mathrm{r}_{\mathrm{kl}}=$ effect of replication $\mathrm{I}$ in the environment $\mathrm{k}(\mathrm{I}=1, \ldots, \mathrm{R}) ; \varepsilon_{\mathrm{ijkl}}=$ residual error of male $\mathrm{i}$ and female $\mathrm{j}$ at environment $\mathrm{k}$ in replication $\mathrm{I}$. The factors $\mathrm{e}$ and $r$ were considered random.

\section{Estimation of genetic effects on seed quality traits}

The mean value of parents, $F_{1} S$ and $F_{2} S$ from each location were used for the estimation of the genetic effects. The genetic model for diploid seeds with a MINQUE (0/1) with jack-knife procedure method (Zhu and Weir, 1994) was used to estimate genetic components of seed additive $\left(\mathrm{V}_{\mathrm{A}}\right)$ and dominance $\left(\mathrm{V}_{\mathrm{D}}\right)$ variance, maternal additive $\left(\mathrm{V}_{\mathrm{Am}}\right)$ and dominance $\left(\mathrm{V}_{\mathrm{Dm}}\right)$ variance, cytoplasmic variance $\left(\mathrm{V}_{\mathrm{C}}\right)$, and covariances between seed and maternal effects $\left(C_{A . A m}\right)$ and between seed and maternal dominance effects $\left(C_{D . D m}\right)$. Moreover, variance of interaction between genetic components and environment $(E)$ were estimated for seed additive $x$ environment $\left(\mathrm{V}_{\mathrm{AE}}\right)$, dominance $x$ environment $\left(\mathrm{V}_{\mathrm{DE}}\right)$, maternal additive $\left(\mathrm{V}_{\mathrm{AmE}}\right)$, maternal dominance $\left(V_{D m E}\right)$, cytoplasmic $x$ environment $\left(V_{C E}\right)$, covariance between seed and maternal additive effects with environment $\left(C_{A E . A m E}\right)$, and between seed and maternal dominance $\left(\mathrm{C}_{\mathrm{DE} \cdot \mathrm{DmE}}\right)$. 


\section{Results}

Means values of pollen parents, $F_{1} s$, and $F_{2} s$ for oil and protein contents

Mean values of pollen parents and their $F_{1} s$ and $F_{2} s$ for oil and protein contents are shown in Table 3. Even though the female parents were the same for all crosses, values for $F_{1} s$ and $F_{2} s$ showed a considerable variation in oil and protein contents. The pollen parents with highest or lowest oil content (5297 and $\mathrm{H}-48$, respectively) had $F_{1} s$ and $F_{2} s$ which were also high or low in oil content.

\section{Analysis of variance}

The results from the analysis of variance are presented in Table 4, 5, 6, 7 and 8.

\section{Male pollen parent effects}

For male pollen parent $(M)$ effects, analysis of variance of $F_{1} s$ showed highly significant $(P=0.01)$ values for oil content, indole glucosinolate content, oleic (C18:1), linoleic (C18:2), eicosenoic (C20:1), and erucic acid (C22:1).

Significant differences $(P=0.05, P=0.10)$ for male pollen parent $(\mathrm{M})$ were found for indole/aliphatic glucosinolates, linolenic acid (C18:3), and MUFA (C18:1+ C20:1+ C22:1) in fatty acids, sinapoylglucose (SinGI) and $\alpha / \gamma$-tocopherol.

\section{Female parent effects}

The mean squares for variance between the two female parents (Falcon and Express) were significant in protein $(P=0.10)$ and in most of fatty acids, stearic, oleic, linoleic, linolenic, and MUFA. Moreover, strong significant differences were found in sinapic acid esters and tocopherol contents.

\section{Environmental effects}

Significant effect of environment $(E)$ was found in aliphatic GSL, palmitic $(P=0.01)$, stearic, linolenic, and erucic acids, sinapic acid esters, $\alpha / \gamma$-tocopherol. In addition, slightly significant $(P=0.10)$ effects were found in protein, indole/ aliphatic GSL, oleic acid, and $\gamma$ - tocopherol. 


\section{Environment x Male}

Interaction between environment $(E)$ and male pollen parent (M) showed highly significant effects $(P=0.01)$ in oil, protein, palmitic acid, stearic acid, linoleic acid, eicosenoic acid, erucic acid and MUFA, and in sinapic acid esters (sinapine, rest, and total content).

Furthermore, significant effects $(P=0.05)$ for interaction between male pollen parent and environment $(\mathrm{M} \times \mathrm{E})$ were observed in indole/aliphatic glucosinolate, oleic acid, and sinapoylglucose. A slightly but significant effect $(P=0.10)$ was found in aliphatic glucosinolate, and linolenic.

Table 3. Comparison of the mean values of pollen parents, $F_{1} s$ and $F_{2} s$ for oil and protein contents.

\begin{tabular}{|c|c|c|c|c|c|c|c|c|c|c|}
\hline \multirow{2}{*}{ Pollen parents } & \multicolumn{5}{|c|}{ Oil (\%) } & \multicolumn{5}{|c|}{ Protein(\%) } \\
\hline & $\mathrm{P}$ & $\mathrm{F}_{1}$ & $\mathrm{~F}_{1}^{*}$ & $\mathrm{~F}_{2}$ & $\mathrm{~F}_{2}^{*}$ & $\mathrm{P}$ & $\mathrm{F}_{1}$ & $\mathrm{~F}_{1}^{*}$ & $\mathrm{~F}_{2}$ & $\mathrm{~F}_{2}^{*}$ \\
\hline 1. DH-7(Apex x Mohican) & 48.5 & 50.0 & 51.0 & 51.3 & 50.3 & 20.0 & 18.4 & 19.3 & 18.3 & 17.9 \\
\hline 2. $\mathrm{H}-48$ & 45.3 & 49.6 & 50.1 & - & 49.3 & 20.6 & 18.8 & 19.9 & - & 19.3 \\
\hline 3. Express & 51.9 & 50.5 & 50.4 & 51.2 & 50.3 & 18.6 & 18.4 & 20.2 & 18.5 & 18.0 \\
\hline 4. DH-1(Apex x Mohican) & 53.9 & 50.3 & 49.9 & 51.3 & 51.3 & 16.5 & 18.5 & 20.9 & 17.3 & 16.9 \\
\hline 5. DH-09(Mansholts $\times$ Samourai) & 52.3 & 53.9 & 53.2 & 52.4 & 53.1 & 20.2 & 18.0 & 20.3 & 18.4 & 17.3 \\
\hline 6. $\mathrm{H}-10$ & 47.1 & 51.7 & 50.8 & 50.9 & 50.9 & 24.0 & 19.1 & 21.4 & 19.6 & 19.7 \\
\hline 7. $1636-3$ & 48.0 & 50.6 & 50.7 & 51.0 & 51.3 & 20.2 & 18.4 & 19.8 & 18.7 & 17.8 \\
\hline 8. $1684-2$ & 47.2 & 49.1 & 49.5 & 50.0 & 48.1 & 19.8 & 18.9 & 20.2 & 18.4 & 19.1 \\
\hline 9. 5297 & 54.6 & 51.5 & 51.4 & 53.0 & 52.0 & 15.8 & 17.4 & 19.4 & 16.9 & 16.6 \\
\hline 10. Falcon & 50.3 & 48.6 & 49.1 & 51.5 & 49.5 & 18.1 & 19.6 & 20.6 & 17.8 & 18.5 \\
\hline
\end{tabular}


Table 4. Mean squares (MQ) and variance components of the analysis of variance of $F_{1}$ for oil and protein contents.

\begin{tabular}{lrrrrr}
\hline \multirow{2}{*}{ Genotype } & DF & \multicolumn{2}{c}{ Oil } & \multicolumn{2}{c}{ Protein } \\
\cline { 3 - 6 } & & \multicolumn{1}{c}{ MQ } & Var.com & MQ & Var.com \\
\hline Male (M) & 9 & $20.4^{\star *}$ & 1.34 & 3.6 & 0.10 \\
Female (F) & 1 & 0.0 & -0.35 & $82.4^{+}$ & 1.25 \\
Environment (E) & 2 & 19.8 & 0.26 & $79.2^{+}$ & 1.69 \\
M x F & 9 & 1.2 & 0.02 & 1.0 & 0.06 \\
M x E & 18 & $4.4^{\star *}$ & 0.80 & $2.4^{\star *}$ & 0.36 \\
F x E & 2 & $21.3^{* *}$ & 1.01 & $7.4^{* *}$ & 0.32 \\
M x F x E & 18 & 1.0 & -0.07 & 0.7 & -0.14 \\
\hline
\end{tabular}

$+,{ }^{*},{ }^{* *}=$ significantly different at $P=0.10,0.05$, and 0.01 , respectively.

Table 5. Mean squares (MQ) and variance components of the analysis of variance of $\mathrm{F}_{1}$ for glucosinolate (GSL) content.

\begin{tabular}{|c|c|c|c|c|c|c|c|c|c|}
\hline \multirow{2}{*}{ Genotype } & \multirow{2}{*}{ DF } & \multicolumn{2}{|c|}{ Indole } & \multicolumn{2}{|c|}{ Aliphatic } & \multicolumn{2}{|c|}{ Indole/Aliphatic } & \multicolumn{2}{|c|}{ Total } \\
\hline & & $M Q$ & Var.com & $\mathrm{MQ}$ & Var.com & $\mathrm{MQ}$ & Var.com & $\mathrm{MQ}$ & Var.com \\
\hline Male (M) & 9 & $4.7^{* \star}$ & 0.319 & 9.2 & 0.08 & $0.05^{*}$ & 0.0032 & 18.9 & 0.78 \\
\hline Female (F) & 1 & 4.7 & 0.067 & 55.5 & 0.59 & 0.02 & -0.0001 & 84.8 & 1.19 \\
\hline Environment (E) & 2 & 9.3 & 0.082 & $187.5^{*}$ & 4.41 & $0.38^{+}$ & 0.0085 & 111.9 & 2.12 \\
\hline$M \times F$ & 9 & 0.5 & 0.004 & 1.2 & -0.36 & 0.00 & -0.0002 & 3.7 & -0.16 \\
\hline$M \times E$ & 18 & 1.1 & -0.006 & $8.2^{+}$ & 0.85 & $0.02^{*}$ & 0.0019 & 9.5 & 0.02 \\
\hline$F \times E$ & 2 & 0.7 & -0.021 & $20.1^{*}$ & 0.76 & $0.03^{+}$ & 0.0009 & 13.5 & -0.16 \\
\hline$M \times F \times E$ & 18 & 0.5 & -0.306 & 3.4 & -0.74 & 0.01 & -0.0017 & 4.7 & -2.37 \\
\hline
\end{tabular}

$+,{ }^{*},{ }^{* *}=$ significantly different at $P=0.10,0.05$, and 0.01 , respectively. 
Table 6. Mean squares (MQ) and variance components of the analysis of variance of $F_{1}$ for fatty acids content.

\begin{tabular}{|c|c|c|c|c|c|c|c|c|c|c|c|}
\hline \multirow{2}{*}{ Genotype } & \multirow{2}{*}{ DF } & \multicolumn{2}{|c|}{ Palmitic (C16:0) } & \multicolumn{2}{|c|}{ Stearic (C18:0) } & \multicolumn{2}{|c|}{ Oleic (C18:1) } & \multicolumn{2}{|c|}{ Linoleic (C18:2) } & \multicolumn{2}{|c|}{ Linolenic (C18:3) } \\
\hline & & $M Q$ & Var.com & $M Q$ & Var.com & $M Q$ & Var.com & $M Q$ & Var.com & $M Q$ & Var.com \\
\hline Male (M) & 9 & $0.21^{+}$ & 0.009 & $1.33^{+}$ & 0.066 & $1060.7^{\star *}$ & 87.20 & $27.2^{\star *}$ & 1.73 & $1.19^{*}$ & 0.08 \\
\hline Female (F) & 1 & $9.61^{* *}$ & 0.160 & $0.39^{*}$ & 0.006 & $605.1^{*}$ & 9.63 & $329.9^{*}$ & 5.31 & $9.68^{+}$ & 0.15 \\
\hline Environment (E) & 2 & $2.00^{\star *}$ & 0.050 & $5.58^{*}$ & 0.125 & $166.5^{+}$ & 3.50 & 3.3 & -0.06 & $13.26^{*}$ & 0.31 \\
\hline$M \times F$ & 9 & 0.65 & 0.006 & $0.03^{+}$ & 0.002 & 6.2 & -1.40 & 4.2 & -0.38 & 0.28 & -0.04 \\
\hline$E \times M$ & 18 & $0.10^{* *}$ & 0.017 & $0.55^{\star *}$ & 0.121 & $14.3^{*}$ & 2.01 & $6.4^{* *}$ & 1.13 & $0.50^{+}$ & 0.05 \\
\hline$E \times F$ & 2 & 0.02 & -0.001 & 0.02 & -0.002 & $27.2^{*}$ & 1.05 & $11.3^{* *}$ & 0.47 & $0.79^{+}$ & 0.02 \\
\hline$E \times M \times F$ & 18 & 0.04 & 0.001 & 0.01 & -0.026 & $14.6^{*}$ & 4.15 & $6.7^{* *}$ & 2.41 & $0.55^{+}$ & 0.12 \\
\hline
\end{tabular}

$+,{ }^{*},{ }^{* *}=$ significantly different at $P=0.10,0.05$, and 0.01 , respectively. 
Table 6 (continued). Mean squares (MQ) and variance components of the analysis variance of $F_{1}$ for fatty acids content.

\begin{tabular}{|c|c|c|c|c|c|c|c|}
\hline \multirow{2}{*}{ Genotype } & \multirow{2}{*}{ DF } & \multicolumn{2}{|c|}{ Eicosenoic (C20:1) } & \multicolumn{2}{|c|}{ Erucic (C22:1) } & \multicolumn{2}{|c|}{ MUFA (C18:1+C20:1+C22:1) } \\
\hline & & $M Q$ & Var.com & $M Q$ & Var.com & $M Q$ & Var.com \\
\hline Male (M) & 9 & $199.1^{* *}$ & 16.3787 & $281.2^{* *}$ & 23.07 & $38.0^{*}$ & 2.20 \\
\hline Female $(F)$ & 1 & 2.0 & 0.0294 & 5.4 & 0.07 & $561.9^{*}$ & 9.09 \\
\hline Environment $(\mathrm{E})$ & 2 & 8.0 & 0.1365 & $17.8^{*}$ & 0.42 & 35.7 & 0.52 \\
\hline$M \times F$ & 9 & $1.8^{*}$ & 0.2047 & 1.3 & -0.03 & 7.0 & -0.62 \\
\hline$E \times M$ & 18 & $2.6^{* *}$ & 0.5012 & $4.3^{* *}$ & 0.87 & $11.6^{* *}$ & 1.94 \\
\hline$E \times F$ & 2 & 0.3 & -0.0160 & 1.3 & 0.03 & $16.4^{*}$ & 0.63 \\
\hline$E \times M \times F$ & 18 & 0.9 & -0.0003 & $1.4^{*}$ & 0.33 & $10.7^{\star *}$ & 3.45 \\
\hline
\end{tabular}

$+,{ }^{*},{ }^{* *}=$ significantly different at $P=0.10,0.05$, and 0.01 , respectively. 
Table 7. Mean squares (MQ) and variance components of the analysis of variance of $F_{1}$ for sinapic acid esters (SAE) content.

\begin{tabular}{lcccccccccc}
\hline \multirow{2}{*}{ Genotype } & & \multicolumn{2}{c}{ SinGI } & \multicolumn{2}{c}{ Sinapine } & \multicolumn{2}{c}{ Rest } & \multicolumn{2}{c}{ Total } \\
\cline { 3 - 10 } & & MQ & Var.com & MQ & Var.com & MQ & Var.com & MQ & Var.com \\
\hline Male (M) & 9 & $0.78^{*}$ & 0.042 & 0.4 & -0.0378 & 0.23 & 0.007 & 1.4 & 0.056 \\
Female (F) & 1 & $27.7^{* *}$ & 0.460 & $65.3^{\star *}$ & 1.0859 & $2.34^{* *}$ & 0.039 & $1.1^{*}$ & 0.017 \\
Environment (E) & 2 & $7.5^{* *}$ & 0.188 & $10.1^{* *}$ & 0.2430 & $1.39^{*}$ & 0.033 & $10.2^{* *}$ & 0.251 \\
M x F & 9 & 0.1 & 0.006 & $0.2^{+}$ & 0.0203 & 0.02 & 0.001 & 0.2 & 0.010 \\
M x E & 18 & $0.3^{*}$ & 0.034 & $0.9^{* *}$ & 0.1749 & $0.14^{* *}$ & 0.030 & $0.8^{* *}$ & 0.147 \\
FxE & 2 & 0.2 & 0.002 & 0.2 & 0.0003 & 0.01 & -0.001 & 0.1 & -0.006 \\
M x FxE & 18 & 0.1 & -0.024 & 0.1 & -0.0365 & 0.02 & -0.001 & 0.1 & -0.033 \\
\hline
\end{tabular}

$+,{ }^{*},{ }^{* *}=$ significantly different at $P=0.10,0.05$, and 0.01 , respectively.

Table 8. Mean squares (MQ) and variance components of the analysis of variance of $F_{1}$ for tocopherol content.

\begin{tabular}{|c|c|c|c|c|c|c|c|c|c|}
\hline \multirow{2}{*}{ Genotype } & \multirow{2}{*}{ DF } & \multicolumn{2}{|c|}{$\alpha$-TOC } & \multicolumn{2}{|c|}{$\gamma$-TOC } & \multicolumn{2}{|c|}{$\alpha / \gamma$ TOC } & \multicolumn{2}{|c|}{ Total } \\
\hline & & $M Q \quad V$ & Var.com & $M Q$ & Var.com & $M Q$ & Var.com & $M Q$ & Var.com \\
\hline Male (M) & 3 & 46.6 & 2.48 & $493.5^{+}$ & 31.48 & $0.0058^{*}$ & 0.0004 & 559.9 & 30.41 \\
\hline Female (F) & 1 & $1564.1^{* *}$ & ** 64.65 & $3570.8^{* *}$ & 148.22 & 0.0073 & 0.0002 & $10472.5^{* *}$ & 435.51 \\
\hline Environment (E) & 2 & 1.6 & -3.54 & $1575.1^{+}$ & 85.07 & $0.0119^{*}$ & 0.0007 & 2045.9 & 100.41 \\
\hline$M \times F$ & 3 & 3.4 & -1.14 & 103.6 & 2.80 & 0.0006 & 0.0000 & 114.4 & -2.82 \\
\hline$M \times E$ & 6 & 16.8 & -0.23 & 115.7 & 12.59 & 0.0009 & 0.0002 & 195.0 & 15.49 \\
\hline$F \times E$ & 2 & 12.6 & -0.64 & 13.6 & -6.48 & 0.0012 & 0.0001 & 20.3 & -14.09 \\
\hline$M \times F \times E$ & 6 & 61.5 & 10.25 & 86.8 & 10.72 & 0.0003 & 0.0000 & 131.3 & -0.83 \\
\hline
\end{tabular}

$+,{ }^{*},{ }^{* *}=$ significantly different at $P=0.10,0.05$, and 0.01 , respectively. 


\section{Correlation coefficients}

Positive correlations between pollen parents and their $F_{1} s$ were found for oil and protein contents (Figure 2). Results for glucosinolate (GSL) indicated that there were highly significant correlations $(P=0.01)$ in indole glucosinolate content and indole/aliphatic glucosinolate content between pollen parents and their $\mathrm{F}_{1} \mathrm{~s}$ (Figure 3). In the components of glucosinolate, positive significant correlation was found for sinigrin (SIN) $\left(r=0.61^{+}\right)$, gluconapoleiferin $(G N L)\left(r=0.85^{* *}\right)$, 4-hydroxyglucobrassicin $(4 \mathrm{OH})$, and for indole glucosinolate $\left(r=0.74^{*}\right)$.

For fatty acids content, highly positive significant correlation $(P=0.01)$ was found in stearic acid (C18:0), oleic acid (C18:1), linoleic acid (C18:2), eicosenoic acid (C20:1), erucic acid (C22:1), and MUFA (C18:1 + C20:1 + C22:1). Moreover, palmitic acid $(C 16: 0)$ showed positively significant correlation $(P=0.05)$ (Figure 4$)$. Sinapic acid esters (SAE) content in seed showed positive correlation between pollen parents and their $F_{1} s$ in all components (Figure 5$)$. Highly significant correlation $\left(r=0.82^{* *}\right)$ was found in rest of SAE content, significant correlation $\left(r=0.63^{*}\right)$ was observed in sinapoylglucose $(\operatorname{SinGl})$ and in total SAE $\left(r=0.62^{+}\right)$, respectively. There was a positive correlation, but not significant correlation showed in sinapine (Sinap) ( $r=0.51)$.

(a) Oil content (\%)

(b) Protein content $(\%)$

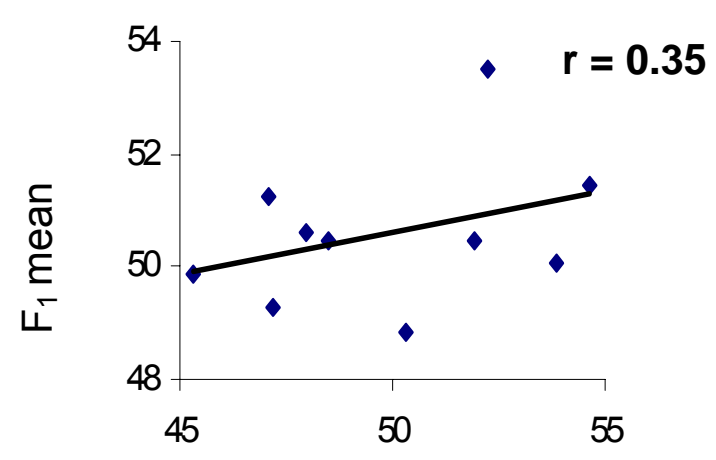

Pollen parents

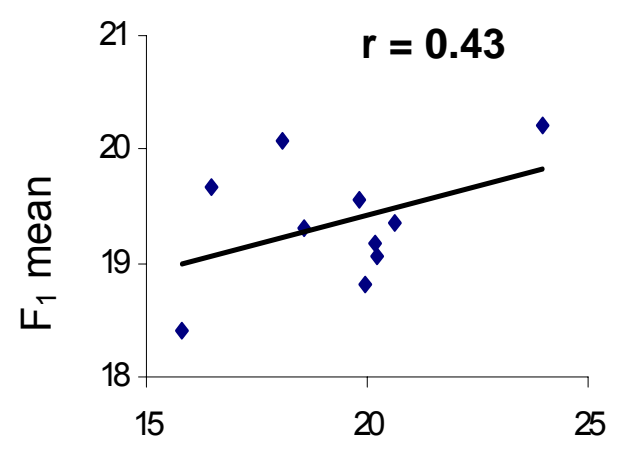

Pollen parents

Figure 2. Correlation between pollen parents and their $F_{1} s$ in oil and protein contents, (a) oil content (b) protein content. 
(a) Indole GSL ( $\mu \mathrm{mol} / \mathrm{g})$

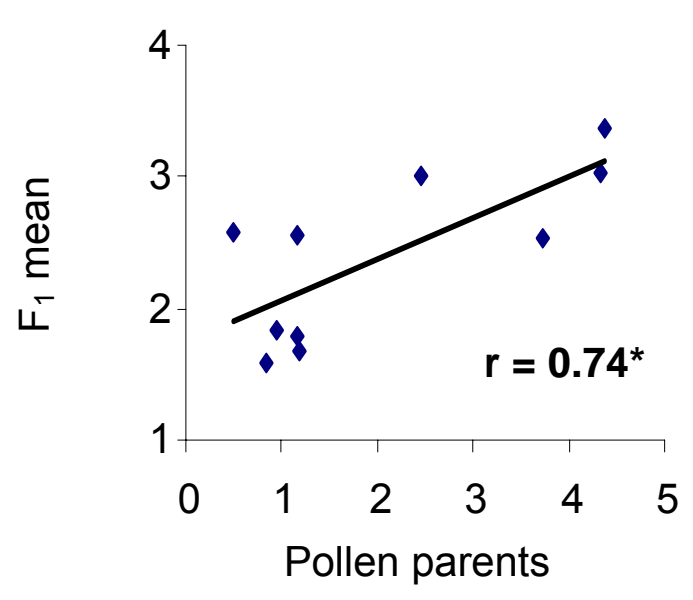

(c) Indole/Aliphatic GSL ( $\mu \mathrm{mol} / \mathrm{g})$

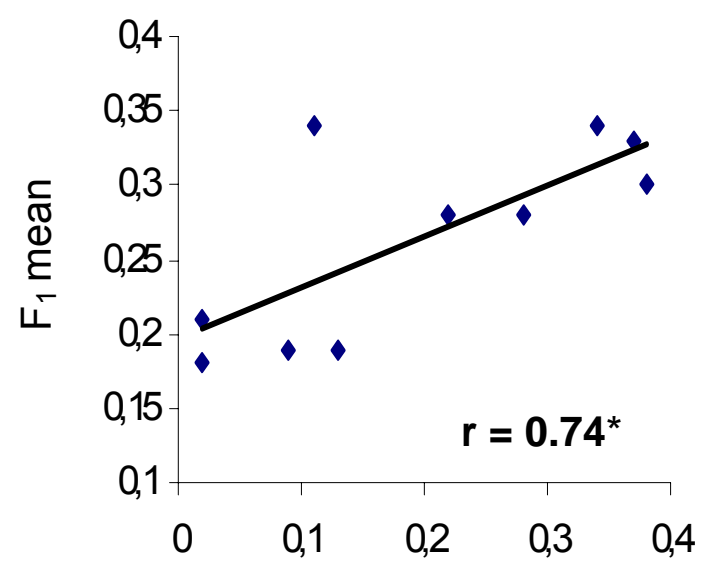

Pollen parents (b) Aliphatic GSL ( $\mu \mathrm{mol} / \mathrm{g})$

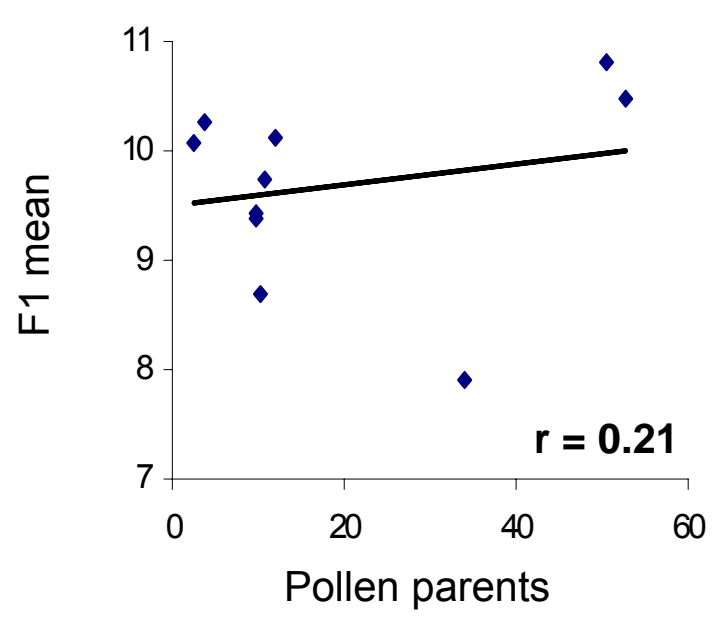

(d) Total GSL $(\mu \mathrm{mol} / \mathrm{g})$

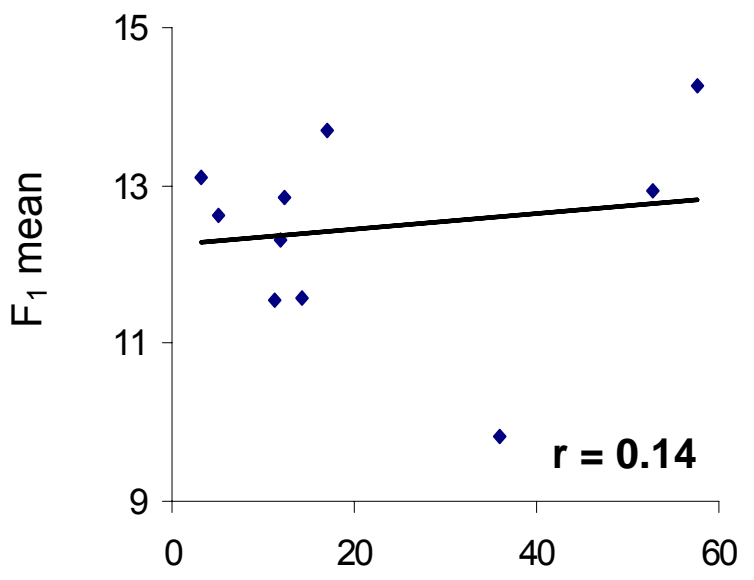

Pollen parents

Figure 3. Correlation between pollen parents and their $F_{1} s$ in glucosinolate (GSL), (a) indole GSL, (b) aliphatic GSL, (c) indole/aliphatic GSL, (d) total GSL. 
(a) Palmitic acid

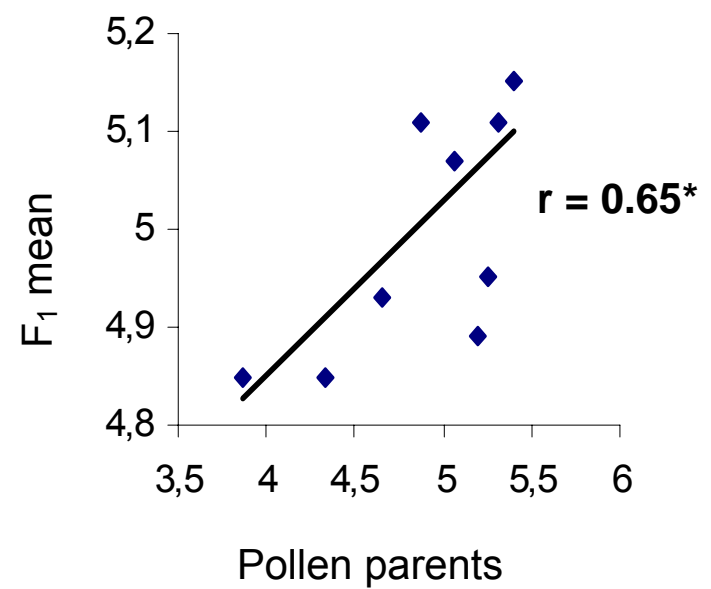

(c) Oleic acid

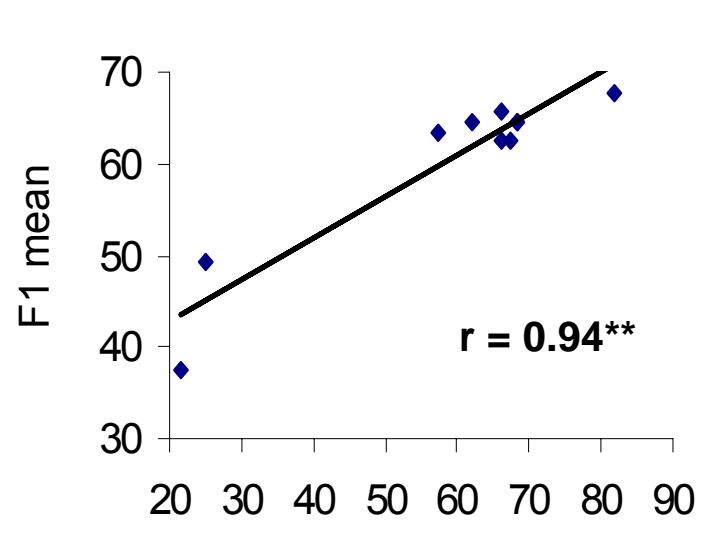

Pollen parents (b) Stearic acid

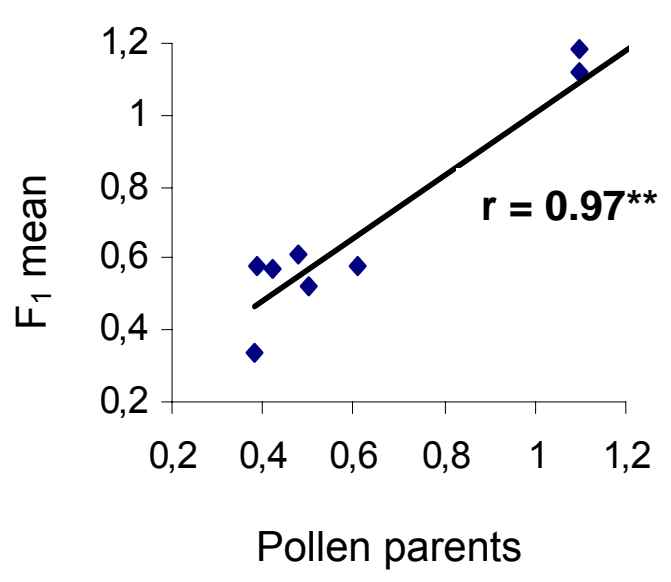

(d) Linoleic acid

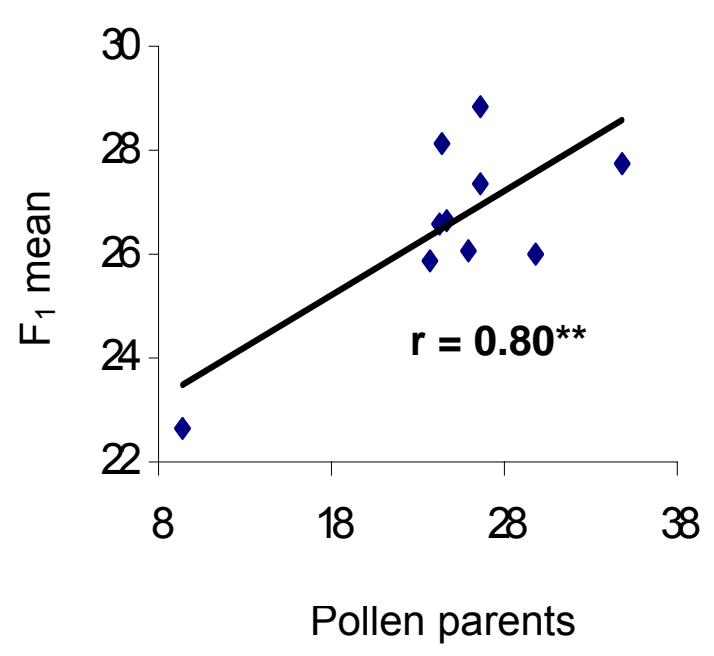

Figure 4. Correlation between pollen parents and their $F_{1} s$ in fatty acids content (a) palmitic acid, (b) stearic acid, (c) oleic acid, (d) linoleic acid. 
(e) Linolenic acid (\%)

(f) Eicosenoic acid (\%)

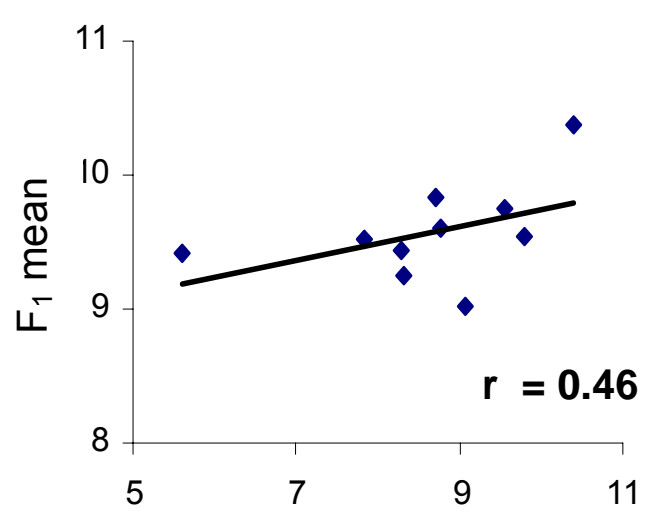

Pollen parents

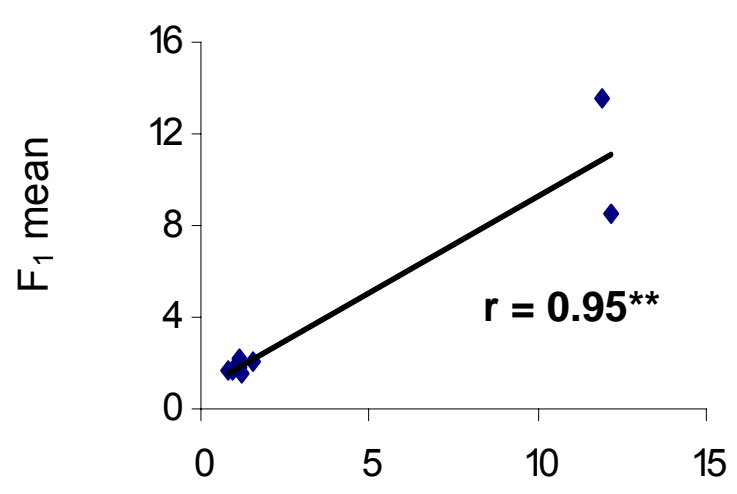

Pollen parents

(g) Erucic acid (\%)

(h) MUFA (\%)
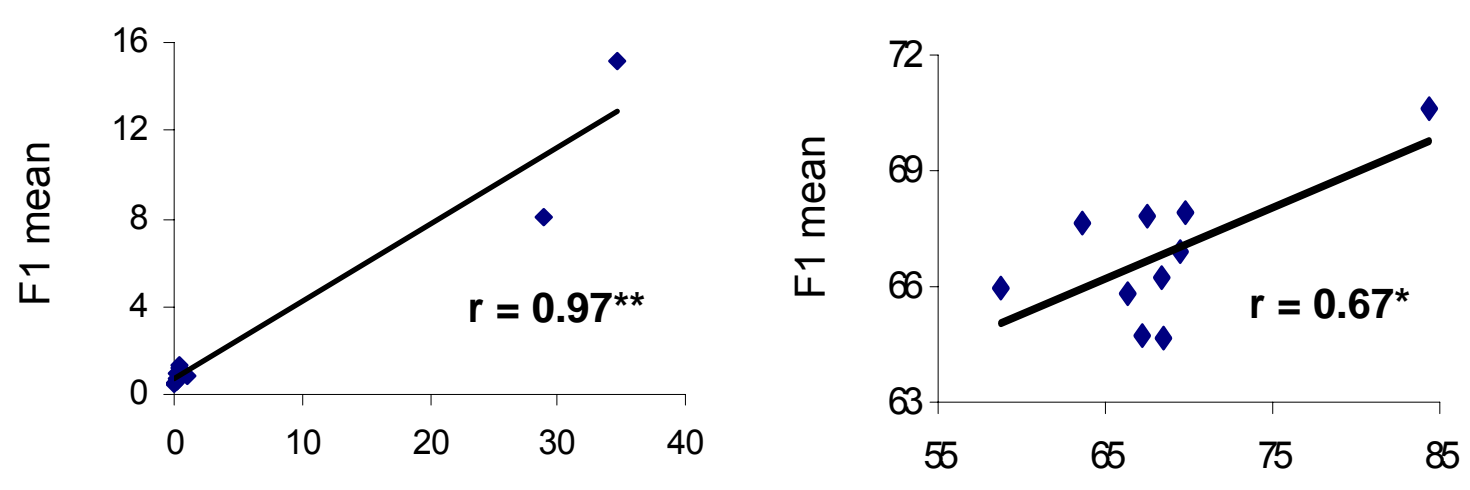

Pollen parents

Pollen parents

Figure 4 (continued). Correlation between pollen parents and their $F_{1} s$ in fatty acids content (e) linolenic acid, (f) eicosenoic acid, (g) erucic acid, (h) MUFA. 
(a) Sinapoylglucose $(\mathrm{mg} / \mathrm{g})$

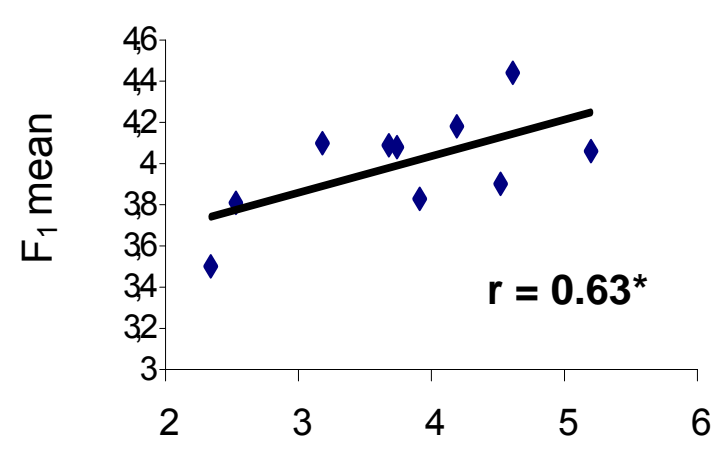

Pollen parents

(c) Rest of SAE (mg/g)

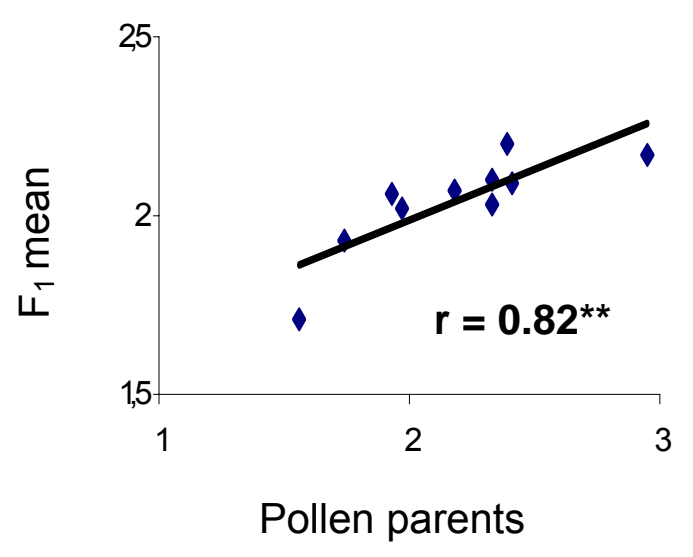

(b) Sinapine (mg/g)

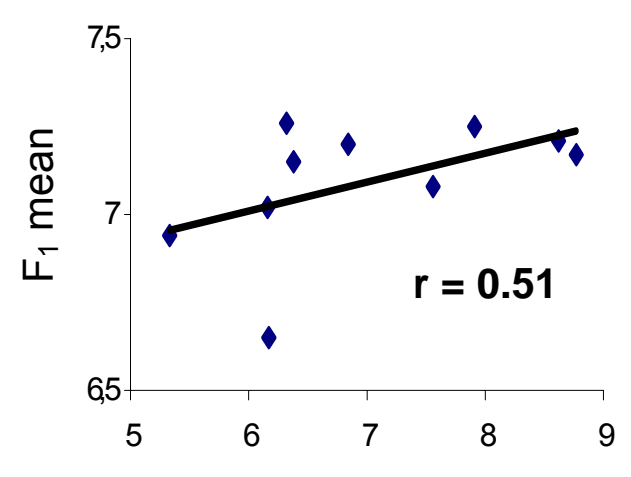

Pollen parents

(d) Total SAE (mg/g)

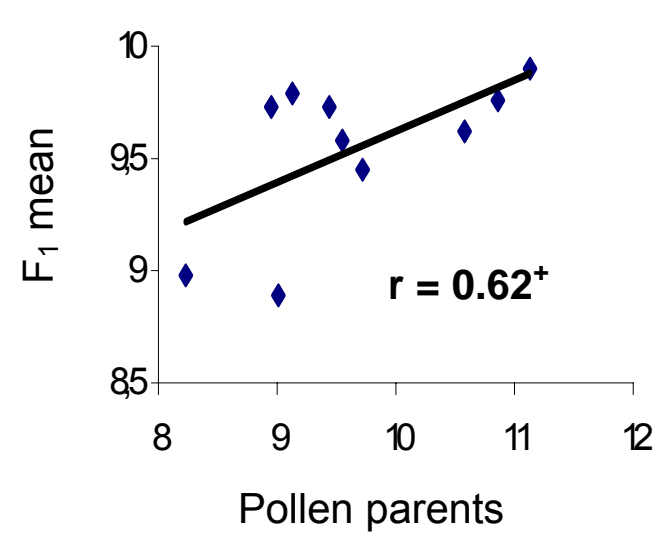

Figure 5. Correlation between pollen parents and their $F_{1} s$ in sinapic acid ester (SAE) content (a) sinapoylglucose, (b) sinapine, (c) rest of SAE, (d) total SAE. 


\section{Estimation of the genetic effects on seed quality traits}

Estimation of variance and covariance components for genetic effects and interaction of genotype and environment effects for oil, protein, glucosinolate, and fatty acids contents are described in Table 9 and 10. Except for protein, linolenic acid, sinapine and total sinapic acid esters (SAE), variance of seed direct additive effects $\left(V_{A}\right)$ were significant in all quality traits. Variance of seed direct dominance effects $\left(V_{D}\right)$ was significant for protein, eicosenoic acid (C20:1), erucic acid (C22:1), and sinapic acid esters contens. Variance of cytoplasimc effects $\left(V_{C}\right)$ was found in all quality traits, except for aliphatic glucosinolate, total glucosinolate, eicosenoic acid, sinapine and total sinapic acid esters.

Variance of maternal additive effects was significant in oil, protein, indole glucosinolate, aliphatic glucosinolate, total glucosinolate, oleic acid (C18:1) contents and in all SAE. Positive covariance of additive effects $\left(C_{A . A m}\right)$ was detected only in oil content. Total sinapic acid ester (SAE) showed highly significant covariance dominant effect $\left(C_{\text {D.Dm }}\right)$. Therefore, covariance effects are not important for other quality traits.

There were significant $\mathrm{V}_{\mathrm{AE}}$ in indole glucosinolate, aliphatic glucosinolate, and in oleic (C18:1), eicosenoic acid (C20:1) and erucic acid (C22:1) contents. The significance of $\mathrm{V}_{\mathrm{CE}}$ was found in all traits. Moreover, $\mathrm{V}_{\mathrm{mE}}$ was significant for indole glucosinolate, linoleic acid (C18:2), eicosenoic acid (C20:1), and erucic acid (C22:1) contents. Except total SAE content in seed of oilseed rape, the maternal dominance $x$ environment interaction effect $\left(V_{D m E}\right)$ was significant for all those quality traits. 
Table 9. Estimation of genetic variance, covariance and GE interaction variance of quality traits in oilseed rape for oil, protein, glucosinolate, and fatty acids contents.

\begin{tabular}{|c|c|c|c|c|c|c|c|c|c|c|}
\hline \multirow{2}{*}{ Variance component } & \multirow{2}{*}{ Oil } & \multirow{2}{*}{ Protein } & \multicolumn{3}{|c|}{ GSL } & \multicolumn{5}{|c|}{ Fatty acids } \\
\hline & & & Indole & Aliphatic & Total & C18:1 & C18:2 & C18:3 & $\mathrm{C} 20: 1$ & $\mathrm{C} 22: 1$ \\
\hline \multicolumn{11}{|l|}{ Main genetic effects } \\
\hline $\mathrm{V}_{\mathrm{A}}$ & $10.25^{\star \star}$ & 0.00 & $1.08^{* *}$ & $16.81^{* *}$ & $11.91^{* *}$ & $201.30^{* *}$ & $6.87^{\star *}$ & 0.00 & $32.46^{\star *}$ & $46.48^{\star *}$ \\
\hline$V_{D}$ & 0.00 & $0.68^{* *}$ & 0.00 & 0.00 & 0.00 & 0.00 & 0.00 & 0.00 & $0.71^{* *}$ & $0.85^{* *}$ \\
\hline $\mathrm{V}_{\mathrm{C}}$ & $78.64^{* *}$ & $14.54^{* *}$ & $2.27^{* \star}$ & 0.00 & 0.00 & $234.30^{* *}$ & $24.73^{* *}$ & $7.24^{* *}$ & 0.00 & $5.07^{\star \star}$ \\
\hline $\mathrm{V}_{\mathrm{Am}}$ & $507.13^{* *}$ & $64.80^{* *}$ & $1.40^{* *}$ & $226.01^{* *}$ & $291.24^{* *}$ & $425.34^{* *}$ & 0.00 & 0.00 & 0.00 & 0.00 \\
\hline $\mathrm{V}_{\mathrm{Dm}}$ & $57.52^{* *}$ & $10.03^{* *}$ & $0.91^{* *}$ & $149.08^{* *}$ & $157.75^{\star \star}$ & $350.63^{* *}$ & $35.14^{* *}$ & $8.87^{* *}$ & $8.72^{* \star}$ & $10.38^{* *}$ \\
\hline $\mathrm{C}_{\mathrm{A} . \mathrm{Am}}$ & $157.53^{* *}$ & 0.00 & -0.20 & 0.00 & 11.28 & -56.67 & 0.00 & 0.00 & 0.00 & 0.00 \\
\hline $\mathrm{C}_{\mathrm{D} . \mathrm{Dm}}$ & 0.00 & -4.43 & 0.00 & 0.00 & 0.00 & 0.00 & 0.00 & 0.00 & 0.57 & -0.55 \\
\hline \multicolumn{11}{|c|}{ GE interaction effects } \\
\hline $\mathrm{V}_{\mathrm{AE}}$ & 0.00 & 0.00 & $1.25^{\star *}$ & $32.85^{\star *}$ & 0.00 & $57.08^{\star \star}$ & 0.00 & 0.00 & $3.23^{\star *}$ & $5.32^{* *}$ \\
\hline$V_{D E}$ & 0.00 & 0.00 & 0.00 & 0.00 & 0.00 & 0.00 & $8.66^{\star \star}$ & 0.00 & 0.00 & 0.00 \\
\hline $\mathrm{V}_{\mathrm{CE}}$ & $543.29^{* *}$ & $85.46^{* *}$ & $3.21^{* *}$ & $317.17^{\star \star}$ & $347.82^{* *}$ & $733.23^{* *}$ & $62.50^{* *}$ & $24.08^{* *}$ & $7.94^{\star *}$ & $10.62^{* *}$ \\
\hline$V_{\text {AmE }}$ & 0.00 & 0.00 & $2.63^{\star *}$ & 0.00 & 0.00 & 0.00 & $38.72^{* *}$ & 0.00 & $11.71^{* *}$ & $23.95^{\star *}$ \\
\hline$V_{D m E}$ & $184.37^{* *}$ & $29.21^{* *}$ & 0.00 & $120.40^{* *}$ & $138.85^{* *}$ & $308.29^{* *}$ & $23.87^{* *}$ & $6.39^{* *}$ & $6.43^{* *}$ & $8.16^{\star *}$ \\
\hline $\mathrm{C}_{\mathrm{AE} . \mathrm{AmE}}$ & 0.00 & 0.00 & -0.46 & 0.00 & 0.00 & 0.00 & 0.00 & 0.00 & 0.59 & -2.94 \\
\hline $\mathrm{C}_{\text {DE.DmE }}$ & 0.00 & 0.00 & 0.00 & 0.00 & 0.00 & 0.00 & -5.10 & 0.00 & 0.00 & 0.00 \\
\hline Ve & $173.74^{* *}$ & $21.50^{* *}$ & $1.83^{\star *}$ & $93.00^{* *}$ & $1070.93^{* *}$ & $352.07^{* *}$ & $19.50^{* *}$ & $6.84^{* *}$ & $3.43^{* *}$ & $4.62^{*}$ \\
\hline
\end{tabular}

$+,{ }^{*},{ }^{* *}=$ significantly different at $P=0.10,0.05$ and 0.01 , respectively. 
Table 10 . Estimation of genetic variance, covariance and GE interaction variance of quality traits in oilseed rape for sinapic acid esters.

\begin{tabular}{|c|c|c|c|c|}
\hline \multirow{2}{*}{ Variance component } & \multicolumn{4}{|c|}{ Sinapic acid esters } \\
\hline & $\operatorname{Sin} G I$ & Sinapine & Rest & Total \\
\hline \multicolumn{5}{|l|}{ Main genetic effects } \\
\hline $\mathrm{V}_{\mathrm{A}}$ & $0.25^{\star *}$ & 0.00 & $0.06^{* *}$ & 0.00 \\
\hline$V_{D}$ & $0.04^{* *}$ & $0.14^{* *}$ & $0.01^{* *}$ & $26.09^{\star *}$ \\
\hline $\mathrm{V}_{\mathrm{C}}$ & $3.40^{* *}$ & 0.00 & $0.67^{* *}$ & 0.00 \\
\hline$V_{A m}$ & $3.74^{* *}$ & $11.31^{* *}$ & $0.87^{* *}$ & $74.70^{\star *}$ \\
\hline $\mathrm{V}_{\mathrm{Dm}}$ & $0.56^{* *}$ & $0.61^{* *}$ & $0.11^{* *}$ & $26.26^{\star *}$ \\
\hline $\mathrm{C}_{\mathrm{A} . \mathrm{Am}}$ & 0.04 & 0.00 & 0.05 & 0.00 \\
\hline $\mathrm{C}_{\text {D.Dm }}$ & -0.26 & -4.39 & -0.03 & $6.56^{* \star}$ \\
\hline \multicolumn{5}{|l|}{ GE interaction effects } \\
\hline $\mathrm{V}_{\mathrm{AE}}$ & $0.33^{* *}$ & $1.37^{* *}$ & 0.13 & $122.92^{* *}$ \\
\hline$V_{D E}$ & 0.00 & 0.00 & 0.00 & $67.06^{* *}$ \\
\hline $\mathrm{V}_{\mathrm{CE}}$ & $1.79^{* *}$ & $11.20^{* *}$ & 0.59 & 0.00 \\
\hline$V_{\text {AmE }}$ & 0.00 & 0.00 & 0.00 & $104.39^{* *}$ \\
\hline$V_{\text {DmE }}$ & $1.28^{\star *}$ & $4.40^{* *}$ & $0.29^{* *}$ & 0.00 \\
\hline $\mathrm{C}_{\mathrm{AE} \cdot \mathrm{AmE}}$ & 0.00 & 0.00 & 0.00 & 3.17 \\
\hline $\mathrm{C}_{\text {DE.DME }}$ & 0.00 & 0.00 & 0.00 & 0.00 \\
\hline $\mathrm{Ve}$ & $0.86^{\star *}$ & $4.30^{* \star}$ & $0.20^{\star *}$ & $218.02^{* *}$ \\
\hline
\end{tabular}

$+,{ }^{*},{ }^{* *}=$ significantly different at $P=0.10,0.05$ and 0.01 , respectively 


\section{Relationship between increased seed oil content and high erucic acid (C22:1)}

The mean values of ten pollen parents and their $\mathrm{F}_{1} \mathrm{~s}$ for $\mathrm{C} 22: 1$ and oil contents are described in Table 11. The pollen parents 4 and 5 are high in C22:1 content. When the two zero-erucic females were pollinated by the high-erucic parents, the $F_{1}$ seeds showed both increased erucic acid and oil content.

When the mean values of those $\mathrm{F}_{1} \mathrm{~s}$ which produced from high $\mathrm{C} 22: 1$ pollen parents are compared with the mean of oil content, their $F_{1} s$ values in oil content show higher values than the mean.

When excluding the two high erucic pollinators from the analysis of variance (Table 12 ), the variance component due to male effects is considerably reduced, but is still significant. Therefore, the above results revealed a close relation between high erucic acid and increased oil content in seeds of winter oilseed rape.

Table 11. Comparison of mean values of pollen parents and $F_{1} s$ for erucic acid (C22:1) and oil content.

\begin{tabular}{lrrrrrrr}
\hline & \multicolumn{3}{c}{ C22:1(\%) } & \multicolumn{3}{c}{ Oil (\%) } \\
\cline { 2 - 8 } Pollen parents & \multicolumn{1}{c}{$\mathrm{P}$} & \multicolumn{1}{c}{$\mathrm{F}_{1}$} & $\mathrm{~F}_{1}{ }^{*}$ & $\mathrm{P}$ & $\mathrm{F}_{1}$ & $\mathrm{~F}_{1}{ }^{*}$ \\
\hline 1. DH-7 (Apex x Mohican) & 0.24 & 0.69 & 0.51 & 48.5 & 50.0 & 51.0 \\
2. H-48 & 0.03 & 0.42 & 0.65 & 45.3 & 49.6 & 50.1 \\
3. Express & 0.37 & 1.23 & 1.23 & 51.9 & 50.5 & 50.4 \\
4. DH-1 (Apex x Mohican) & 0.12 & 0.71 & 0.60 & 53.9 & 50.3 & 49.9 \\
5. DH-09 (Mansholts x Samourai) & $\mathbf{3 4 . 7 5}$ & $\mathbf{1 5 . 9 5}$ & $\mathbf{1 4 . 3 5}$ & $\mathbf{5 2 . 3}$ & $\mathbf{5 3 . 9}$ & $\mathbf{5 3 . 2}$ \\
6. H-10 & $\mathbf{2 8 . 9 9}$ & $\mathbf{8 . 8 4}$ & $\mathbf{7 . 2 7}$ & $\mathbf{4 7 . 1}$ & $\mathbf{5 1 . 7}$ & $\mathbf{5 0 . 8}$ \\
7. 1636-3 & 0.43 & 1.37 & 1.18 & 48.0 & 50.6 & 50.7 \\
8. 1684-2 & 0.28 & 0.86 & 0.95 & 47.2 & 49.1 & 49.5 \\
9. 5297 & 1.11 & 1.13 & 0.64 & 54.6 & 51.5 & 51.4 \\
10. Falcon & 0.16 & 0.88 & 0.47 & 50.3 & 48.6 & 49.1 \\
\hline Mean & & & & 49.9 & 50.6 & 50.6 \\
\hline
\end{tabular}

$\mathrm{P}=$ Pollen parents; $\mathrm{F}_{1}=(\mathrm{MS}$-Falcon $\times \mathrm{P}) ; \mathrm{F}_{1}{ }^{*}=($ MS-Express $\times \mathrm{P})$. 
Table 12. Comparison between mean squares $(\mathrm{MQ})$ and variance components of the analysis of variance for oil content of $F_{1} s$ with high $\mathrm{C}_{2} 2: 1$ pollen parents and without high $\mathrm{C} 22: 1$ pollen parents.

\begin{tabular}{|c|c|c|c|c|c|c|}
\hline \multirow{2}{*}{ Source } & \multicolumn{3}{|c|}{$\begin{array}{c}\mathrm{F}_{1} \mathrm{~s} \\
\text { (with high } \mathrm{C} 22: 1 \text { pollen parents) }\end{array}$} & \multicolumn{3}{|c|}{$\begin{array}{c}\mathrm{F}_{1} \mathrm{~s} \\
\text { (without high } \mathrm{C} 22: 1 \text { pollen parents) }\end{array}$} \\
\hline & DF & $M Q$ & Var. com & DF & $M Q$ & Var. com \\
\hline Male (M) & 9 & $20.4^{\star \star}$ & 1.34 & 7 & $7.90^{+}$ & 0.42 \\
\hline Female (F) & 1 & 0.0 & -0.35 & 1 & 1.48 & -0.51 \\
\hline Environment (E) & 2 & 19.8 & 0.26 & 2 & 25.41 & 0.62 \\
\hline$M \times F$ & 9 & 1.2 & 0.02 & 7 & 0.65 & 0.03 \\
\hline$M \times E$ & 18 & $4.4^{\star *}$ & 0.80 & 14 & $2.89^{* *}$ & 0.45 \\
\hline$F \times E$ & 2 & $21.3^{* *}$ & 1.01 & 2 & $26.11^{* *}$ & 1.56 \\
\hline$M \times F \times E$ & 18 & 1.0 & -0.07 & 14 & 0.45 & -0.33 \\
\hline
\end{tabular}

$+,{ }^{*},{ }^{* *}=$ significantly different at $P=0.10,0.05$, and 0.01 .

\section{Discussion}

Because of the importance of seed quality in uses, understanding the inheritance of seed quality traits in oilseed rape is important for plant breeders to develop cultivars. Because of the complicated genetic control on the seed quality traits, the understanding of its inheritance is still limited.

The results on fatty acid composition of the seed reported (Thomas and Kondra, 1973). Erucic acid (C22:1) content is conditioned by the genotype of the seed and not by that of the mother plant (Downey and Craig, 1964). Erucic acid (C22:1) and eicosenoic acid (C20:1) contents in rapeseed (B. napus and B. rapa) are controlled by the genotype of the developing embryo and not by the sporophyte (Dorrel and Downey, 1964). The reports of Ecke et al. (1995), and Lühs and Friedt (1995) showed that erucic acid (C22:1) content in Brassica napus is inherited by two genes which act in additive gene action. For the erucic acid content in B. rapa and $B$. oleracea up to $30 \%$ the alleles showed additive effect, while at higher concentration partial dominance was common (Jönsson, 1977).

Also this study showed that both erucic acid (C22:1) and eicosenoic acid (C20:1) contents are influenced by the pollen genotype with both additive and dominant seed effects, and dominant maternal effects. The additive effects of variance were greater 
than dominant effects, therefore early selection for $F_{2}$ seeds by NIRS is possible for these traits.

Pollen genotype additive effects were important for oleic acid (C18:1) and linoleic acid (C18:2). Moreover, cytoplasmic, maternal additive, and maternal dominance effects were also observed for oleic acid (C18:1) content. Therefore, early selection can be utilised in this trait, but the other effects should be considered. In linoleic acid (C18:2) content showed exclusively the maternal dominance. However, linolenic acid (C18:3) content was conditioned only by cytoplasmic and maternal dominant effects. Therefore, to improve the oleic acid (C18:1) content, selection of $F_{2}$ seeds with NIRS can be available up to a limit amount. The demand for reducing level of polyunsaturated fatty acids (PUFA) and the resulting increase in the level of the monounsaturated oleic acid (C18:1) are associated with a higher oxidative stability and reduced oxidation product in the oil without the need for extensive hydrogenation (Scarth and McVetty, 1999). The results were in agreement with Schierholt et al. (2001) who observed mainly additive seed effects for high oleic acid content, but cytoplasmic, maternal additive and dominance effects were also found in the current study.

The present study indicated that the oil content was also influenced by male pollen additive effects. Maternal additive effects were important to determine the oil content. Therefore, to improve the oil content both high oil female and high male pollen parents should be used in breeding programme. Moreover, the variance of additive effects of both seed and maternal female was greater than dominance variance, indicating that early selection for oil content is possible. Grami et al. (1977) showed that oil, protein and sum of oil and protein content were governed by additive gene action and dominance was not significant and epistasis was absent.

The result for protein content showed that this trait was significantly determined by the genotype of maternal plant while the influence of male pollen was not significant, and additive effects were more important than dominance effects in maternal genotype. The same result was also described in comparisons among self-and crossed pollinated seeds from two spring rape cultivars (Grami and Stefansson, 1977). The selection of high protein content for female parent is important for 
improvement of protein content. But environmental effect should be also considered in this improvement.

For glucosinolate (GSL) content the current study showed male pollen effects on indole glucosinolate content. The hydroxylation of glucobrassicin to 4-hydroxyglucobrassicin $(4 \mathrm{OH})$ occurs in the embryo (Herrmann, 1992). This is in agreement with positive male pollen effects in indole glucosinolate $(4 \mathrm{OH})$. Because of the aliphatic glucosinolate components are the main glucosinolate content, the positive correlation with pollen parents in the indole glucosinolate does not result in significant effects for the total glucosinolate content. Therefore, total glucosinolate in $F_{1} s$ did not show a significant correlation with their pollen parents. A study reported that glucosinolate content in $B$. juncea and $B$. napus is maternally controlled (Kondra and Stefansson, 1970). The present study showed significant additive seed effects for this trait, but maternal additive and dominant effects were more important. Therefore, early selection will not be very successful because of the maternal dominant effect found on its traits.

As to sinapic acid esters, not only maternal effects, but also pollen genotype additive and dominant effects determined sinapoylglucose (SinGI) and the rest of SAE contents. Both sinapine and total SAE also have pollen genotype influenced with dominant manner, and environmental effect influenced all traits. Wang et al., (1998) also found that environmental conditions influence sinapine levels.

The results of the current study indicated that there are pollen genotype effects on $\gamma$ tocopherol and $\alpha / \gamma$-tocopherol ratio. The effects of environment on genotype should be considered for those both $\alpha$-and $\gamma$-tocopherol contents but not for $\alpha$-tocopherol and total tocopherol.

The erucic acid (C22:1) is a long-chain component in fatty acids and the molecular weight is greater than for other fatty acids. Therefore, increased content of C22:1 may have an effect of increasing oil content. For C22:1 content it is already known that it is influenced by pollen genotype effects. As to oil content, it was expected that there is a pollen genotype effects on that trait, too. This hypothesis is supported by the observation, that there is a relationship between increased seed oil content and high C22:1 in oilseed rape. This relating result is in agreement with the observation, 
that two of the QTLs for oil content showed a close association in location to the two erucic acid genes, indicating a direct effect of the erucic acid genes on oil content (Ecke et al., 1995).

\section{Acknowledgements}

The financial support provided by the "Gesellschaft zur Förderung der privaten deutschen Pflanzenzüchtung (GFP)" and "Deutscher Akademischer Austauschdienst (DAAD)" is gratefully acknowledged. The authors thank KWS and Saatzucht Hadmersleben for performing field tests and Norddeutsche Pflanzenzucht (NPZ) for providing the male sterile lines. Sonja Yaman, Uwe Ammermann and Nicole Ritgen-Homayounfar are gratefully acknowledged for their technical assistance. Volker Marwede is gratefully acknowledged for helping in tocopherol analysis.

\section{References}

Diepenbrock, W., and F. Grosse. 1995. Rapeseed (Brassica napus L.). In: Diepenbrock, W., and H.C. Becker (eds): Physiological Potentials for Yield Improvement of Annual Oil and Protein Crops. Advances in Plant Breeding 17:21-53.

Dorrell, D.G., and R.K. Downey. 1964. The inheritance of erucic acid content in rapeseed (Brassica campestris). Canadian Journal of Plant Science 44:499504.

Downey, R.K., and B.M. Craig. 1964. Genetic control of fatty acid biosynthesis in rapeseed (Brassica napus L.). Journal of American Oil Chemistry Society 41:475-478.

Ecke, W., M. Uzunova, and K. Weißleder. 1995. Mapping the genome of rapeseed (Brassica napus L.). II. Localisation of genes controlling erucic acid synthesis and seed oil content. Theoretical and Applied Genetics 91:972-977.

Grami, B., and B.R. Stefansson. 1977. Paternal and maternal effects on protein and oil content in summer rape. Canadian Journal of Plant Science 57:945-949. 
Grami, B., R.J. Baker, and B.R. Stefansson. 1977. Genetics of protein and oil content in summer rape: Heritability, number of effective factors, and correlation. Canadian Journal of Plant Science 57:937-943.

Herrmann, M. 1992. Die Einlagerung von Indolglucosinolaten in den reifenden Rapssamen (Brassica napus). Doctoral Dissertation, Georg August Universität, Göttingen.

Jönsson, R. 1977. Erucic-acid heredity in rapeseed (Brassica napus L. and Brassica campestris L.). Hereditas 86:159-170.

Kondra, Z.P. and B.R. Stefansson. 1970. Inheritance of the major glucosinolates of rapeseed (B. napus) meal. Canadian Journal of Plant Science 50:643-647.

Lühs, W., and W. Friedt. 1995. Breeding high-erucic acid rapeseed by means of Brassica napus resynthesis. Proceedings of the $9^{\text {th }}$ International Rapeseed Congress, Cambridge, United Kingdom, 2:449-451.

Rosa, E.A.S. 1999. Chemical composition. In: G. Gomez-Campo (eds): Biology of Brassica Coenospcies, Elsevier, Amsterdam, pp.315-357.

Scarth, R., and P.M. McVetty. 1999. Designer oil canola - A review of new foodgrade Brassica oils with a focus on high oleic, low linolenic types. [CD-ROM]. In N. Wratten and P.A. Salisbury (eds): Proceedings of the $10^{\text {th }}$ International Rapeseed Congress, Canberra.

Schierholt, A., B. Rücker and H.C. Becker. 2001. Inheritance of high oleic acid mutations in winter oilseed rape (Brassica napus L.). Crop Science 41:14441449.

Spinks, E. A., K. Stones, and G.R. Fenwick. 1984. The quantitative analysis of glucosinolates in cruciferous vegetables, oilseeds and forage crops using high performance liquid chromatography. Fette Seifen Anstrichm 86:228-231.

Thies, W. 1971. Schnelle und einfache Analysen der Fettsäurezusammensetzung in einzelnen Raps-Kotyledon. Zeitschrift für Pflanzenzüchtung 65:181-202. 
Thies, W. 1988. Isolation of sinigrin and glucotropaeolin from cruciferous seeds. Fat Science Technology 90:311-314.

Thies, W. 1997. Entwicklung von Ausgangsmaterial mit erhöhten $\alpha$-oder $\gamma$ Tocopherolgehalten im Samenöl für die Körnerrapszüchtung. I. Quantitative Bestimmung der Tocopherole durch HPLC. Angewandte Botanik 71:62-67.

Thomas, P.M., and Z.P. Kondra. 1973. Maternal effects on the oleic, linoleic, and linolenic acid content of rapeseed oil. Canadian Journal of Plant Science 53:221-225.

Tillmann, P. 2004. www.vdlufa.de/nirs. Site last time visited 03.07.2004.

Utz, H.F. 1997. Plabstat-Ein Computerprogramm zur statistischen Analyse von pflanzenzüchterischen Experimenten. Version $2 \mathrm{~N}$. Institute für Pflanzenzüchtung, Saatgutforschung und Populationsgenetik, Universität Stuttgart-Hohenheim. (http:/www.uni-hohenheim.de/-ipspwww/soft.html)

Wang, S.X., B.D. Oomah, D.I. McGregor, and R.K. Downey. 1998. Genetic and seasonal variation in the sinapine content of seed from Brassica and Sinapis species. Canadian Journal of Plant Science 78:395-400.

Zhu, J. 1994. General genetic models and new analysis methods for quantitative traits. Journal of Zhejiang Agri University 20:551-559.

Zhu, J. 1996. Analysis methods for seed models with genotype $x$ environment interaction. (Chinese). Acta Genetica Sinica 23:56-68.

Zhu, J., and B.S. Weir. 1994. Analysis of cytoplasmic and maternal effects: A genetic model for diploid plant seeds and animals. Theoretical and Applied Genetics 89:153-159. 
Manuscript II 


\title{
Non-destructive analysis of oil, protein and glucosinolate content in single seeds of oilseed rape by NIRS
}

\begin{abstract}
Near-infrared reflectance spectroscopy (NIRS) is widely used as a fast and nondestructive method for the seed quality analysis in different crops, normally using about 3 grams of seeds. The availability of NIRS for the quality analysis of individual $F_{2}$ seeds derived from a segregating population could be important for a rapid progress in breeding for different quality traits. The main objective of the present study was to develop reliable NIRS calibration equations for the analysis of oil, protein and glucosinolate content of single $F_{2}$ seeds. A collection of seeds with a wide-range of oil, protein and glucosinolate content as well as glucosinolate composition was used for calibration development. A close correlation of $R^{2}=0.98$ was found between the oil content of the single seeds as determined by the gravimetric reference method and as predicted by NIRS. Equally good correlations between the results of the reference method and the NIRS predictions were found for protein $\left(R^{2}=0.99\right.$; Reference method: 'Dumas') and glucosinolate content $\left(R^{2}=\right.$ 0.97; Reference method: 'HPLC'). The coefficients of determination after crossvalidation $(1-\mathrm{VR})$ were $0.97,0.96$, and 0.87 for seed oil, protein, and total glucosinolate, respectively. Furthermore, useful correlations between NIRS and reference values were found for the aliphatic glucosinolate $R^{2}=0.96$, indole glucosinolates $R^{2}=0.91$, and the aromatic glucosinolates $R^{2}=0.82$. When the NIRS equation developed for the standard ring cup with 3 gram seeds was applied to NIRS spectra of the single seeds, the correlation between NIRS and reference values showed $R^{2}=0.79^{\star *}$ for oil content and $R^{2}=0.84^{* *}$ for protein content. It can be concluded that the three single seed calibration equations developed can be used to select among segregating $F_{2}$ seeds for oil, protein and glucosinolate content.
\end{abstract}




\section{Introduction}

Oilseed rape quality traits like oil, protein and glucosinolate contents as well as fatty acid composition can be modified by classical breeding and gene technological approaches. Near-infrared reflectance spectroscopy (NIRS) has been shown to be useful to routinely estimate these quality traits simultaneously and in a quick and non-destructive manner in 3 gram seed samples (Daun and Williams, 1995).

Until the mid-1990's, near-infrared spectroscopy was commonly used for measuring characteristics of biological materials which were only from ground or whole-grain bulk samples (Greenwood et al., 1999). However, attempts were also made to use NIRS to determine the quality of single seeds.

In oilseed rape, NIRS was used for non-destructive analysis of single seeds for different quality traits (Sato et al., 1998; Velasco et al., 1999; Velasco and Möllers, 2002). However, the possibilities for the analysis of total and individual glucosinolates in single seeds of oilseed rape by NIRS are still limited.

The knowledge about the inheritance of oil, protein, and glucosinolates content in oilseed rape is not very profound. For example, it is assumed that those seed quality traits are determined only by the maternal plant. Recent investigations indicated that the seed protein content can be down regulated (Kohno-Murase et al., 1994 and 1995) and the seed oil content can be increased (Zou et al., 1997) in oilseed rape by molecular gene transfer using constructs with a seed specific promoter. These results show that the seed quality can be also determined by the genotype of the growing embryo, and not by the genotype of the seed plant. In recent years, oilseed rape quality is of increasing interest for various food and non-food uses.

To fulfil all future requirements, improvement of the seed quality is one of the most important objectives in oilseed rape breeding (Becker et al., 1999). Therefore, adequate methods for measurement of seed quality play an important role for seed quality improvement in plant breeding.

The present experiments were undertaken to study the possibility of using NIRS to predict the oil, protein, total and individual glucosinolate content in single seeds of oilseed rape. Developed calibrations could be useful if seed quality traits are influenced by the genotype of the embryo; the $F_{2}$ seeds grown on $F_{1}$ plants already 
segregate and selection between individual seeds is possible like traditionally done for fatty acids by the half-seed method (Thies, 1971). Moreover, if seed specifically expressed mutants or transgenes affect one of these traits, selection could be performed among single seeds of segregating $F_{2}$ or first generation transgenic $T_{2}$ seed populations.

\section{Materials and Methods}

\section{Seed material}

Calibration equations for oil, protein, total and types of side chain (aliphatic, indole and aromatic) glucosinolates (GSLs) contents were developed for single seeds of oilseed rape. The samples for the calibration were selected from different years, locations, genotypes (resynthesized rapeseed, double haploid lines, $F_{1} s$ ) and including large ranges for specific quality traits. Healthy, round and normal weight ( 5.5-6.5 mg) seeds were used for development of the calibration equations. Before scanning the sample seeds, they were dried in oven at $65^{\circ} \mathrm{C}$ for $7 \mathrm{~h}$ and adjusted them at room temperature about 3h. For NIRS analyses, a special adapter was used for intact single seeds.

The adapter was made of $4 \mathrm{~mm}$ thick Teflon with $38 \mathrm{~mm}$ diameter and a $3 \mathrm{~mm}$ central hole (Figure $1 \mathrm{a}$ ). It was made at the Institute of Agronomy and Plant Breeding of the University of Göttingen, Germany. This adapter was inserted into the standard ring cup and the single seeds were put into the central hole (Figure 1b).

The seed was fixed with a small $5 \mathrm{~mm}$ long Teflon rod, which fit into the hole of the adapter from the back. Finally, the ring cup was closed with a disposable sample cup back. Then they were scanned by NIRS monochromator model 6500, and their spectra collected between $400-2500 \mathrm{~nm}$, registering the absorbance values $\log (1 / \mathrm{R})$ at $2 \mathrm{~nm}$ intervals for each sample. 


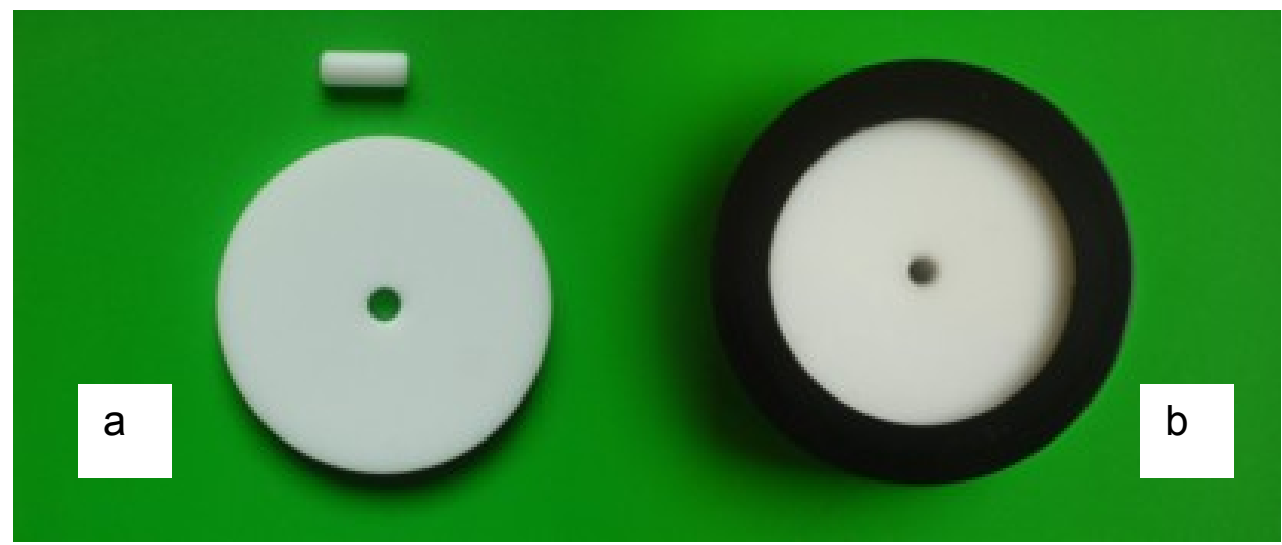

Figure 1. Special Teflon adapter with a central hole for fixing a single seed and a small Teflon rod (a), and special Teflon adapter in a standard ring cup with a single seed in the central hole (b).

\section{Analyses of the sample single seeds with reference methods}

After NIRS scanning, the seeds were analysed by reference methods: repeated extraction with a solution i-octan: i-propanol 9:1 for oil content ( $\%$ of seed weight), Dumas combustion for protein (\% of seed weight) and High-Performance Liquid Chromatography (HPLC) for quantitative determination of individual and total GSLs $(\mu \mathrm{mol} / \mathrm{g})$, respectively.

\section{i. Repeated extraction/gravimetric method for seed oil content}

Individual heavy-walled test tubes ca. $50 \mathrm{~mm} \times 6.5 \mathrm{~mm} \varnothing$ (No. 2775/0) were weighed exactly on a lab balance model 2004 MP (Sartorius, Göttingen, Germany) with a readability up to decimal five $(0.00001 \mathrm{~g})$. Each of sample single seeds were placed in previously-weighed test tubes and weighed exactly together. $100 \mu \mathrm{l}$ of iso-octon: iso-propanol (9:1) were added to the test tubes and the seeds were finely crushed with an stainless steel rod. The rest of seed powder on the steel rod was cleaned carefully with $100 \mu \mathrm{l}$ of iso-octon: iso-propanol (9:1) again, added $500 \mu \mathrm{l}$ of petrolether $\left(40^{\circ} \mathrm{C}\right.$ or $50-70^{\circ} \mathrm{C}$ boiling point, b.p.), and mixed on VORTEX mixer. After 10 min centrifugation, liquid-extract (supernatant) was pipetted carefully, added 500 $\mu$ of petrolether $\left(40^{\circ} \mathrm{C}\right.$ or $50-70^{\circ} \mathrm{C}$ b.p), mixed on VORTEX, centrifuged, and taken out the liquid-extraction. After the extraction process, the test tubes containing the defatted meal were dried at $30^{\circ} \mathrm{C}$ in the oven about $2 \mathrm{~h}$ and weighed. The drying and weighing procedures were done up to the weight was not changed. Approximately 3 
hours duration was enough for the solvent-evaporation in single seeds. The total seed oil content was expressed as percentage oil per gram seeds.

\section{ii. Dumas combustion for protein content}

Sample of 157 single seeds were weighed on a lab balance model M2P (Sartorius, Göttingen, Germany) with a readability of $0.001 \mathrm{mg}$, then each of them were sealed with small sheet of aluminium foil. After those procedure, they were analysed for nitrogen concentration by the Dumas combustion method with an automated $\mathrm{CN}$ analyser (varioEL, Elementar $\mathrm{GMbH}$, Hanau, Germany), and transformed the protein content to $\%$ in dry weight.

\section{iii. High-performance liquid chromatography (HPLC) for GSL content}

The individual ca. $50 \times 6.5 \mathrm{~mm} \varnothing$ (No. 2775/0) heavy-walled test tubes were weighed exactly on a lab balance model 2004 MP. Individual seeds were put into the weighed test tubes. First, $100 \mu \mathrm{l}$ of iso-octan : iso-propanol were added.

Next, they were weighed and dried in desiccator up to the weight was not changed. And then, they were heated in water bath at $70^{\circ} \mathrm{C}$ about $5 \mathrm{~min}$ and added $200 \mu \mathrm{l}$ of methanol $(\mathrm{MeOH})$, mixed on VORTEX mixer, and heated them in water bath again and added exactly $10 \mu \mathrm{l}$ internal standard solution (6 mmol glucotropaeolin (GTL)/ I water) which was prepared according to Thies (1988). After 10 min extraction, mixed on VORTEX two times, and added $300 \mu \mathrm{l}$ water. After $5 \mathrm{~min}$ centrifugation, the extract was moved on the top of a 100mg Sephadex DEAE-A-25 column (shortened Pasteur pipette), washed the columns three times with water, put $75 \mu \mathrm{l}$ purified sulfatase $\left(H 1^{*}\right.$, Helix pomatia sulfatase, purified to $\left.3.33^{*} \mathrm{mg} / \mathrm{m}\right)$ solution $\left(1^{*}: 2.5\right.$ water) in each column, and over night at $39^{\circ} \mathrm{C}$ in oven.

Elution of the desulfoglucosinolates was done by adding two times $500 \mu \mathrm{H}$ HPLC water/ column, captured the effluent fraction in each $3 \mathrm{ml}$ PS (Polystyrol) tube, and mixed on VORTEX. Finally, the solution from each sample tube was transferred into $1 \mathrm{ml}$ sample vials and analysed by HPLC. Glucosinolates were determined by the HPLC gradient method for desulfated GSLs as described by Kräling et al. (1990). The glucosinolate contents of each single seed were converted to $\mu \mathrm{mol} \mathrm{g}^{-1}$ dry weight. 


\section{Data analysis and development of the calibration equations}

Calibration equations were developed under WinISI II Project Manager v 1.02a, with spectral information from $400-2500 \mathrm{~nm}$ and using modified partial least squares (MPLS) regression and cross-validation technique.

The mathematical treatment for each constituent were $1,4,4,1$ for oil, 2,5,5,1 for protein and 3,6,6,1 for glucosinolate content, respectively. The first number is the derivative, the second number the gap, and third and fourth numbers are the smooth.

The content of aliphatic glucosinolates included progoitrin (PRO), glucoerucin (ERU), sinigrin (SIN), glucobrassicanapin (GBN), gluconapin (GNA), and gluconapoleiferin (GNL). The components of 4-hydroxyindol-3-ylmethyl glucosinolate $(4 \mathrm{OH})$, glucobrassicin (GBC), neoglucobrassicin (NEO) and 4-methoxyglucobrassicin (4ME) were combined for indole glucosinolate. Only gluconasturtiin (NAS) was the only aromatic glucosinolate. The sum of all glucosinolates were presented as total glucosinolate.

\section{Results}

\section{Statistical analysis of calibration equation for seed quality in single seeds}

Calibration equations for seed oil, protein, and total and types of glucosinolates were developed and evaluated through cross validation. The statistics of calibration showed $R^{2}=0.98$ for seed oil (Figure 2), $R^{2}=0.99$ for seed protein and $R^{2}=0.97$ for total glucosinolate content between reference methods and NIRS values (Table 1). Furthermore, the coefficients of determination for aliphatic, indole and aromatic glucosinolates were found to be $R^{2}=0.96, R^{2}=0.91$ and $R^{2}=0.82$, respectively.

Wide ranges for contents of oil (26.2-61.1\%), protein (14.7-32.1\%), total GSLs (0.6$118.9 \mu \mathrm{mol} / \mathrm{g})$, aliphatic GSLs $(0.6-86.0 \mu \mathrm{mol} / \mathrm{g})$, indole GSLs $(0.2-12.2 \mu \mathrm{mol} / \mathrm{g})$, and aromatic GSL (0.3-2.1 $\mu \mathrm{mol} / \mathrm{g})$ in single seeds were performed in the developed calibration equations. High coefficients of determination in cross-validation were found in oil (0.97), protein (0.96), and total GSLs (0.87) and modearte results were found in aliphatic GSLs and indole GSLs (0.83 and 0.77 ). The results indicated that estimation of oil, protein, and glucosinolates (excluded aromatic glucosinolate) contents in single intact seeds of rapeseed oil is available by using NIRS method. A reliable selection for those traits in segregating population in $F_{2}$ seeds can be 
selected by using NIRS scanning method. The calibration equations developed in the study for oil, protein, and total GSLs were used for selection in single seeds of oilseed rape.

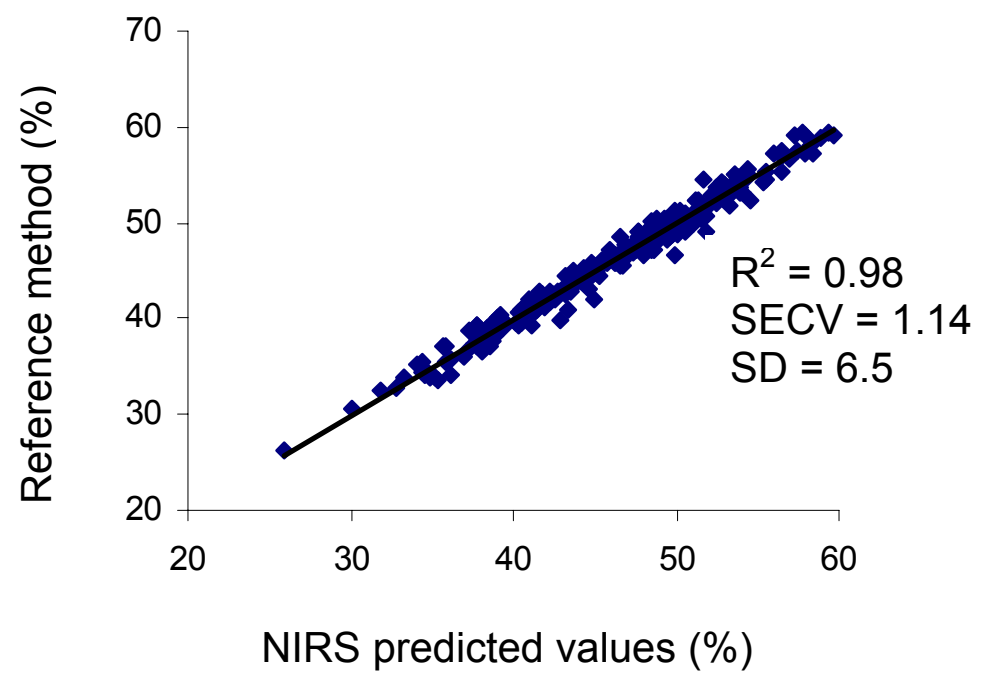

Figure 2. Correlation between NIRS predicted oil content (\%) and reference method in a set of 206 single seeds of oilseed rape. $\mathrm{R}^{2}=$ coefficient of determination, SECV = standard error of cross validation, SD= standard deviation of the samples.

Table 1. NIRS statistics of the calibrations for the contents of oil, protein and glucosinolates (GSLs) in single seeds.

\begin{tabular}{|c|c|c|c|c|c|c|c|c|}
\hline \multirow[b]{2}{*}{ Seed quality traits } & \multirow[b]{2}{*}{$n$} & \multicolumn{4}{|c|}{ Calibration } & \multirow[b]{2}{*}{$\mathrm{RSQ}$} & \multicolumn{2}{|c|}{ Cross-validation } \\
\hline & & Mean & Range & SD & SEC & & SECV & 1-VR \\
\hline Oil content & 206 & 45.7 & $26.2-61.1$ & 6.5 & 0.98 & 0.98 & 1.14 & 0.97 \\
\hline Protein content & 157 & 20.9 & $14.7-32.1$ & 3.6 & 0.38 & 0.99 & 0.74 & 0.96 \\
\hline \multicolumn{9}{|l|}{ Glucosinolates } \\
\hline -Aliphatic GSL & 109 & 25.7 & $0.6-86.0$ & 2.2 & 4.27 & 0.96 & 9.17 & 0.83 \\
\hline -Indole GSL & 87 & 4.3 & $0.2-12.2$ & 3.5 & 1.03 & 0.91 & 1.68 & 0.77 \\
\hline -Aromatic GSL & 35 & 0.9 & $0.3-2.1$ & 0.5 & 0.20 & 0.82 & 0.42 & 0.23 \\
\hline -Total GSL & 111 & 32.5 & $0.6-118.9$ & 27.4 & 4.92 & 0.97 & 10.04 & 0.87 \\
\hline
\end{tabular}

$\mathrm{SD}=$ standard deviation, $\mathrm{SEC}=$ standard error of calibration, $\mathrm{RSQ}=$ coefficient of determination, SECV $=$ standard error of cross-validation, $1-V R=R S Q$ after cross validation . 
Correlation between the values of reference methods in single seeds and 3 grams (g) standard

The spectra collected from single seeds were also used to predict the oil, protein and glucosinolate content applying an NIRS-calibration that was developed for a standard ring cup and approximately $3 \mathrm{~g}$ seeds (Raps2001.eqa, Tillmann, 2004). When the values from NIRS are compared with references values of oil, protein and glucosinolate, high positive correlations were found for oil content $\left(R^{2}=0.79^{* *}\right)$ (Figure 3). The correlation between NIRS (3 g standard) and reference method for the contents of protein and glucosinolate were also significant $\left(R^{2}=0.84^{\star *}\right.$ and $R^{2}=$ $\left.0.54^{* *}\right)$.

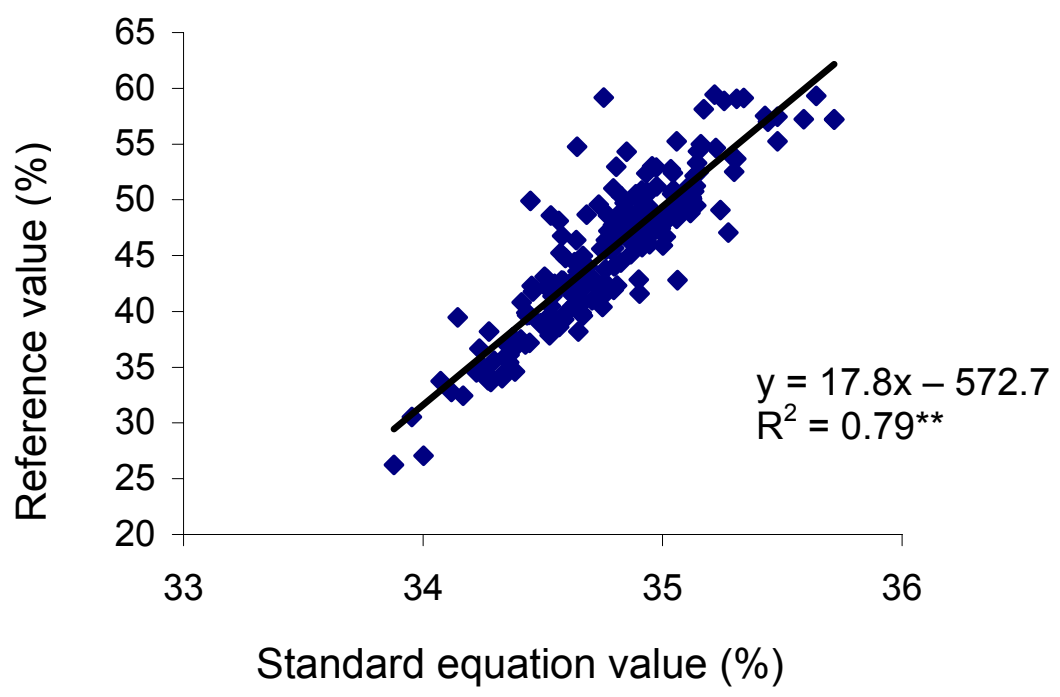

Figure 3. Correlation between oil content (\%) values by using the standard equation and reference method in single intact seeds.

\section{Discussion}

The 4-hydroxyindol-3-ylmethyl glucosinolate content, which constitutes approximately $75 \%$ of the residual glucosinolates in canola seed, remained unchanged (Slominski and Campbelle, 1987). However, there is some discussion about further lowering the glucosinolate content in oilseed rape. Further lowering of the glucosinolates will also require the reduction of the indole GSLs content in oilseed rape. Apart from the glucosinolates, the increase of oil content in seed of oilseed rape is a major interest of plant breeders and an increase of the protein content is also needed to feeding purposed. Accurate laboratory methods for determining the seed quality are lengthy, 
laborious and relatively hazardous. Therefore, the accuracy and reliability of NIRS techniques in estimation of seed quality in single seed are required.

The results obtained from this study show that good calibrations for the determination of oil and protein content when they were compared with reliable calibration equations which were developed for seed oil content $\left(r=0.94 ; R^{2}=0.90\right)$ by Velasco et al., (1999) and for protein content $\left(R^{2}=0.96\right)$ Velasco and Möllers (2002) in intact single seeds of oilseed rape.

The calibration for the determination of total glucosinolate content in intact single seeds gave also quite good results $\left(R^{2}=0.97\right)$ when it was compared with $300 \mathrm{mg}$ intact seeds $\left(R^{2}=0.99\right.$ and $\left.R^{2}=0.98\right)$ reported by Velasco and Becker (1998), and Velasco et al., (1999) in Brassica spp. and $\left(R^{2}=0.99\right)$ by De Haro et al., (1999) in Brassica juncea intact single seeds. They also reported for individual glucosinolates PRO, SIN and GNA in Brassica spp., and SIN and GLA in Brassica juncea. The combination of the individual side chain GSLs (aliphatic, indole and aromatic GSLs) were not reported.

Even, if the relationship between reference value was high for some components, the inhomogeneous sample set resulted in a poor coefficient of determination after crossvalidations only in aromatic glucosinolate. The seed sample number should be further increased to obtain an improved calibration. Because of including a wide range of glucosinolate content and their cultivars in development of calibration equation, some types of glucosinolate were not performed in all of the individual seeds. This probably has been caused by a small number sample and some individual glucosinolates were lacking completely in some seeds. Therefore, calibration equation was calculated automatically with the seeds which performed those types of glucosinolates. Some reference values which showed the outlier were also deleted by software of NIRS. Therefore, the individual types of side chain glucosinolates (aliphatic, indole and aromatic GSLs) showed lower seed amount than their total glucosinolate and the different seed amount were performed in the calibration equation for three types of glucosinolates.

Therefore, the wide ranges among the calibration equation indicated that the calibration can be useful in the selection of high and low contents in those seed 
quality traits. It indicates that the developed calibrations can be used to select among $F_{2}$ single seeds and also to identify single seeds of oilseed rape with these three compounds.

If there is variation in seed quality among $F_{2}$ seeds that has a sufficiently high heritability, single seed NIRS can be applied to select individual $F_{2}$-seeds of the desired quality. Generally, a good agreement between the reference data and NIRS predicted values for oil and protein, and aliphatic glucosinolates, indole glucosinolate, and total glucosinolate content in single intact seeds was found. When they are compared with the standard calibration for $3 \mathrm{~g}$ seeds, results of the studies show that single seed NIRS calibrations for oil and protein content are more reliable for measuring those quality traits in segregating $F_{2}$ or first generation transgenic $T_{2}$ seed population. More samples from different environments, genotypes generations and years should be included to improve the calibrations for the contents of the individual glucosinolates in single seeds.

Plant improvement depends on the ability to evaluate large numbers of individuals. There are the possibility of using NIRS analysis of oil, protein and glucosinolates in segregating seeds of $\mathrm{F}_{2}$ population of classical oilseed material and molecular transgenic oilseed rape material. The prediction of seed quality by NIRS is rapid and inexpensive, accurate enough and non-destructive to make the required separations among genetic segregates. Therefore, the developed calibrations can be used to estimate the genetic control of pollen genotype effects on the seed quality in winter oilseed rape.

\section{Acknowledgements}

The financial support provided by the "Gesellschaft zur Förderung der privaten deutschen Pflanzenzüchtung (GFP) and 'Deutscher Akademischer Austauschdienst (DAAD)" is gratefully acknowledged. Sonja Yaman, Nicole Ritgen-Homayounfar, Uwe Ammermann, Hans-Otto Heise and Gabi Kolle are gratefully acknowledged for their technical assistance. Thomas Zum Felde and Nurtjahjo Dwi Sasongko are gratetfully acknowledged for helping in development of the calibration equations. 


\section{References}

Becker, H.C., H. Löptien, and G. Röbbelen. 1999. Breeding: An overview. In: GòmezCampo, C. (eds): Biology of Brassica Coenospecies. Elsevier, Amsterdam, pp.413-460.

Daun, J.K., and P.C. Williams. 1995. Use of NIR spectroscopy to determine quality factors in harvest surveys of canola. IN: Groupe Consultatif International de Recherche sur le Colza (eds): Proceedings of the $9^{\text {th }}$ International Rapeseed Congress, Cambridge, Henry Ling, Dorchester, Uinted Kingdoms, pp.864-866.

De Haro, A., R. Font, M. Del Río, and J.M. Fernández-Martínez. 1999. Using NIRS for determining glucosinolate content in Brassica juncea seed [CD-ROM]. Proceedings of the $10^{\text {th }}$ International Rapeseed Congress. Canberra, Australia.

Greenwood, C.F., J.A. Allen, A.S. Leong, T.N. Pallot, T.M. Golder, and T. Golebiowski. 1999. An investigation of the stability of NIRS calibrations for the analysis of oil content in whole seed canola [CD-ROM]. Proceedings of the $10^{\text {th }}$ International Rapeseed Congress. Canberra, Australia.

Kohno-Murase, J., M. Murase, H. Ichikawa and J. Imamura. 1994. Effects of an antisense napin gene on striage compounds in tansgenic Brassica napus seeds. Plant Molecular Biology 26:1115-1124.

Kohno-Murase, J., M. Murase, H. Ichikawa, and J. Imamura. 1995. Improvement in the quality of seed storage protein by transformation of Brassica napus with an antisense for cruciferin. Theoretical and Applied Genetics 91:627-631.

Kräling, K., G. Röbbelen, W. Thies, M. Herrmann, and M.R. Ahmadi. 1990. Variation of seed glucosinolates in lines of Brassica napus. Plant Breeding 105:33-39.

Sato, T., I. Uezono, T. Morishita, and T. Tetsuka. 1998. Nondestructive estimation of fatty acid composition in seeds of Brassica napus L. by near-infrared spectroscopy. Journal of American Oil Chemistry Society 75:1877-1881.

Slominsky, B.A., and L.D. Campbelle. 1987. Gas chromatographic determination of indole glucosinolates are examination. Journal of the Science of Food and Agriculture 40:131-143. 
Thies, W. 1971. Schnelle und einfache Analysen der Fettsäurezusammen-Setzung in einzelnen Raps-Kotyledon. Zeitschrift für Pflanzenzüchtung 65:181-202.

Thies, W. 1988. Isolation of sinigrin and glucotropaeolin from cruciferous seeds. Fat Science Technology 90:311-414.

Tillmann, P. 2004. www.vdlufa.de/nirs. Site last time visited 03.07.2004.

Velasco, L., and C. Möllers. 2002. Nondestructive assessment of protein content in single seeds of rapeseed (Brassica napus L.) by near-infrared reflectance spectroscopy. Euphytica 123:89-93.

Velasco, L., and H.C. Becker. 1998. Analysis of total glucosinolate content and individual glucosinolates in Brassica spp. by near-infrared reflectance spectroscopy. Plant Breeding 117:97-102.

Velasco, L., C. Möllers, and H.C. Becker. 1999. Analysis of individual glucosinolates in Brassica spp. by near-infrared reflectance spectroscopy [CD-ROM]. Proceedings of the $10^{\text {th }}$ International Rapeseed Congress. Canberra, Australia.

Velasco, L., C. Möllers, and H.C. Becker, 1999. Estimation of seed weight, oil content and fatty acid composition in intact single seeds of rapeseed (Brassica napus L.) by near infrared reflectance spectroscopy. Euphytica 106:79-85.

Zou, J., V. Katavic, E.M. Giblin, D.L. Barton, S.L. MacKenzie, W.A. Keller, X. Hu, and D.C. Taylor. 1997. Modification of seed oil content and acyl composition in the Brassicaceae by expression of a yeast $s n-2$ acyltransferase gene. Plant cell 9:909-923. 
Manuscript III 


\section{Selection for seed quality of individual $F_{2}$ seeds in winter oilseed} rape

\section{Abstract}

If seed quality is determined by the embryo, the $F_{2}$ seeds grown on an $F_{1}$ plant already segregate and selection among individual seeds is possible. The objectives of this study are to determine the influence of pollen genotype on the seed quality traits oil, protein and glucosinolate contents and to analyse whether it is possible to select among segregating $F_{2}$ single seeds by NIRS. Two lines with low oil and high glucosinolate (GSL) contents and a line with low oil and low glucosinolate contents were crossed as pollen parents with a male sterile (MS) female (Express). A "double-low" (Capitol) cultivar as pollen parent and a "double-high " (DHMansholts) line as female were also crossed. Because of the close relation between near-infrared reflectance spectroscopy (NIRS) and reference values found for oil, protein and glucosinolate content for single seeds, individual $F_{2}$ seeds from those four different crosses were selected for high and low levels of protein, and glucosinolate (GSL) contents by NIRS. The selected bulks with high and low levels of protein and glucosinolate (GSL), respectively, were sown with two replications at three locations (Göttingen, Einbeck, Teendorf) in Northern Germany in the season 2002/2003. The $F_{3}$ seeds on $F_{2}$ plants were harvested separately from five selfpollinated plants (SP) and open-pollinated plants (OP) in each plot. Oil, protein, and GSL content of $F_{3}$ seeds and their parental lines were analysed by NIRS. Results showed that the OP were higher in oil content and lower in protein and GSL content than SP. The thousand seeds weight showed no difference between self and openpollinated plants. Moreover, significant difference between the selected low and high content levels in oil $(P=0.10)$, protein $(P=0.01)$, and glucosinolate $(P=0.10)$ among $\mathrm{F}_{2}$ seeds were observed by NIRS. The results indicated that there are pollen influences in seed quality traits for oil, protein, and GSL content in winter oilseed rape. Therefore it is possible to select for seed quality already by analysing single seeds of segregating $F_{2}$ populations. 


\section{Introduction}

Seed oil of plants belonging to the genus Brassica has received attention for their increasing role in supplying the world's need for food and industrial oils. "Doublelow" or "canola" oilseed rape is now second only to soybean as the most important source of oilseeds in the world. A further increase of the seed quality of oilseed rape is nevertheless of great interest. To develop more efficient selection methods a better understanding of the inheritance of seed quality would be very helpful.

Seeds of Brassica species consist of embryo, the endosperm and testa or seed coat (Diepenbrock and Grosse, 1995). The embryonic axis is occupied essentially by the hypocotyl and is nearly completely covered by cotyledons. In mature seed a rather small endosperm remains as a well-formed aleurone layer which is closely connected with the seed coat.

The breeding aims are to increase oil content and reduce glucosinolate content in order to improve meal quality as a protein-rich animal foodstuff. If seed quality is determined by the embryo, the $F_{2}$ seeds grown on an $F_{1}$ plant already segregate and selection between individual seeds is possible like traditionally done for fatty acids by the half-seed method. For a non-destructive analysis of oil content and fatty acid composition of individual seeds, the near-infrared reflectance spectroscopy (NIRS) has successfully been applied (Velasco et al., 1999).

The objectives of this study are to determine the pollen effects on oil, protein and glucosinolate contents by selecting segregating $F_{2}$ seeds and measuring the response to selection in multilocational field trials.

\section{Materials and Methods}

\section{Materials}

The materials are described in Table 1. Six parental lines with different levels of oil, protein and glucosinolate (GSL) content were used to produce four different crosses which were the crossing of the parental lines (no.2, 3 and 4) as pollen parents and the male sterile female line (no.1), and the cross of the parental line (no.5) as pollen parent and the parental line (no.6) as female parent. 
Table 1. Parental materials and their quality characteristics traits.

\begin{tabular}{llccc}
\hline No. & Parents & Oil $(\%)$ & Protein $(\%)$ & Glucosinolate $(\mu \mathrm{mol} / \mathrm{g})$ \\
\hline 1 & Express & 46.3 & 24.7 & 19.4 \\
2 & L-239 & 44.2 & 25.2 & 18.6 \\
3 & H-48 & 40.9 & 26.6 & 54.3 \\
4 & H-111/2 & 40.5 & 27.6 & 75.0 \\
5 & Mansholts & 46.4 & 27.4 & 66.9 \\
6 & Capitol & 45.1 & 23.9 & 18.3 \\
\hline
\end{tabular}

The male sterile (MS) female Express, was crossed with other three male pollen parent lines, and a "double-high" $(+,+)$ 'Manholts' [double haploid, (DH)] female was crossed with a "double-low" $(0,0)$ 'Capitol' male parental line. The six parental lines were grown and crossed in the green house in the season 2000/2001.

The $F_{1}$ seeds were grown in the field and 5 plants per $F_{1}$ cross were bagged for getting $F_{2}$ seeds at Reinshof, Göttingen in 2001.

\section{Analysing and selection among $F_{2}$ seeds}

After the calibration equations for single seeds were developed (Hom et al., 2003), they were used to predict protein and glucosinolate (GSL) content of individual $F_{2}$ seeds in each of the crosses. Five individual $F_{1}$ plants from each cross were analysed with $200 \mathrm{~F}_{2}$ seeds each. Based on these results a selection experiment was initiated.

The principle is illustrated in Figure 1 and Figure 2 for the seeds of one $F_{1}$ plant. In total $200 \mathrm{~F}_{2}$ seeds of this plant from the cross (low GSL $\mathrm{x}$ high GSL) were analysed for glucosinolate content first, and the 40 seeds with lowest and the highest glucosinolate content, respectively, were selected (Figure 1). The remaining 120 seeds were then analysed for protein content, and again the 40 seeds with lowest and highest protein content, respectively, were selected (Figure 2). The aim was to select for oil content, but when the experiment was started, no reliable NIRS calibration for oil content was available. Therefore, selection was performed for protein content instead, because in segregating populations, oil and protein content generally show a close negative correlation (Grami et al., 1977). Therefore, there were four groups (low protein, high protein, low GSL, high GSL) for each cross. 


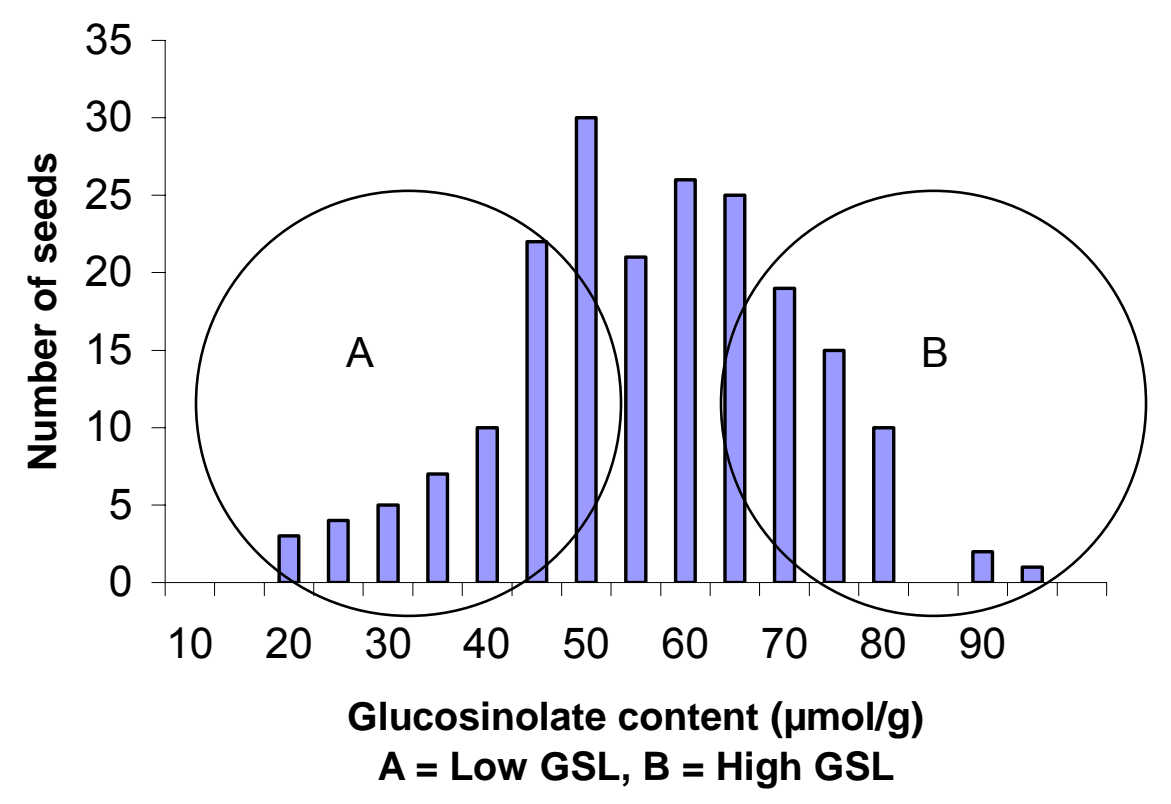

Figure 1. The distribution of glucosinolates content among 200 single seeds/plant and selected area for low and high glucosinolate $(\mu \mathrm{mol} / \mathrm{g})$.

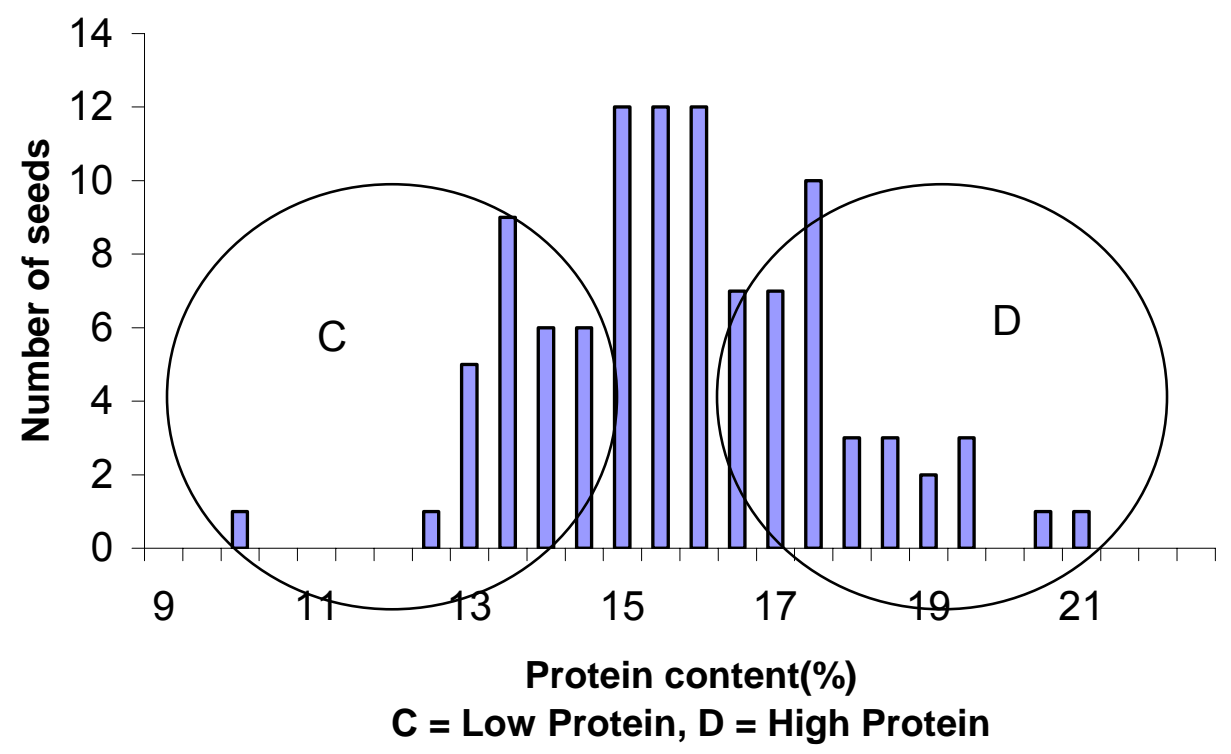

Figure 2. The distribution of protein content among 120 single seeds and number of selected seeds for low and high protein content (\%). 


\section{Experimental design and harvesting}

The selected $F_{2}$ seeds from $F_{1}$ plants were sown in a field trial to test the efficiency of the selection for seed quality traits. The selected plant materials high or low in protein or glucosinolate content, respectively, were evaluated in the season 2002/2003 in a randomized complete block design ( $R C B$ ) with a factorial treatment arrangement (4 types of selections $\times 4$ crosses) with two replications grown at each of three locations (Göttingen, Einbeck, Teendorf) in Germany.

The parental lines were also included in the experiment. They were drilled in plots with normal plant density of six rows $2.5 \mathrm{~m}$ long with rows $0.33 \mathrm{~m}$ apart and $0.1 \mathrm{~m}$ within rows. Five inflorescences per plot for SP treatment were covered with plastic bags to prevent pollen contamination. After fertilization, the plastic bags were removed to allow normal photosynthesis. When the siliques turned to brown colour the main stem and the first branch of the inflorescence were harvested. The five plants from each of the two pollination treatments and parental lines were handharvested from each plot. The experiment was planted in August 2002 and harvested in July 2003. Both self pollinated (SP) and open pollinated (OP) plants were harvested.

\section{Analysing the seed quality traits}

A bulk seed sample was collected from each plant and dried in oven about $7 \mathrm{hr}$ at $65^{\circ} \mathrm{C}$ for adjusting the moisture content and analysed for oil, protein and glucosinolate (GSL) content in oilseed rape by near-infrared reflectance spectroscopy (NIRS) using the Raps2001.eqa. (Tillmann, 2004).

The mean values of seed quality in parental lines with self-pollinated plants were compared with open-pollinated plants. The mean values in low and high contents of seed quality from four crosses in self-pollinated plants (SP) seed were compared with the mean values from open-pollinated plant (OP) seed at three locations. The seed samples from the self-pollinated plants and open-pollinated plants were then weighted for thousand seed weight with three replications of hundred seeds each and multiplied with 3.33 . 
Data for oil, protein and glucosinolate (GSL) content were analysed by the analysis of variance (ANOVA) procedure of PLABSTAT (Utz, version 2N, 1997). In all analyses the model treated location, replication, and plant as random effects. The other treatments were considered as fixed effects. Only crosses which were expected to segregate for quality were included in the analyses, therefore the data of selfpollinated $\mathrm{F}_{3}$ seed from three crosses (MS-Express $x$ L-239, MS-Express $\times \mathrm{H}-48$, MSExpress $\times \mathrm{H}-111 / 2$ ) were analysed for oil and protein contents, and the data of selfpollinated $\mathrm{F}_{3}$ seed from the crosses (MS-Express $\times \mathrm{H}-48$, MS-Express $\times \mathrm{H}-111 / 2$ and Mansholts $\times$ Capitol) were analysed for glucosinolate (GSL) content.

\section{Results}

\section{Mean values of seed quality in two different pollination systems}

Results of the mean values for parental lines in self-pollinated (SP) and openpollinated (OP) plants for oil, protein, and glucosinolate (GSL) from three locations are presented in Table 2. It indicates that except for Express parental line, the mean values of five parental lines in open-pollinated plants showed higher oil content than self-pollinated plants. In protein content, all the self-pollinated parental lines showed higher content than open-pollinated plants.

Among six parental lines, the three parents with high glucosinolate content showed lower glucosinolate content in open-pollinated plants than in self-pollinated plants. On the other hand, the three parents with low glucosinolate content showed higher glucosinolate content in open-pollinated plants than in self-pollinated plants.

The comparison between the mean values of all parental lines from self-pollinated plants and open-pollinated plants in oil, protein, and glucosinolate content at three locations are presented in Table 3. The mean values for open-pollinated plants showed higher oil content than self-pollinated plants. Protein and glucosinolate showed lower contents in open-pollinated plants than in self-pollinated plants at all three locations. 
Table 2. Mean values of parental lines in two different pollinations.

\begin{tabular}{llcccccc}
\hline \multirow{2}{*}{ No. } & \multirow{2}{*}{ Genotype } & \multicolumn{2}{c}{ Oil $(\%)$} & \multicolumn{2}{c}{ Protein $(\%)$} & \multicolumn{2}{c}{ Glucosinolate $(\mu \mathrm{mol} / \mathrm{g})$} \\
\cline { 2 - 7 } & & SP & OP & SP & OP & SP & OP \\
\hline 1 & Express & 46.3 & 45.8 & 24.7 & 24.4 & 19.4 & 26.2 \\
2 & L-239 & 44.2 & 45.7 & 25.2 & 24.2 & 18.6 & 21.1 \\
3 & H-48 & 40.9 & 42.0 & 26.6 & 25.7 & 54.3 & 40.5 \\
4 & H-111/2 & 40.5 & 43.1 & 27.6 & 25.4 & 75.0 & 67.8 \\
5 & Mansholts & 46.4 & 47.6 & 27.4 & 24.7 & 66.9 & 59.7 \\
6 & Capitol & 45.1 & 47.7 & 23.9 & 22.0 & 18.3 & 24.3 \\
\hline
\end{tabular}

Comparison between self and opened-pollinated plants for oil content showed higher oil content in open-pollinated plants at three locations (Table 4). When comparing the two pollination systems, the lower contents for protein and glucosinolate were found in open-pollinated plants at three locations.

\section{Comparison of the mean values of seed quality between parental lines and $F_{3}$ seed in self-pollinated plant}

The mean values of oil, protein, and glucosinolate content in parental lines and $F_{3}$ seed from the self-pollinated and open pollinated plants were compared (Table 3 and 4). There were differences in mean values in several seed quality traits.

Table 3. Mean values of parental seeds quality in two different pollination systems at three locations.

\begin{tabular}{lcccccc}
\hline & \multicolumn{2}{c}{ Oil (\%) } & \multicolumn{2}{c}{ Protein $(\%)$} & \multicolumn{2}{c}{ Glucosinolate $(\mu \mathrm{mol} / \mathrm{g})$} \\
\cline { 2 - 7 } Location & SP & OP & SP & OP & SP & OP \\
\hline Göttingen & 44.2 & 47.5 & 24.7 & 22.1 & 43.8 & 40.8 \\
Einbeck & 44.0 & 45.6 & 26.1 & 24.2 & 38.5 & 32.7 \\
Teendorf & 43.6 & 45.2 & 26.8 & 25.3 & 45.2 & 42.3 \\
\hline
\end{tabular}


Table 4. Mean values of $\mathrm{F}_{3}$ seeds quality in two different pollination systems at three locations.

\begin{tabular}{lcccccc}
\hline \multirow{2}{*}{ Location } & \multicolumn{2}{c}{ Oil $(\%)$} & \multicolumn{2}{c}{ Protein $(\%)$} & \multicolumn{2}{c}{ Glucosinolate $(\mu \mathrm{mol} / \mathrm{g})$} \\
\cline { 2 - 7 } & $\mathrm{SP}$ & OP & SP & OP & SP & OP \\
\hline Göttingen & 44.8 & 47.6 & 24.2 & 22.2 & 52.2 & 49.2 \\
Einbeck & 44.6 & 45.5 & 25.1 & 24.4 & 45.3 & 42.3 \\
Teendorf & 44.4 & 45.2 & 25.8 & 24.6 & 52.0 & 41.2 \\
\hline
\end{tabular}

\section{Analyses of variance for seed quality traits}

When the self-pollinated $F_{3}$ seeds from $F_{2}$ plants were analysed for seed quality traits, the combined analysis for the three locations showed significant effects among crosses and selection treatments for oil content. A significant effect of selection for oil content and highly significant effects among selections for protein content were found. Furthermore, there were significant effects for selection for glucosinolate (GSL) (Table 5).

The mean values of $\mathrm{F}_{3}$ seed from the selected bulks: high oil, low oil, high glucosinolate and low glucosinolate from three locations indicated the good response to the selected bulk (Table 6). The mean values of protein was negatively correlated with the oil content and glucosinolate content and positively correlated with oil content. No clear relationship was found between erucic acid and oil content.

Table 5. Mean square (MQ) and variance components of $F_{3}$ seed quality from single seed selection at three locations.

\begin{tabular}{lccccccc}
\hline & & \multicolumn{2}{c}{ Oil $(\%)$} & \multicolumn{2}{c}{ Protein $(\%)$} & \multicolumn{2}{c}{ Glucosinolate $(\mu \mathrm{mol} / \mathrm{g})$} \\
\cline { 3 - 8 } Source & DF & MQ & Var. com & MQ & Var. com & MQ & Var. com \\
\hline Location & 2 & 4.88 & -0.065 & $29.37^{+}$ & 0.413 & 1811.46 & 20.91 \\
Cross & 2 & $19.14^{+}$ & 0.264 & 13.91 & 0.093 & 962.41 & 4.64 \\
Selection & 1 & $39.50^{+}$ & 0.393 & $47.22^{* *}$ & 0.524 & $455.92^{+}$ & 4.67 \\
Cx S & 4 & 1.37 & -0.097 & 0.55 & -0.205 & 290.90 & -2.23 \\
Lx C & 4 & 3.31 & -0.727 & 8.32 & 0.034 & 683.74 & 15.81 \\
Lx S & 2 & 4.10 & -0.458 & 0.08 & -0.252 & 35.70 & -11.06 \\
\hline
\end{tabular}

,$+{ }^{*}{ }^{* *}=$ significantly different at $P=0.1,0.05$, and 0.01 , respectively 
Table 6. Mean values of $F_{3}$ seed quality from four crosses in three locations.

\begin{tabular}{lcccc}
\hline Selected bulks & Oil (\%) & Protein $(\%)$ & Glucosinolate $(\mu \mathrm{mol} / \mathrm{g})$ & Erucic acid $(\%)$ \\
\hline High oil & 45.21 & 24.30 & 48.93 & 10.06 \\
Low oil & 44.06 & 25.72 & 47.49 & 9.99 \\
High glucosinolate & 44.43 & 25.36 & 52.30 & 11.55 \\
Low glucosinolate & 44.24 & 25.61 & 46.93 & 9.03 \\
\hline
\end{tabular}

\section{Discussion}

Oilseed rape is a predominantly self-pollinated crop with about one-third outcrossing (Becker et al., 1992) and the Brassica species are primarily pollinated by honeybees (Williams et al., 1987). Furthermore, wind pollination is possible over distances of up to $2.5 \mathrm{~km}$ (Timmons et al., 1995). Therefore, if there are pollen parent effects on seed quality, the outcrossing under conventional field condition plays an important role for quality control. It is assumed that the seed quality like oil, protein, and glucosinolates are determined by the maternal plants, not influenced by the pollinators. To evaluate the hypothesis, oil, protein and glucosinolate (GSL) were observed in both inbreds and $F_{3}$ seeds from $F_{2}$ plants under open-pollinated (OP) and self-pollinated (SP) conditions in conventional field condition.

For glucosinolate content the low parental lines in OP showed higher contents than $\mathrm{SP}$ in glucosinolate, because there were other pollen parent lines with higher glucosinolate (GSL) content in the neighbouring plots. Therefore, this indicated that there was the pollen influence on glucosinolate content. Generally, not only $F_{3}$ seeds but also parental lines showed that the open-pollinated plant seed posses higher oil, and lower protein and glucosinolate (GSL) contents than seeds from self-pollinated plants. It indicated the pollen effects from outcrossing under conventional field condition. There were no differences in thousand seeds weight between self and open-pollinated plants seed (data not shown), and therefore the differences in contents of oil, protein and GSL in seeds were caused by the different pollination systems. 
The mean values of glucosinolate content in $F_{3}$ seeds of self-pollinated plants were higher than parental lines. The $F_{3}$ seed may get more duration time in maturity and it can better accumulate the GSL than parental lines. It indicated that there was more environmental effects on glucosinolate. In addition, the mean values of glucosinolate content between self-pollinated and open-pollinated $F_{3}$ seeds showed larger variation than the parental lines. Therefore, it can be suggested that the environmental effects on the parental seeds is smaller than on $F_{3}$ seeds.

The selection efficiency by using NIRS was observed in oil, protein, and GSL contents. It can be suggested that there were the segregation among $F_{2}$ seeds and the selections for those traits were possible for single seeds selection. It indicated that the developed calibration equations for single seed selection in oil, protein, and total GSL content can be used for individual $F_{2}$ seeds selection by NIRS. The result by Silvela et al. (1989) showed that single seed selection was found to be more effective in improving oil content than composite sample selection in maize (Zea mays L.).

The results of mean values of $\mathrm{F}_{3}$ seed from four crosses at three locations supported the response of selection among segregating $F_{2}$ seed. The higher erucic acid content was found in the bulk seed of high oil content than low oil content. The results support the hypothesis of increase oil content with high erucic acid content.

Therefore, the overall results indicated that there are influence of pollen parents in oil, protein and glucosinolate. Finally, it can be concluded that this selection among individual $F_{2}$ seeds is supporting four hypotheses: (1) the seed quality is determined by the embryo, that means by the genotype of the $F_{2}$ seed, not by the genotype of the $F_{1}$ mother plant, (2) the variation in seed quality among $F_{2}$ seeds has a sufficiently high heritability, that means environmental factors influencing differences among individual seeds on the same mother plant do not mask all genetic differences, (3) the seed quality can be reliably measured by NIRS, and (4) the seed quality in conventional trail plots can be influenced by pollinators from other plots when open-pollination seeds are harvested. 


\section{Acknowledgements}

The financial support provided by the "Gesellschaft zur Förderung der privaten deutschen Pflanzenzüchtung (GFP)" and "Deutscher Akademischer Austauschdienst (DAAD)" is gratefully acknowledged. The authors thank KWS and Saatzucht Hadmersleben for performing field tests and Norddeutsche Pflanzenzucht (NPZ) for providing the male sterile lines. Sonja Yaman and Nicole RitgenHomayounfar are gratefully acknowledged for their technical assistance.

\section{References}

Becker, H.C., C. Damgaard, and B. Karlsson. 1992. Environmental variation for outcrossing rate in rapeseed (Brassica napus). Theoretical and Applied Genetics 84:303-306.

Diepenbrock, W., and F. Grosse. 1995. Rapessed (Brassica napus L.). In: Diepenbrock, W., and H.C. Becker (eds.): Physiological Potentials for Yield Improvement of Annual Oil and Protein Crops. Advances in Plant Breeding $17: 21-53$.

Grami, B., R.J. Backer, and B.R. Stefansson. 1977. Genetics of protein and oil content in summer rape: heritability, number of effective facotors, and correlations. Candian Journal of Plant Science 5/:937-943.

Hom, N.H., A. Girke, C. Möllers, and H.C. Becker. 2003. Influence of pollen genotype on rapeseed quality - Analyses of single seeds by near-infrared reflectance spectroscopy (NIRS). Proceedings of the $11^{\text {th }}$ International Rapeseed Congress. Copenhagen, Denmark, 1:266-268.

Silvela, L., R. Rodgers, A. Barrera, and D.E. Alexander. 1989. Effect of selection intensity and population size on percentage oil in maize, Zea mays L. Theoretical and Applied Genetics 78:298-304.

Tillmann, P. 2004. www.vdlufa.de/nirs. Site last time visited 03.09.2003. 
Timmons, A.M., E.T. O’Brien, Y.M. Charters, S.J. Dubbles, and M.J. Wilkinson. 1995. Assessing the risks of wind pollination from fields of genetically modified Brassica napus ssp. oleifera. Euphytica 85:417-423.

Trautwein, E.A. 2000. Nutritional qualities of rapeseed oil. The optimization of agricultural production and the exploitation of oil an dprotein olants. 10 years of UFOP promotional measures an overview. Union for Promoting Oilseeds and Protein Plants (UFOP) Documentation, p.33.

Utz, H.F. 1997. Plabstat-Ein Computerprogramm zur statistischen Analyse von pflanzenzüchterischen Experimenten. Version $2 \mathrm{~N}$. Institute für Pflanzenzüchtung, Saatgutforschung und Populationsgenetik, Universität Stuttgart-Hohenheim. (http:/www.uni-hohenheim.de/ ipspwww/soft.html)

Velasco, L., C. Möllers, and H.C. Becker. 1999. Screening for quality traits in single seeds of rapeseed by Near-Infrared Reflectance Spectroscopy [CD-ROM]. Proceedings of the $10^{\text {th }}$ International Rapeseed Congress. Canberra, Australia.

Williams, I.H, A.P. Martin, and R.P. White. 1987. The effect of insect pollination on plant development and seed production in winter oilseed rape (Brassica napus L.). Journal Agricultural Science Cambridge 109:135-139. 


\section{Acknowledgements}

First and foremost, I would like to express my most profound gratitude to my major supervisor Prof. Dr. Heiko C. Becker for his support, guidance, and for the many critical and helpful suggestions offered throughout the course of this work. Acknowledgements are also due to Prof. Dr. Elke Pawelzik for her suggestions and comments for this dissertation as Co-referee, and Prof. Dr. Bernward Märländer for his interest to be an external examiner.

I would like to express my sincere gratitude to Dr. Christian Möllers for his review and supervision of the research project and dissertation, and Dr. Andreas Girke (NPZ) who worked at the seed-time of the project for his excellent implementation and his comments. Grateful thanks are also express to Prof. Dr. Wolfgang Link for his valuable comments and support during my study. My warmest thanks to Mrs. Sonja Yaman, Mr. Uwe Ammermann, and Mrs. Nicole Ritgen-Homayounfar for their excellent technical assistance. I also take this opportunity to express my thanks to all friends and staff who have provided assistance and encouragement, each in their own way.

The study is possible by a scholarship granted by the German Academic Exchange Service (DAAD). The support of the "DAAD" during my study is much appreciated. The "Gesellschaft zur Förderung der privaten deutschen Pflanzenzüchtung (GFP)" is acknowledged for the financial support for the research project.

I especially would like to extend my sincere thanks to Ambassadors and all the Embassy staff (German Embassy, Yangon and Myanmar Embassy, Berlin) for essential help during my study period.

U Tin Htut Oo (Director-General), Dr. Toe Aung (Deputy Director-General), U Kyi Win (Deputy-Director) and all staff of the Department of Agricultural Planning, Myanmar for their supports are acknowledged. I would like to express my sincere thanks to Rector Dr. Kyaw Than, Pro-Rector U Hla Htun, Pro-Rector Dr. Cho Cho Myint, Prof. U Han Nyunt, and Associate-Prof. Daw Khin Lay Swe and all staff of Yezin Agricultural University, Myanmar for their kindly encouragement.

Finally, I would like to pass my special thanks to my parents, U Sai Htun Hla and Daw Nang Kham Moe, and all my family, teachers and friends who always support and encourage me for the study. 


\section{Curriculum Vitae}

$\begin{array}{ll}\text { Name } & \text { Nang Hseng Hom } \\ \text { Nationality } & \text { Myanmar } \\ \text { Date of birth } & \text { 15.2.1963 } \\ \text { Place of birth } & \text { Kyaukme, Shan State, Myanmar } \\ \text { Office address } & \begin{array}{l}\text { Department of Agricultural Botany, Yezin Agricultural University, } \\ \text { 05282-Yezin, Myanmar. }\end{array} \\ \text { E-mail address } & \text { yau@cybertech.net.mm } \\ \text { Residence phone } & \text { 0095-(0)81-21239 }\end{array}$

\section{School Education}

1968-1972 Primary school (Kyanetone, Myanmar).

1972-1976 Secondary school (Kyanetone, Myanmar).

1976-1979 High secondary school (Kyanetone and Taunggyi, Myanmar).

\section{College and University Education}

1980-1982

1983-1985

1995

1995-1997

2001

2001-2004
Studied at Regional College (Biology), Mawlamyine, Myanmar.

Studied at Agricultural University, Yezin, Myanmar and graduated with Bachelor of Agriculture Sciences (B.Ag). German language course, Goethe Institute, Göttingen, Germany Postgraduate studied at Georg-August University, Göttingen, Germany; awarded Master of Tropical and Sub-Tropical Agricultural Sciences (M.Agr.Sc) in Plant Breeding.

German language course, Goethe Institute, Göttingen, Germany. Studying for obtaining Ph.D. degree at Institute of Agronomy and Plant Breeding, Georg-August University, Göttingen, Germany.

\section{Professional Career}

1985-1989

Rural development and extension village manager, Mawlamyine and Taunggyi townships at the Ministry of Agricultural and Irrigation, Myanmar.

1989-2004

Teaching staff, Department of Agricultural Botany, Yezin

Agricultural University, Yezin, Myanmar. 